\title{
Test Well DO-CE 88 at Cambridge, Dorchester County, Maryland
}

\author{
By HENRY TRAPP, JR., LEROY L. KNOBEL, \\ HAROLD MEISLER, and P. PATRICK LEAHY
}

A summary of information derived from a test well drilled to basement on the Delmarva Peninsula, Atlantic Coastal Plain 


\section{UNITED STATES DEPARTMENT OF THE INTERIOR WILLIAM P. CLARK, Secretary \\ GEOLOGICAL SURVEY \\ Dallas L. Peck, Director

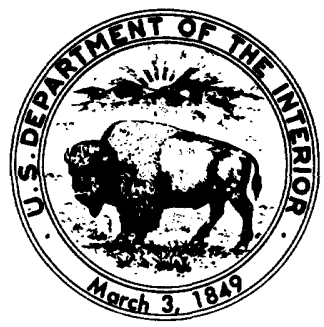

UNITED STATES GOVERNMENT PRINTING OFFICE: 1984

For sale by Distribution Branch

Text Products Section

U.S. Geological Survey

604 South Pickett Street

Alexandria, Virginia 22304

Library of Congress Cataloging in Publication Data

Main entry under title:

Test well DO-CE 88 at Cambridge, Dorchester County, Maryland.

(Geological Survey water-supply paper ; 2229)

Bibliography: $p$.

Supt. of Docs. no.: I 19.13:2229

1. Water, Underground-Maryland-Cambridge.

2. Geology-Maryland-Cambridge.

3. Borings-Maryland-Cambridge. I. Trapp, Henry, Jr.

II. Title: Test well D.O.-C.E. eighty eight at Cambridge,

Dorchester County, Maryland. III. Series.

GB1025.M3T47 $1983 \quad 553.7^{\prime} 9^{\prime} 0975227 \quad 83-600058$ 


\title{
CONTENTS
}

\author{
Abstract 1 \\ Introduction 1 \\ Purpose and scope 1 \\ Geographic and geologic setting 1 \\ Acknowledgments 1 \\ Well construction 3 \\ Drilling and casing procedures 3 \\ Development 3 \\ Plugback, perforation, and redevelopment 3 \\ Hydrogeology 4 \\ Drill cuttings 4 \\ Geophysical logs 4 \\ Cores 18 \\ Coring methods 18 \\ Lithologic descriptions of cores 18 \\ Paleontology 18 \\ Hydraulic analysis 18 \\ Sieve analysis 22 \\ X-ray analysis of clay fractions 22 \\ Heavy mineral and feldspar identification 23 \\ Lithologic log 24 \\ Aquifer tests 24 \\ Interpretation of temperature-corrected drawdown 25
}

Heads 36

Geochemistry 38

Water analyses 38

Water from cores 39

Water produced from well 39

Cation exchange capacities and concentrations of exchangeable cations 43

Summary and conclusions 45

Selected references 45

Metric conversion factors 48

\section{FIGURES}

1. Map showing location of U.S. Geological Survey test well DO-CE 882 2-5. Geophysical logs showing:

2. Dual induction with spontaneous potential and gamma-ray logs, screened and perforated zones, and formation tops 5

3. Simultaneous compensated neutron-formation density (expressed as porosity), with gamma-ray and caliper logs, screened and perforated zones, and formation tops 9

4. Borehole-compensated sonic $\log$, with gamma-ray and caliper logs, screened and perforated zones, and formation tops 13

5. Temperature log 18 
6-11. Graphs showing:

6. Grain-size distribution of core samples 27

7. Computation of transmissivity of screened zone 3,188 to 3,218 ft below kelly-bushing datum 28

8. Temperature profiles during pumping test of screened zone 3,188 to $3,218 \mathrm{ft}$ below kelly-bushing datum 29

9. Head and density profile 37

10. Variation in concentration of major cations with depth 41

11. Variation in concentration of major anions and silica with depth 42

12. Durov diagram showing the hydrochemical facies of ground water from test well DO-CE 88 and other nearby wells 44

13. Graph showing cation exchange capacities and exchangeable cation concentrations 46

\section{TABLES}

1. Summary of recompletion attempts 4

2. Stratigraphy at test well DO-CE 8817

3. Core data 19

4-12. Fossil species identified from core samples:
4. $130-140$ feet 23
5. $150-152$ feet 23
6. $340-343$ feet 24
7. $590-592$ feet 26
8. $730-732$ feet 27
9. $912-915$ feet 28
10. $2,900-2,909$ feet 29
11. $3,008-3,010.5$ feet 30
12. $3,110-3,112$ feet 30

13. Heavy minerals and feldspars in selected core samples 30

14. Interpretative lithologic description, well DO-CE 8831

15. Transmissivities, hydraulic conductivities, and intrinsic permeabilities based on aquifer-test analyses 36

16. Summary of fluid-head measurements 36

17. Principal dissolved chemical constituents of water samples from cores in U.S. Geological Survey test well DO-CE 88 and of selected other samples 38

18. Chemical analyses of wellhead water samples 39

19. Cation exchange capacities from core samples, in milliequivalents per 100 grams 43

20. Exchangeable cations from core samples, in milligrams per gram 45 


\title{
Test Well DO-CE 88 at Cambridge, Dorchester County, Maryland
}

\author{
By Henry Trapp, Jr., LeRoy L. Knobel, Harold Meisler, and P. Patrick Leahy
}

\begin{abstract}
Test well DO-CE 88 at Cambridge, Maryland, penetrated 3,299 feet of unconsolidated Quaternary, Tertiary and Cretaceous sediments and bottomed in quartz-monzonite gneiss. The well was drilled to provide data for a study of the aquifer system of the northern Atlantic Coastal Plain. Twentyone core samples were collected. Six sand zones were tested for aquifer properties and sampled for ground-water chemistry. Point-water heads were measured at seven depths. Environmental heads (which ranged from -18.33 to +44.16 feet relative to sea level) indicate an upward component of flow. A temperature log showed a maximum temperature of 41.9 degrees Celsius and a mean temperature gradient of 0.00838 degrees Celsius per foot.

The water analyses delineated the freshwater-saltwater transition zone between 2,650 and 3,100 feet. The ground water changes progressively downward from a sodium bicarbonate to a sodium chloride character. Clays in the analyzed core samples belong to the montmorillonite and kaolinite groups, and mean cation exchange capacity ranged from 8.3 to 38.9 milliequivalents per 100 grams.

Vertical and horizontal hydraulic conductivities measured in cores ranged from $1.5 \times 10^{-6}$ to 1.3 feet per day and from $7.3 \times 10^{-6}$ to 1.3 feet per day, respectively, but the most permeable sands were not cored. Porosity was 1.5 percent in the quartz monzonite bedrock and ranged from 22.4 to 41 percent in the overlying sediments. Transmissivities from aquifer tests ranged from 25 to 850 feet squared per day; horizontal hydraulic conductivities ranged from 2.5 to 85 feet squared per day, and intrinsic permeabilities ranged from 0.8 to 23 micrometers squared.

Fossils identified in core samples include palynomorphs, dinoflagellates, and foraminifers.
\end{abstract}

\section{INTRODUCTION}

\section{Purpose and Scope}

The U.S. Geological Survey has begun a comprehensive study to define the geology, hydrology, and geochemistry of the northern Atlantic Coastal Plain aquifer system. As part of this study, a test well was drilled to basement near Cambridge, Md., to meet the following objectives:
1. To determine the chemical character of the ground water and the position of the freshwater-saltwater transition zone at a location where control was needed for regional definition.

2. To determine the lithology, stratigraphy, and thickness of the Coastal-Plain sediments and to define the aquifers and confining beds.

3. To obtain quantitative data on aquifer and confiningbed hydraulic properties and on hydraulic heads.

4. To determine the capacity of the clays in the sedimentary section to exchange ions with the ground water.

5. To discover the nature of the basement rock.

\section{Geographic and Geologic Setting}

Test well DO-CE 88 is located near Cambridge, Dorchester County, Md., on the Delmarva Peninsula (fig. 1). It was drilled on the south bank of the Choptank River, on the grounds of the Eastern Shore Hospital Center, at latitude $38^{\circ} 34^{\prime} 01^{\prime \prime} \mathrm{N}$., longitude $76^{\circ} 03^{\prime} 20^{\prime \prime} \mathrm{W}$.

The Northern Atlantic Coastal Plain study area extends from New York through North Carolina and offshore to the Continental Slope. The Coastal Plain sediments form a wedge that thickens onshore from a feather edge at the Fall Line to 8,000 ft along the coast of Maryland and 10,000 ft in North Carolina. The beds dip gently seaward. The sediments are both marine and nonmarine in origin and range in age from Jurassic to Holocene. They consist largely of sand, silt, and clay and are unconsolidated except for thin cemented layers and the more deeply buried sediments. The marine sediments include significant amounts of glauconite, shell material, calcareous clay, and limestone.

\section{Acknowledgments}

The authors acknowledge Harry J. Hansen of the Maryland Geological Survey for assistance in obtaining permission to drill, preparing contıact specifications, and interpreting data. Jonathan Edwards, Jr., of the 

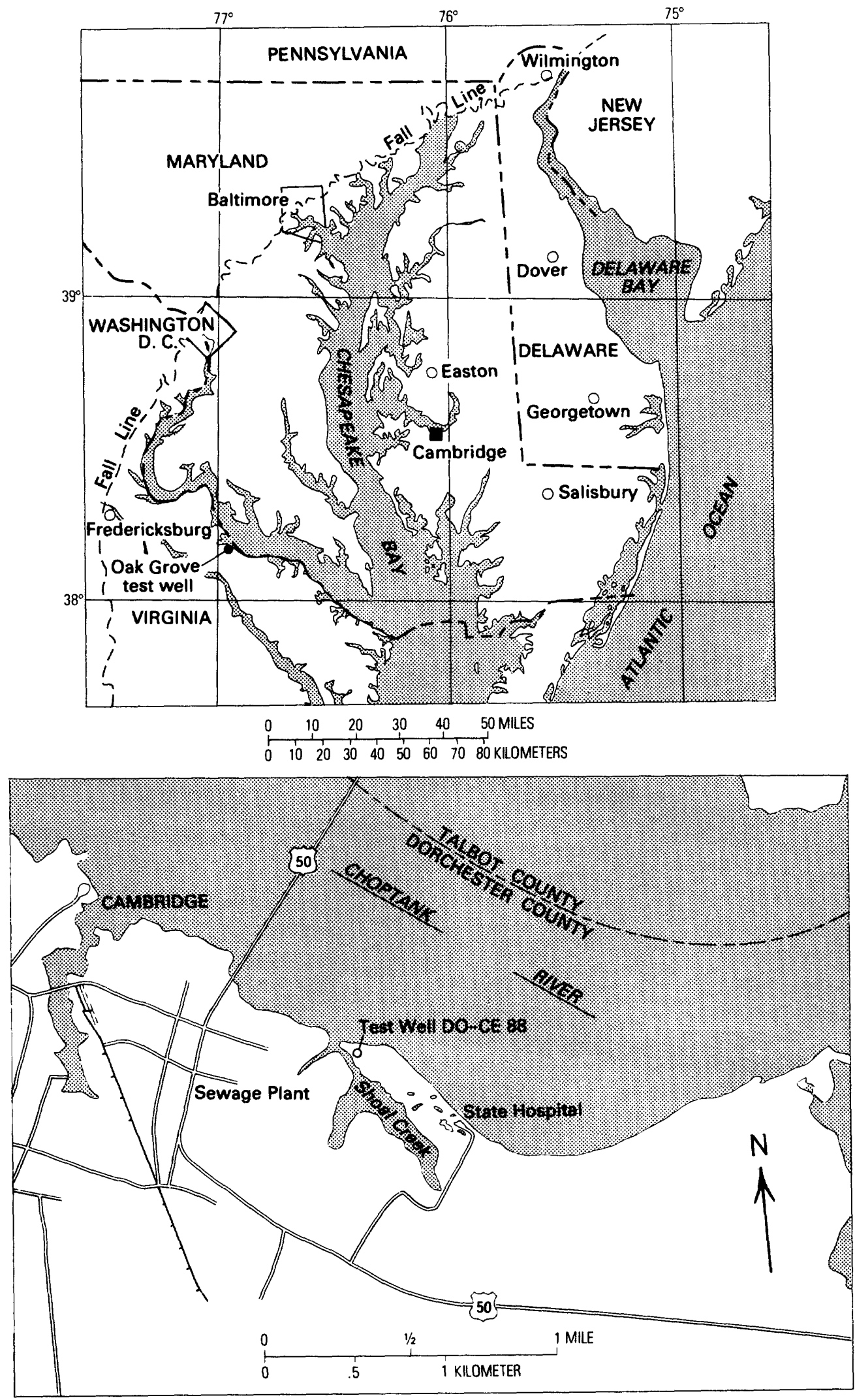

Figure 1. Location of U.S. Geological Survey test well DO-CE 88. 
Maryland Geological Survey, described the petrology of the basement cores. Lowell Douglas and Pa Ho Hsu of Cook College, Rutgers University, provided laboratory space, X-ray equipment, and technical assistance for determination of clay mineralogy. Gilbert J. Brenner, State University of New York at New Paltz, identified fossil pollen in core samples and assigned them to pollentime zonations. William H. Abbott, of Mobil Exploration and Producing Services, identified diatoms in the Tertiary cores and assigned them to time zones. Richard K. Olsson, Rutgers University, identified foraminifers in cores and assigned ages and paleoenvironments. Wilson S. McClung, Virginia Polytechnic Institute and State University, ran a temperature log of the well. Dr. H. M. English, superintendent of the Eastern Shore Hospital Center, granted permission to use the hospital grounds. David Leap, assistant superintendent, allowed access to the drill site, and Rodney Hurley, maintenance supervisor, provided logistical support. Lois Lane, of the University of Maryland, Environmental and Estuarine Studies, provided analytical support during water-sample collection. Lucy McCartan, U.S. Geological Survey, arranged for micropaleontologic studies of the cores and made helpful suggestions on presentation of the data. James P. Owens, U.S. Geological Survey, identified minerals in sedimentary-rock cores. Richard $Z$. Poore, U.S. Geological Survey, dated cores using planktonic foraminifers, and Lucy Edwards, U.S. Geological Survey, did the same by means of dinoflagellates. Frank T. Manheim, U.S. Geological Survey, provided core-squeezing equipment and consultation on sampling techniques. Candice M. Lane, U.S. Geological Survey, determined the water content and its chloride concentration for the bedrock core. J. Glen Blevins, U.S. Geological Survey, retired, coordinated drilling, coring, wellconstruction, and testing activities at the drill site. The authors wish to acknowledge the contributions of the following U.S. Geological Survey personnel for assisting during the drilling and testing phases of the operation: William B. Fleck, Franceska Wilde-Katz, Don A. Vroblesky, Daniel J. Phelan, Rene DeLisle, and Andrew A. Meng.

\section{WELL CONSTRUCTION}

\section{Drilling and Casing Procedures}

The Layne-Atlantic Company, ${ }^{1}$ Norfolk, Va., drilled the test well by means of the hydraulic-rotary method. Datum for the well was established as the kelly bushing (KB), $5 \mathrm{ft}$ above land surface, or $9.42 \mathrm{ft}$ above

'The use of brand or company names in this report is for identification purposes only and does not constitute endorsement by the U.S. Geological Survey. sea level. The bottom of the 12 -in. diameter surface casing was set and grouted at $108 \mathrm{ft}$ below the datum. Softformation $83 / 4$-in. drill bits, with provision for wire-line coring, were used from the base of the surface casing to the total depth of $3,337 \mathrm{ft}$. Commercially prepared mud, mixed with freshwater, was used in the drilling. Cuttings samples were collected at $10-\mathrm{ft}$ intervals. Wireline cores, up to $10 \mathrm{ft}$ in length but usually shorter, were cut at intervals specified by the Survey's representative. Downhole rather than sidewall cores were specified in order to minimize contamination of the core samples by drilling mud. The contractor found it expedient to core, rather than drill, in bedrock (quartz monzonite gneiss), which was encountered at 3,304 ft. Geophysical logs were run at the total depth of $3,337 \mathrm{ft}$.

The well was plugged with cement from the total depth to $3,250 \mathrm{ft}$. Four-inch steel casing was set to 3,178 $\mathrm{ft}$ and pressure-grouted. A 4-in. telescope-size stainlesssteel screen having a 0.015 -in. slot was emplaced between 3,188 and $3,218 \mathrm{ft}$; blank pipe extended upward into the 4-in. casing.

\section{Development}

The well was developed by airlift for about 12 hours. An electric submersible pump was used for the aquifer test and sampling of the 3,188- to 3,218-ft zone.

Upon completion of testing and sampling of the 3,188- to 3,218-ft zone, the drill rig was replaced by a light workover rig, capable only of hoisting and lowering, for the redevelopment and testing phase.

\section{Plugback, Perforation, and Redevelopment}

The well was plugged back and the casing jetperforated eight times in order to obtain heads, specific capacities, and water-quality data from successively shallower sand zones. These eight intervals were selected largely in the freshwater-saltwater zone of transition as well as in the deeper freshwater-bearing zones, using geophysical logs to indicate the sections having the highest effective porosity. The intended procedure was:

1. Seal off the previously developed zone and backfill to just below the next zone with sand, gravel, and cement.

2. After the cement is set, pressure-test for leaks. If a leak is indicated, reseal by dropping cement-filled bottles down the well, breaking the bottles, and tamping them with a pipe. Allow cement to set, retest, and repeat if necessary.

3. Sound top of new plug with Survey logging unit and run gamma-ray log a short section through the casing, including the prospective new zone to be per- 
forated. Correlate the new section of gamma-ray log with the Schlumberger geophysical logs and adjust the interval to the Survey logger's measurements as required.

4. Jet-perforate the interval using the Survey logger. (Gearhart Industries, Inc., materials and methods were used.)

5. Set a 4-in., telescope-size, stainless-steel screen ( $10 \mathrm{ft}$ long) inside the casing opposite the perforations by means of the rig. A tailpipe, equal in length to the interval between the base of the perforations and the top of the plug, is attached to the bottom of the screen in order to position it.

6. Redevelop the well using an air compressor, conduct an aquifer test, and collect a water sample.

7. Repeat steps 1-6 as required.

Recompletion proceeded with difficulty. Plugs frequently leaked and had to be resealed. The perforating charges appear to have torn large holes in the casing at least once, as evidenced by chunks of carbonized wood, up to $11 / 4$ in. in diameter, blown out of the well during redevelopment by compressed air. Attempts to set screens opposite perforations were unsuccessful, either because the perforating process roughened or deformed the inside surface of the casing or because mud and aquifer material entered the casing through the perforations, impeding emplacement of the screens. The rig used during redevelopment was incapable of cleaning out or deburring the inside of the casing after perforation.

Five of the eight perforated zones listed in table 1 were developed to the point where a water sample was collected and the head measured.

\section{HYDROGEOLOGY}

A summary of the stratigraphy at the well site is shown in table 2 .

\section{Drill Cuttings}

Samples of drill cuttings were collected at $10-\mathrm{ft}$ depth intervals from the ditch leading from the conductor pipe on the well to the mud pits, without correction for sample lag.

\section{Geophysical Logs}

The Survey ran gamma-ray and multipoint electric logs at a drilling depth of 2,900 ft. These logs (not shown) were used in the preliminary definition of lithologic units. The spontaneous-potential log was especially useful for preliminary calculations of formation-water resistivity. These calculations, together with chloride measurements on water squeezed from cores, served as guides for the selection of zones to be perforated and sampled. The water resistivities calculated from this spontaneouspotential log correlate well with the freshwater-saltwater interface profile established through chloride determinations of water samples.

Schlumberger Limited ran dual-induction, gammaray, spontaneous-potential, caliper, compensated neutronformation density, and sonic logs to total depth (figs. 2-4). These logs were useful for the delineation of lithologic units and provide a continuous record of porosity values.

Table 1. Summary of recompletion attempts

\begin{tabular}{|c|c|c|c|c|c|}
\hline $\begin{array}{l}\text { Perforated interval } \\
\text { (ft below KB') }\end{array}$ & $\begin{array}{l}\text { Date } \\
\text { perforated } \\
(1981)\end{array}$ & $\begin{array}{l}\text { Plugback depth } \\
\text { (ft below KB) }\end{array}$ & Shots & $\begin{array}{c}\text { Screen } \\
\text { (ft below KB) }\end{array}$ & Remarks \\
\hline $2,834-2,844 \ldots$ & Mar. 18 & 2,939 & 40 & None & Flowed. \\
\hline $2,649-2,655.6 \cdots$ & Apr. 14 & 2,667 & 26 & None & Flowed. \\
\hline $2,278.4-2,288.4-\cdots$ & May 26 & About 2,325 & 41 & None & Flowed. \\
\hline $2,008.4-2,018.4 \ldots$ & June 10 & About 2,055 & 41 & $\begin{array}{l}\text { Abandoned, placement not } \\
\text { checked with logger }\end{array}$ & Could not be developed. \\
\hline 1,822.4-1,832.4 ---- & June 16 & About 1,865 & 42 & None & Pumped turbid water. \\
\hline 1,605.4-1,615.4 - & July 7 & About 1,655 & 42 & $\begin{array}{l}\text { About } 1,515-1,525(0.010 \text { slot }) \\
\text { recovered }\end{array}$ & $\begin{array}{l}\text { Could not be developed; screen } \\
\text { set too high. }\end{array}$ \\
\hline 1,469.4-1,479.4 - & July 21 & About 1,520 & 21 & $\begin{array}{l}\text { About } 1,456-1,466(0.010 \text { slot }) \\
\text { abandoned }\end{array}$ & $\begin{array}{l}\text { Could not be developed; screen } \\
\text { set too high. }\end{array}$ \\
\hline $1,422.4-1,432.4 \ldots$ & July 28 & 1,460 & 24 & None & Pumped turbid water. \\
\hline
\end{tabular}

${ }^{1} \mathrm{~KB}=$ kelly bushing, which was $5 \mathrm{ft}$ above land surface or $9.42 \mathrm{ft}$ above sea level. 
Altitude: Kelly bushing: 9.42 feet; Ground: 4.42 feet

Depth-Logger: 3,337 feet

Casing-Logger: 12 inches at 108 feet

Bit size: $83 / 4$ inches

Mud resistivity: $3.80 \mathrm{ohm}$-meters at $20.6^{\circ} \mathrm{C}$

Mud filtrate resistivity: $2.85 \mathrm{ohm}$-meters at $20.6^{\circ} \mathrm{C}$

Mud cake resistivity: $5.70 \mathrm{ohm}$-meters at $20.6^{\circ} \mathrm{C}$

Mud resistivity at bottom temperature: $2.55 \mathrm{ohm}$-meters at $41.1^{\circ} \mathrm{C}$

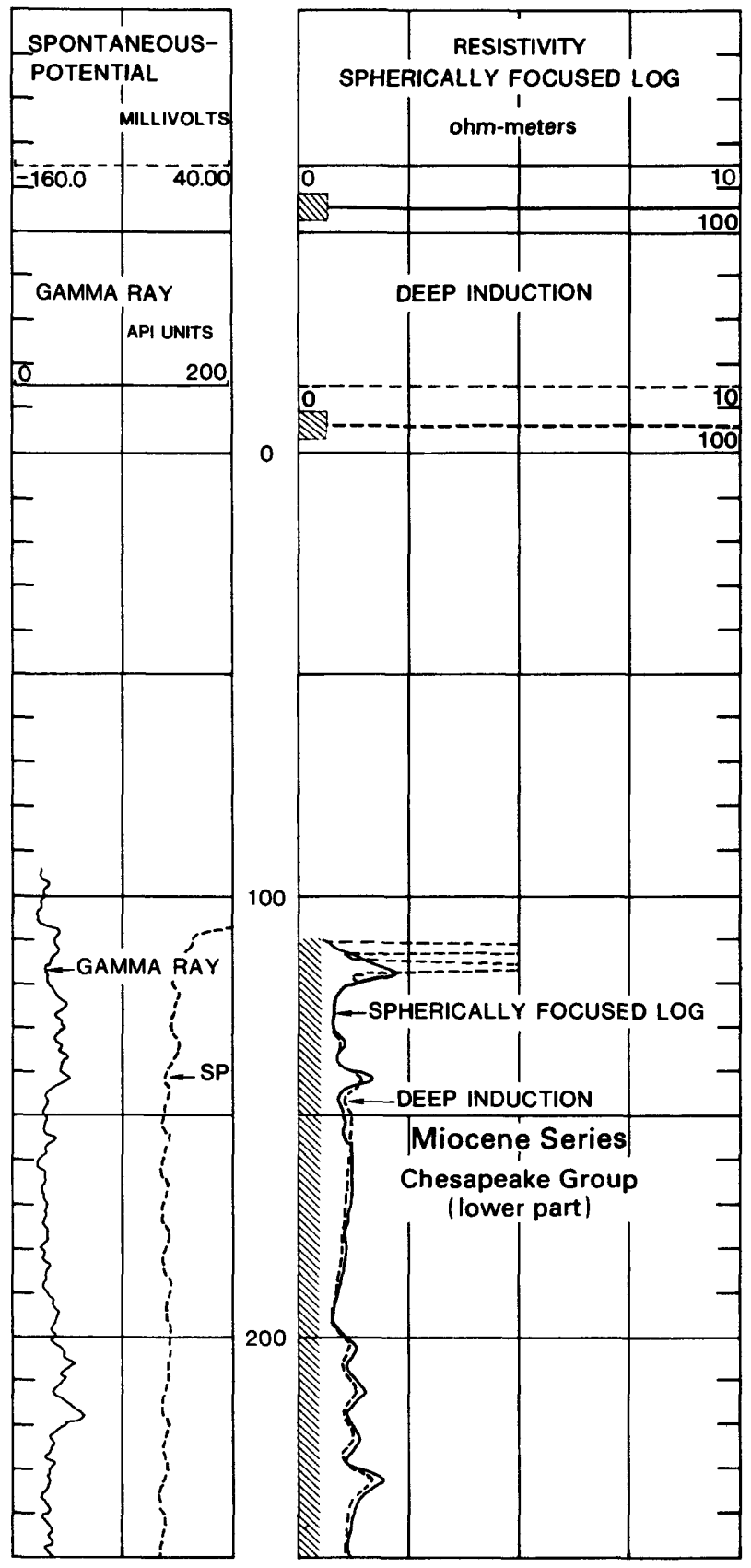

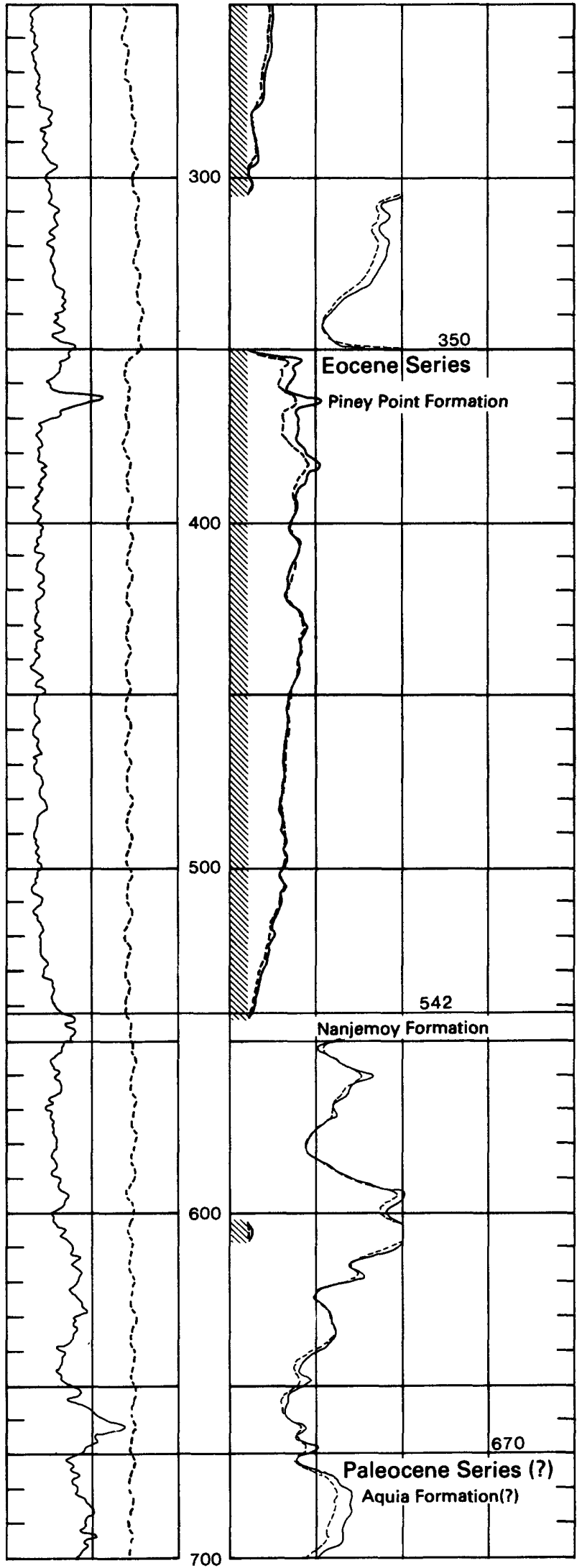

700

Figure 2. Dual induction with spontaneous potential and gamma-ray logs, screened and perforated zones, and formation tops. 

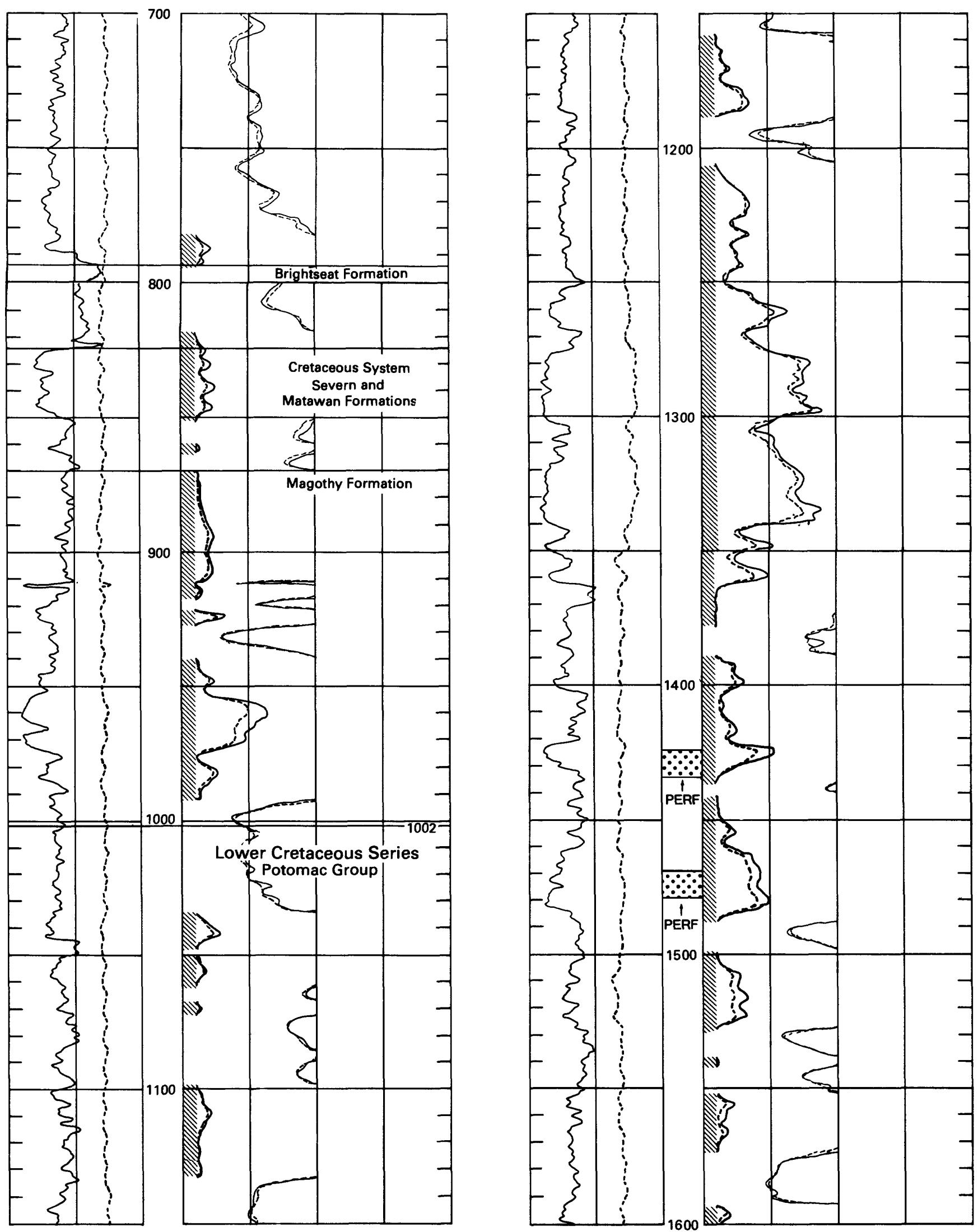

Figure 2. Dual induction with spontaneous potential and gamma-ray logs, screened and perforated zones, and formation topsContinued. 

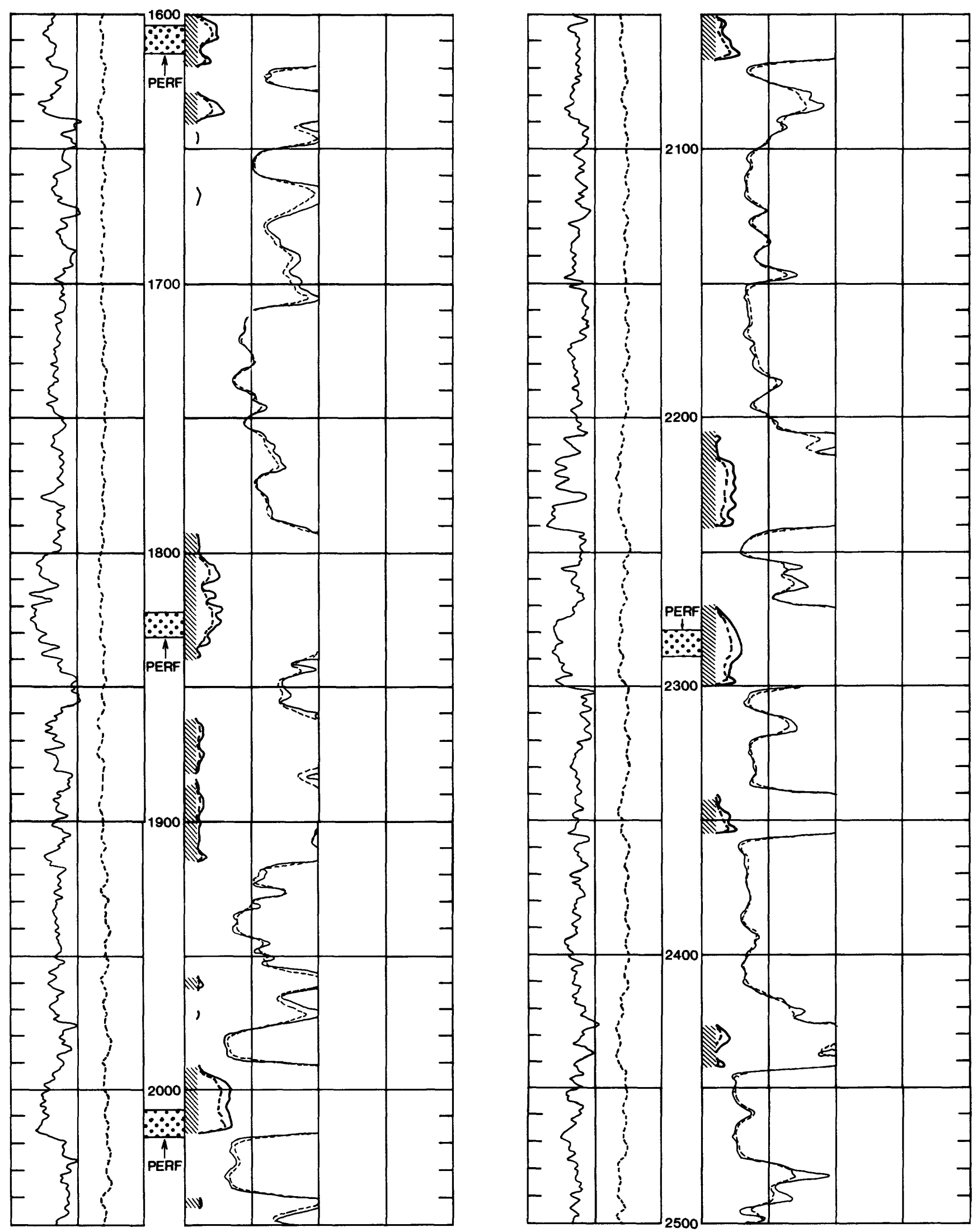

Figure 2. Dual induction with spontaneous potential and gamma-ray logs, screened and perforated zones, and formation topsContinued. 

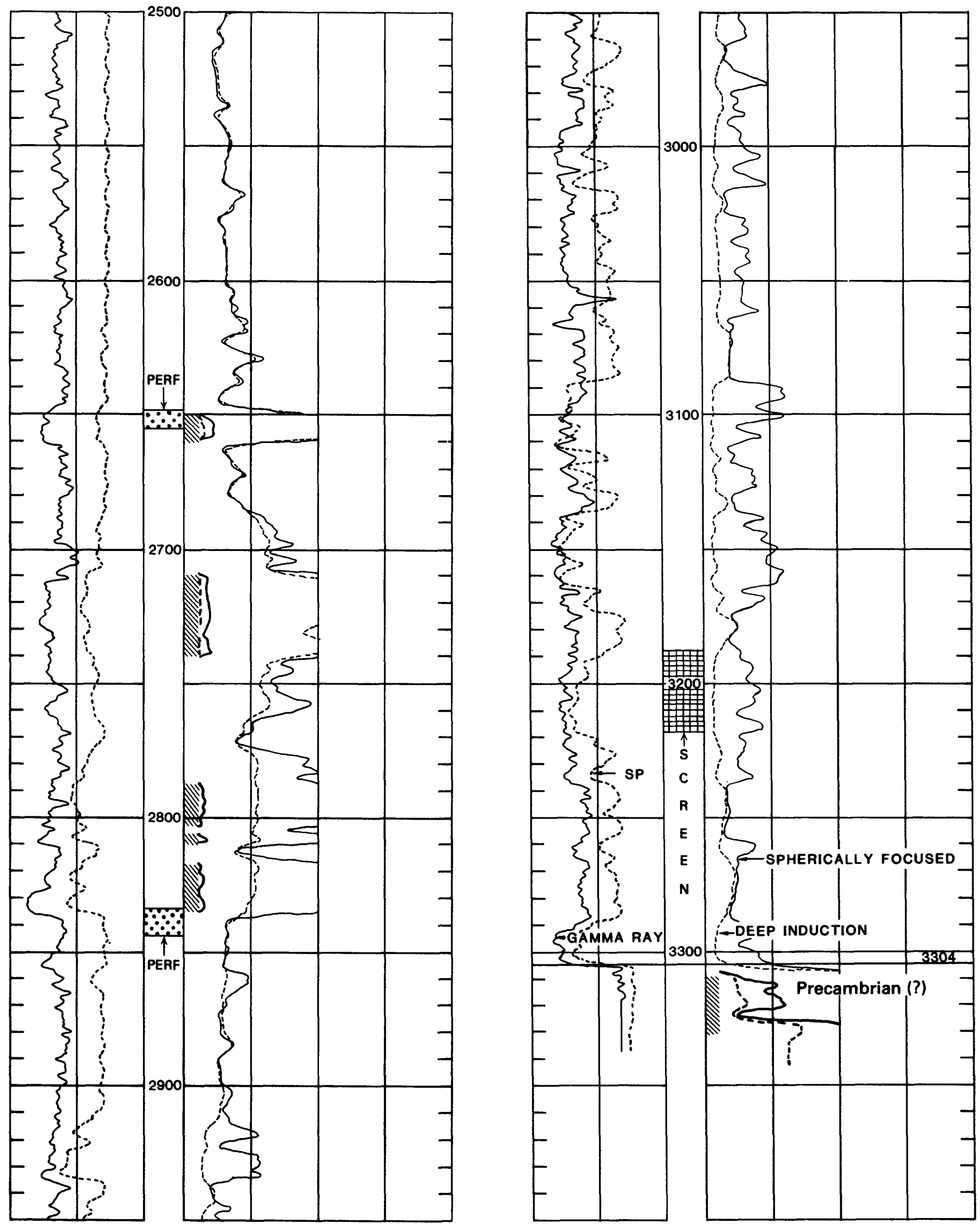

Figure 2. Dual induction with spontaneous potential and gamma-ray logs, screened and perforated zones, and formation topsContinued. 
Altitude: Kelly bushing: 9.42 feet; Ground: 4.42 feet

Depth-Logger: 3,337 feet

Casing-Logger: 12 inches at 108 feet

Bit size: $8 \% / 4$ inches

Mud resistivity: $3.80 \mathrm{ohm}$-meters at $20.6^{\circ} \mathrm{C}$

Mud filtrate resistivity: 2.85 ohm-meters at $20.6^{\circ} \mathrm{C}$

Mud cake resistivity: $\mathbf{5 . 7 0}$ ohm-meters at $20.6^{\circ} \mathrm{C}$

Mud resistivity at bottom temperature: $2.55 \mathrm{ohm}$-meters at $41.1^{\circ} \mathrm{C}$
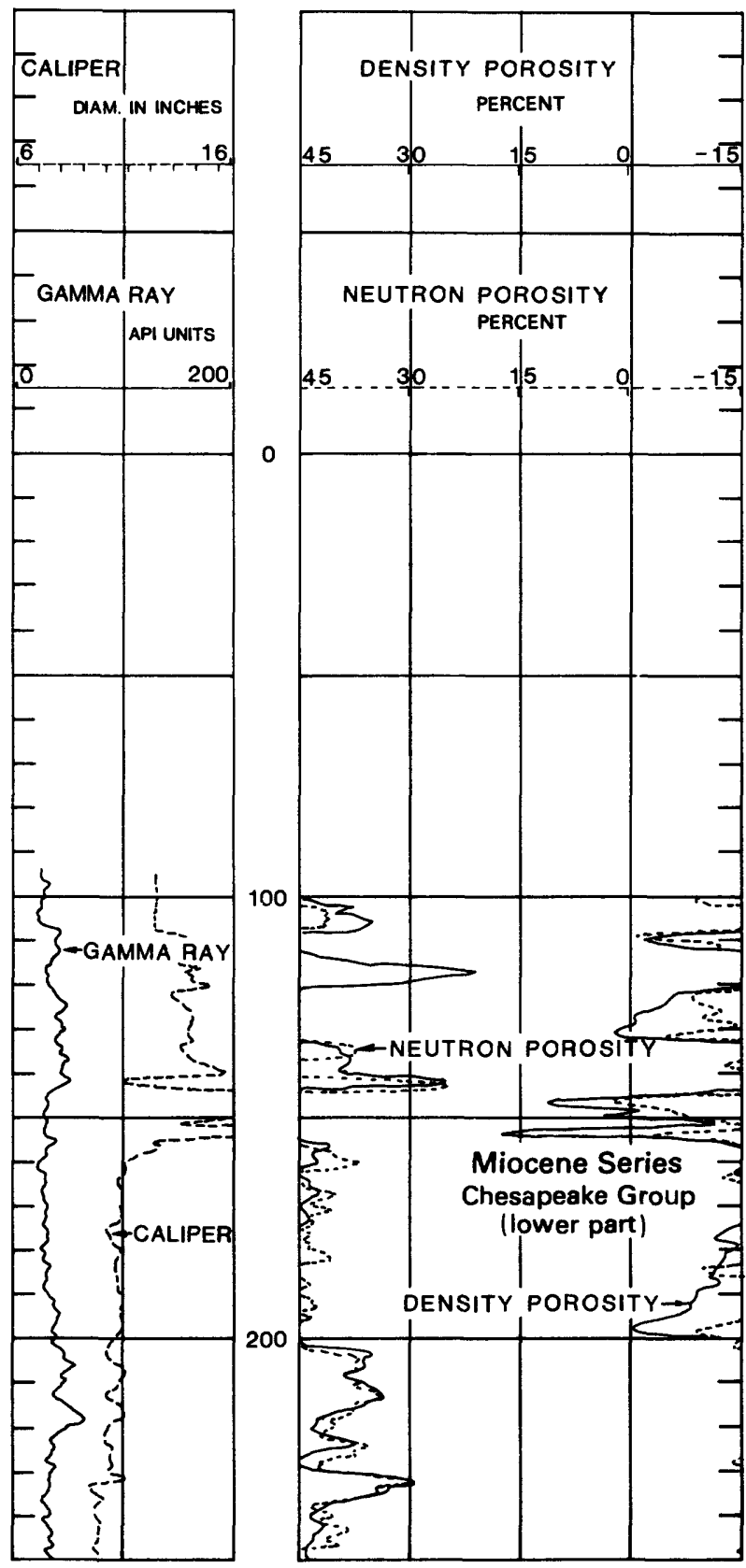

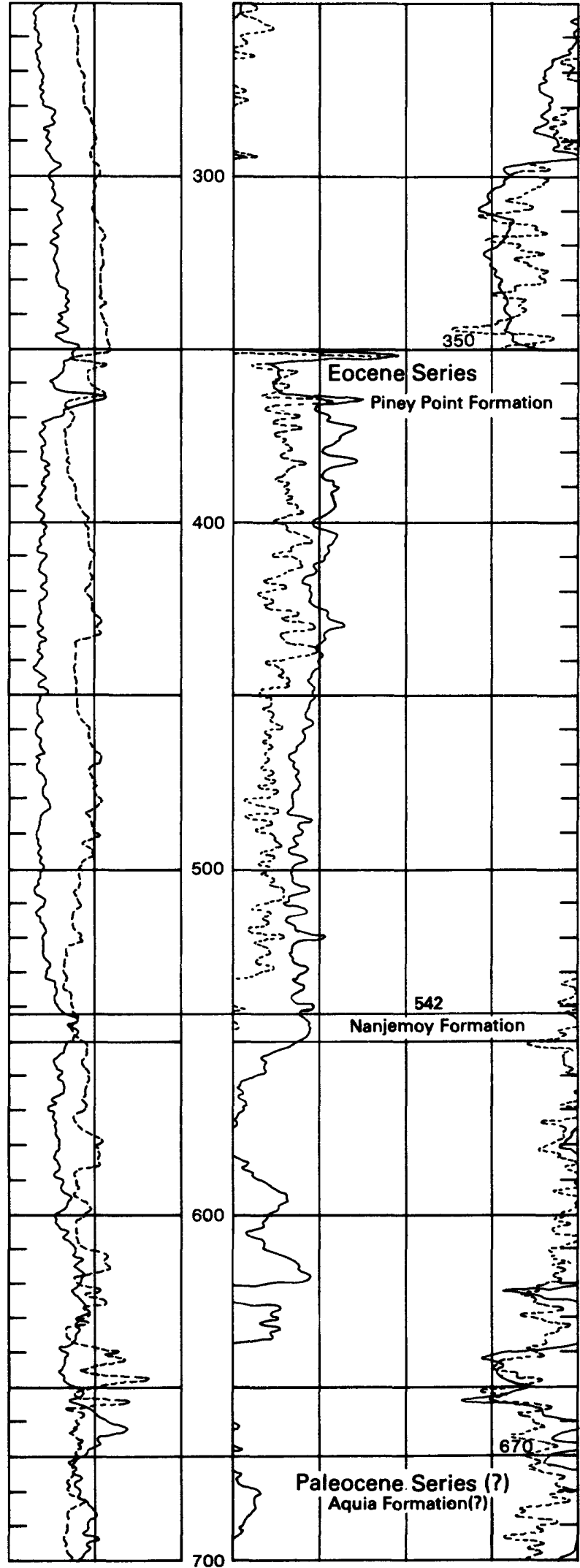

Figure 3. Simultaneous compensated neutron-formation density (expressed as porosity), with gamma-ray and caliper logs, screened and perforated zones, and formation tops. 

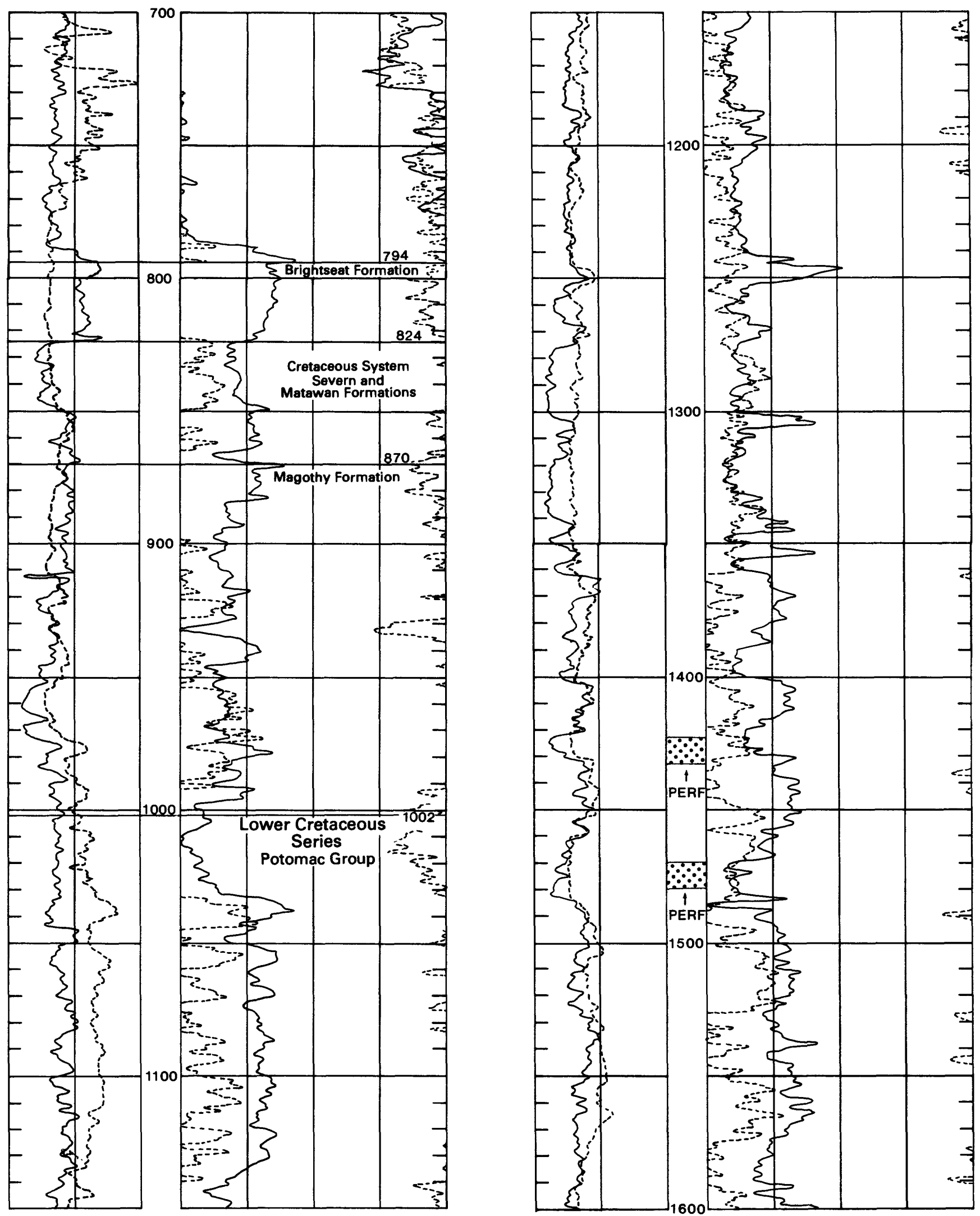

Figure 3. Simultaneous compensated neutron-formation density (expressed as porosity), with gamma-ray and caliper logs, screened and perforated zones, and formation tops-Continued. 

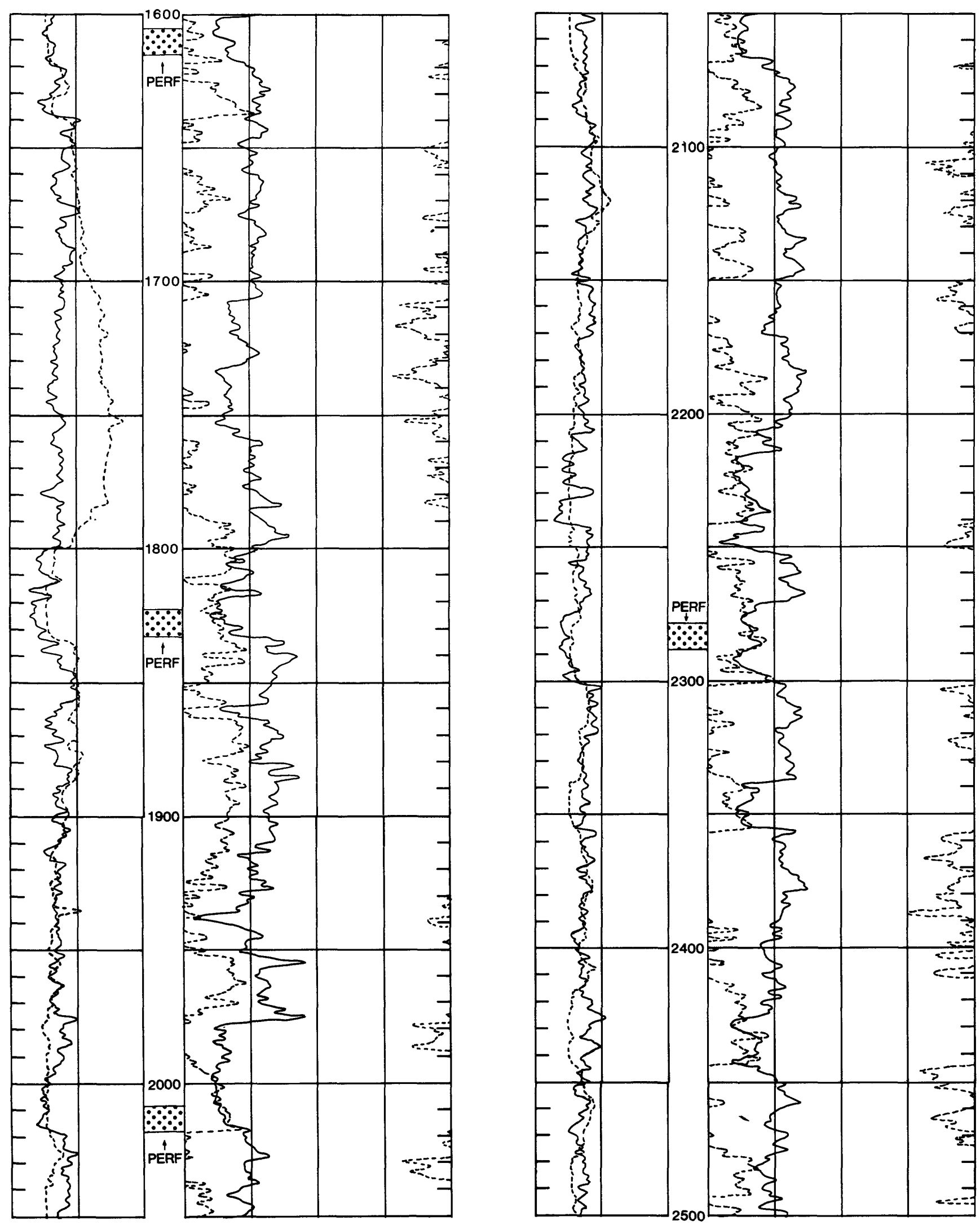

Figure 3. Simultaneous compensated neutron-formation density (expressed as porosity), with gamma-ray and caliper logs, screened and perforated zones, and formation tops-Continued. 

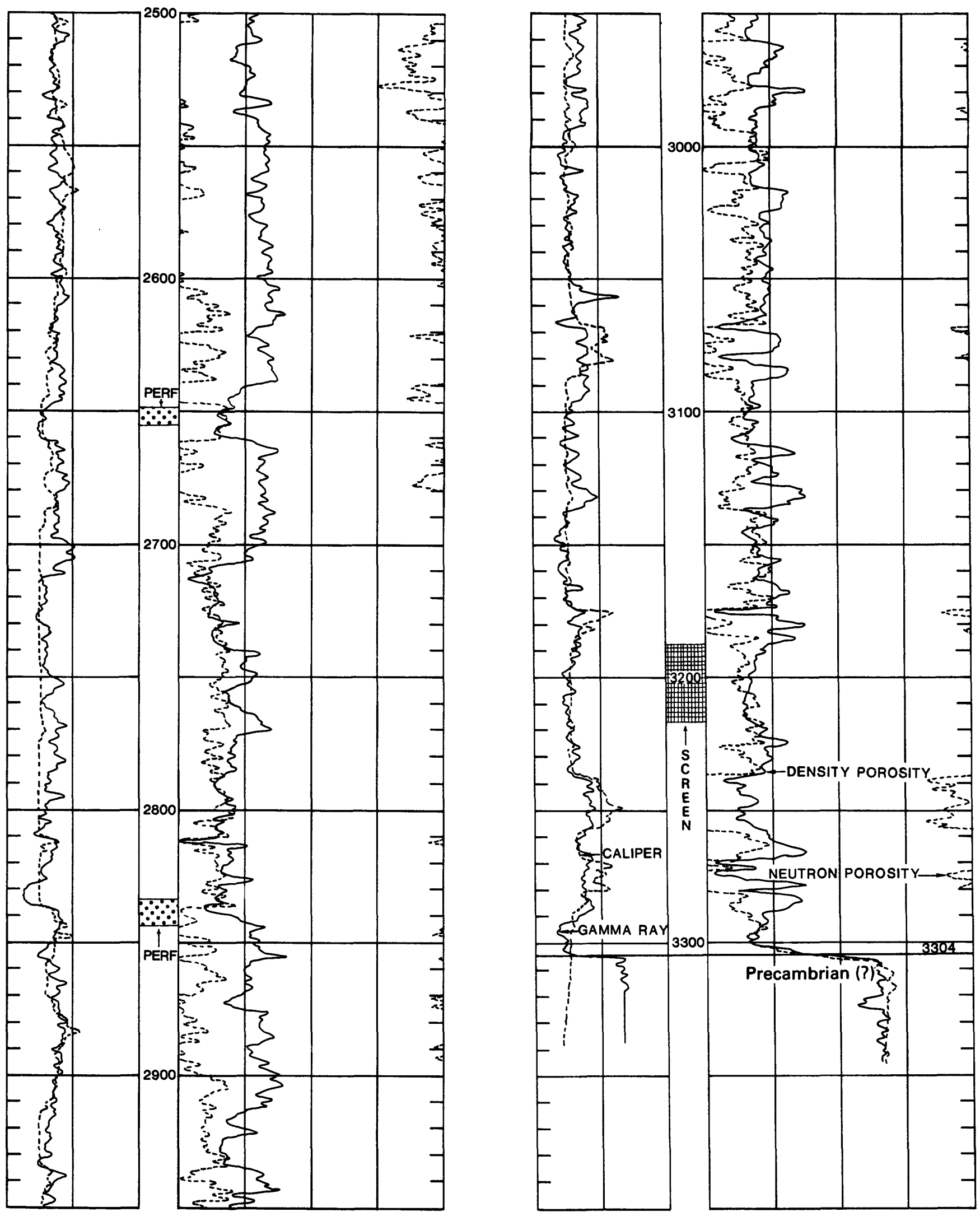

Figure 3. Simultaneous compensated neutron-formation density (expressed as porosity), with gamma-ray and caliper logs, screened and perforated zones, and formation tops-Continued. 
Altitude: Kelly bushing: 9.42 feet; Ground: 4.42 feet

Depth-Logger: 3,337 feet

Casing-Logger: 12 inches at 108 feet

Bit size: $83 / 4$ inches

Mud resistivity: $3.80 \mathrm{ohm}$-meters at $20.6^{\circ} \mathrm{C}$

Mud filtrate resistivity: $2.85 \mathrm{ohm}$-meters at $20.6^{\circ} \mathrm{C}$

Mud cake resistivity: $5.70 \mathrm{ohm}$-meters at $20.6^{\circ} \mathrm{C}$

Mud resistivity at bottom temperature: 2.55 ohm-meters at $41.1^{\circ} \mathrm{C}$
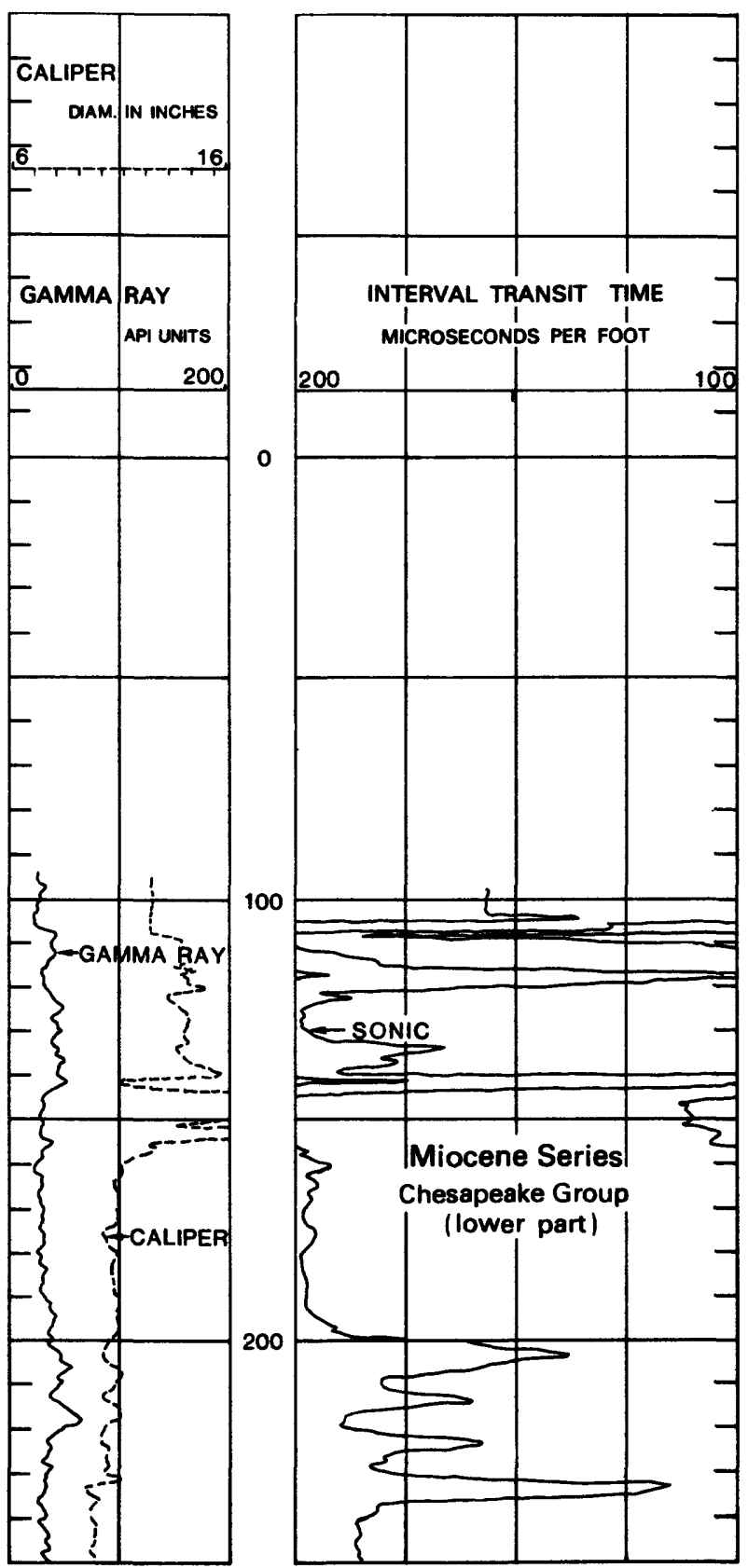

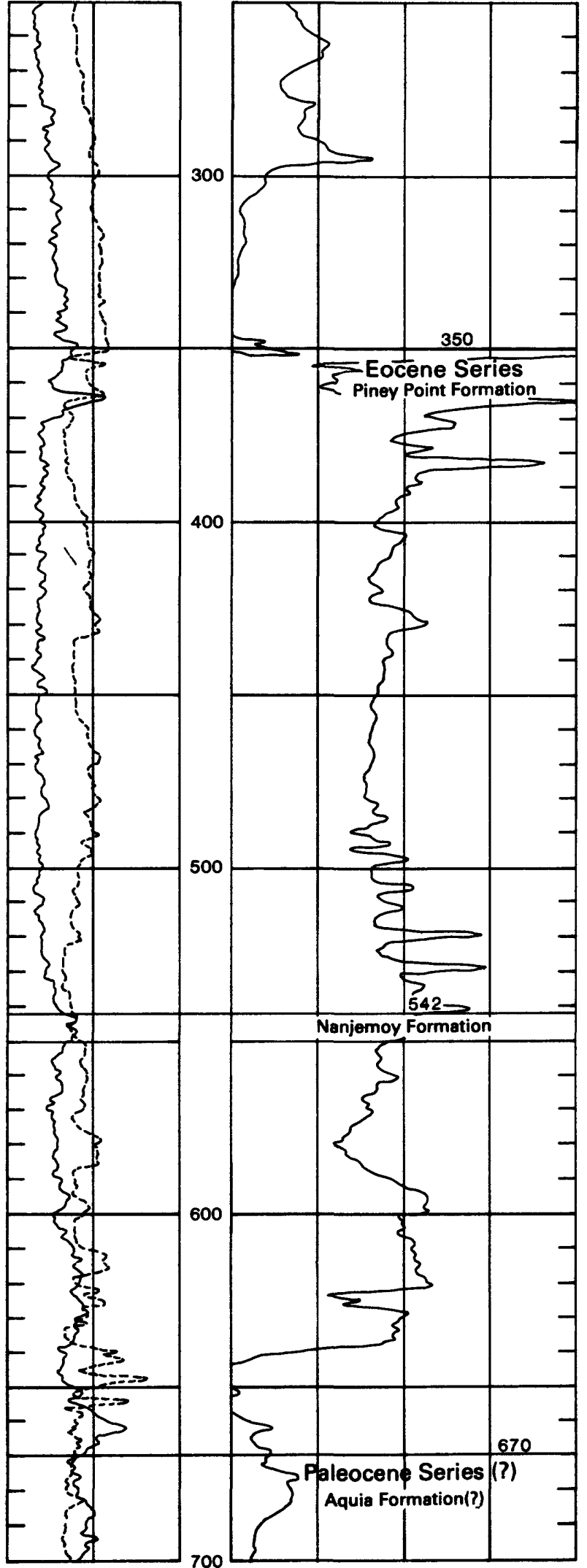

Figure 4. Borehole-compensated sonic log, with gamma-ray and caliper logs, screened and perforated zones, and formation tops. 

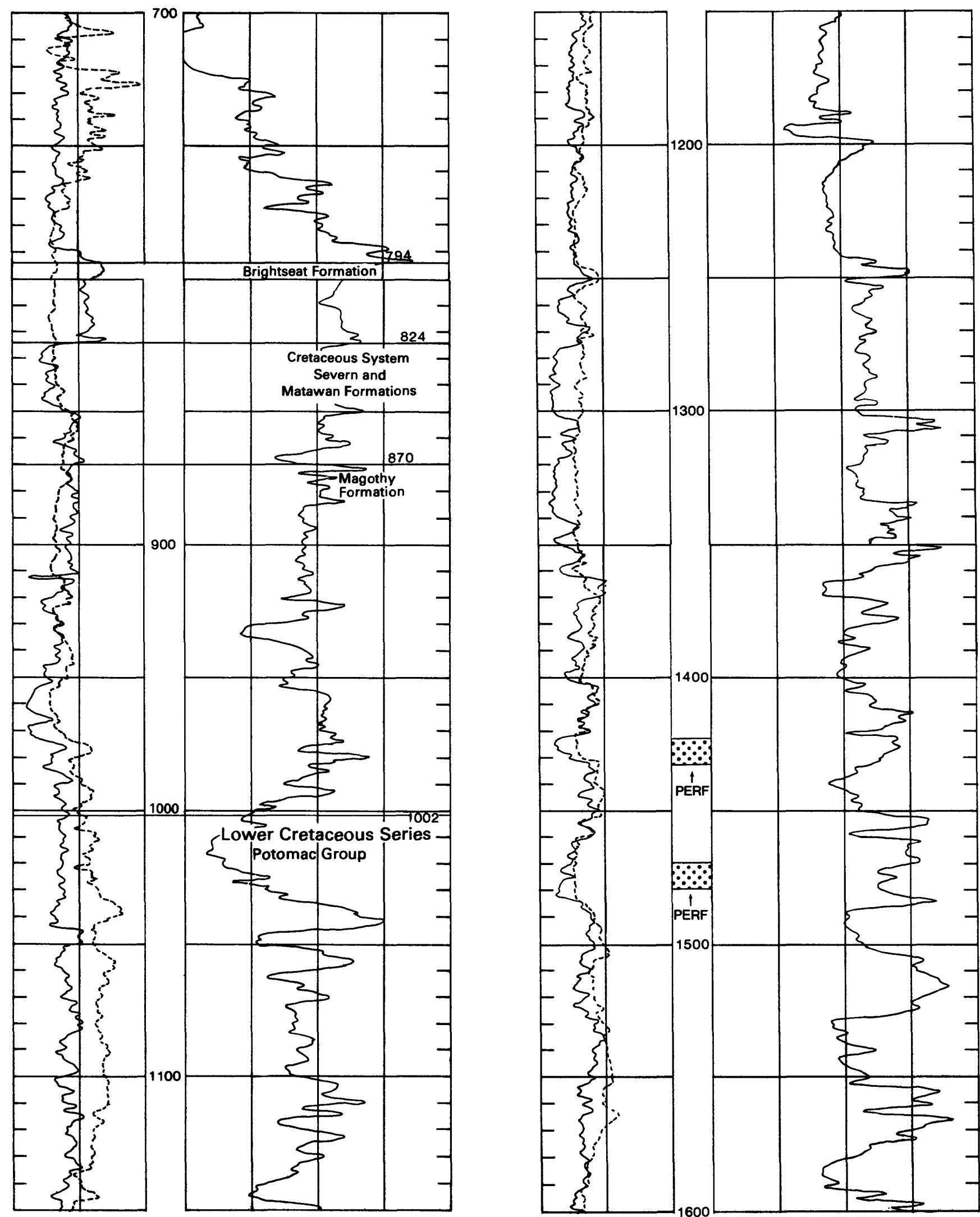

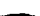

Figure 4. Borehole-compensated sonic log, with gamma-ray and caliper logs, screened and perforated zones, and formation tops-Continued. 

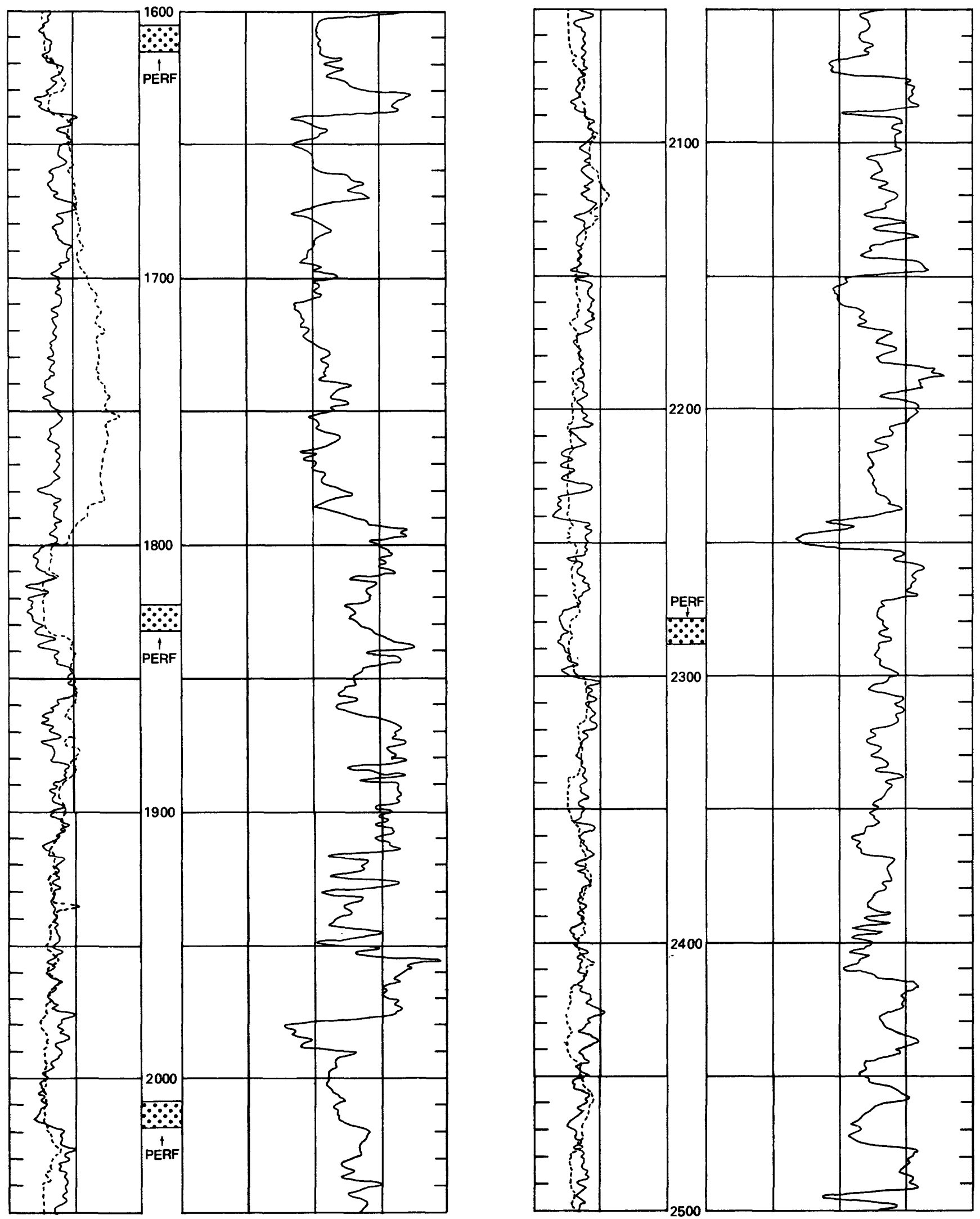

Figure 4. Borehole-compensated sonic log, with gamma-ray and caliper logs, screened and perforated zones, and formation tops-Continued. 

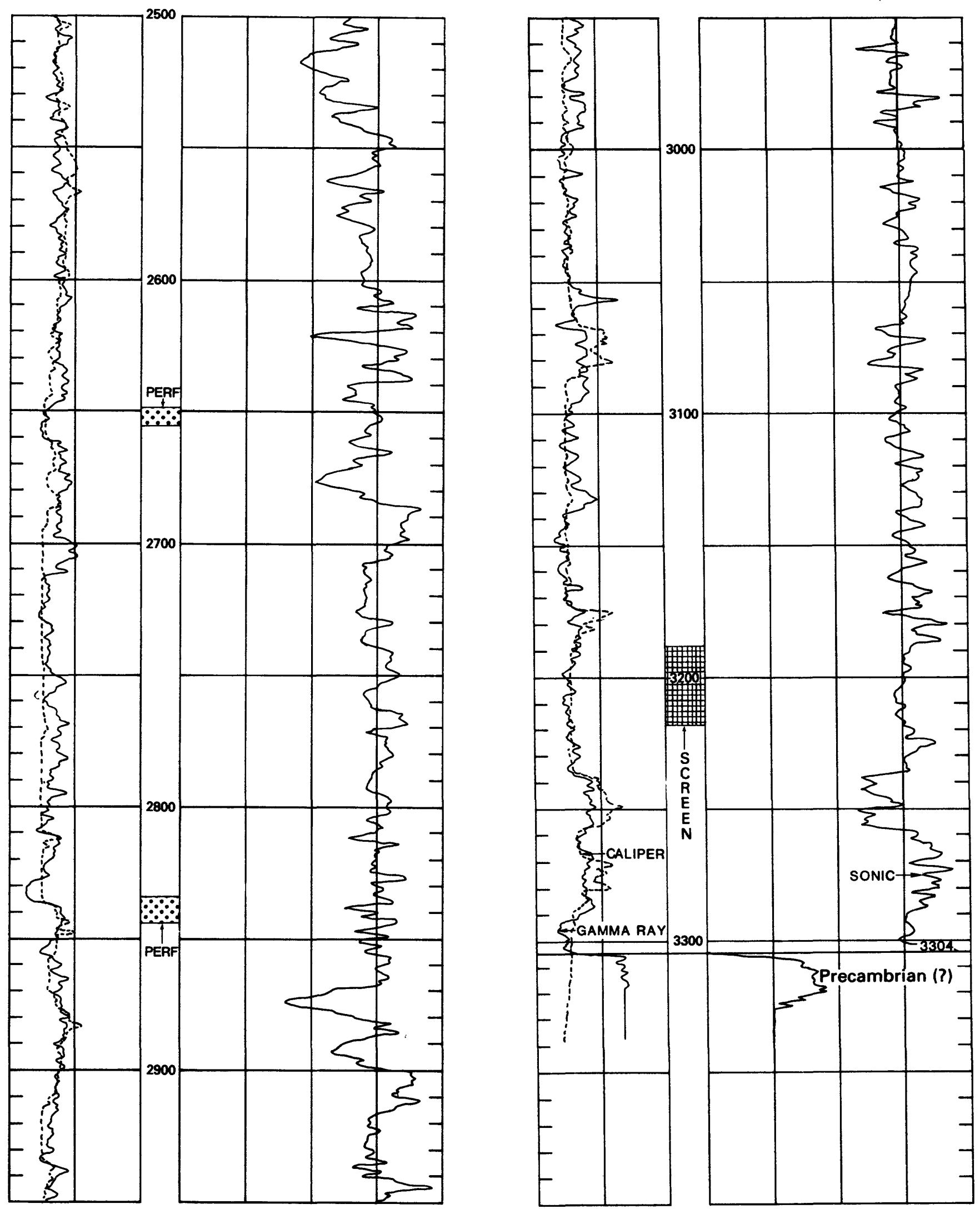

Figure 4. Borehole-compensated sonic log, with gamma-ray and caliper logs, screened and perforated zones, and formation tops-Continued. 
Table 2. Stratigraphy at test well DO-CE 88

\begin{tabular}{|c|c|c|c|c|}
\hline System & Series & Group or formation & Lithology & $\begin{array}{c}\text { Thickness } \\
\text { (ft) }\end{array}$ \\
\hline Quaternary(?) & Pleistocene(?) & & Sandy clay and brown quartz sand. & 48 \\
\hline \multirow{5}{*}{ Tertiary } & Miocene & $\begin{array}{l}\text { Chesapeake Group } \\
\text { (lower part) }\end{array}$ & $\begin{array}{l}\text { Pale brown, very fine to medium quartz sand with } \\
\text { shell fragments. } \\
\text { Silty clay and gray silt. }\end{array}$ & 297 \\
\hline & \multirow[b]{2}{*}{ Eocene } & Piney Point Formation & Brown, very fine to coarse, glauconitic quartz sand. & 192 \\
\hline & & Nanjemoy Formation & $\begin{array}{l}\text { Very fine to medium glauconitic quartz sand. } \\
\text { Gray, glauconitic silty clay. } \\
\text { Grayish-green glauconitic silt. }\end{array}$ & 128 \\
\hline & \multirow{2}{*}{ Paleocene } & Aquia Formation & $\begin{array}{l}\text { Greenish-black and brown glauconitic sand. } \\
\text { Gray, silty, glauconitic, calcareous clay. } \\
\text { Greenish-gray glauconitic silt. }\end{array}$ & 124 \\
\hline & & Brightseat Formation & $\begin{array}{l}\text { Greenish-gray silty clay and greenish-black, fine } \\
\text { glauconitic sand. }\end{array}$ & 30 \\
\hline \multirow{3}{*}{ Cretaceous } & \multirow[t]{2}{*}{ Upper Cretaceous } & $\begin{array}{l}\text { Severn and Matawan } \\
\text { Formations, } \\
\text { undifferentiated }\end{array}$ & Fine to very coarse glauconitic and clayey sand. & 46 \\
\hline & & Magothy Formation & Very fine to very coarse glauconitic quartz clayey sand. & 132 \\
\hline & Lower Cretaceous & $\begin{array}{l}\text { Potomac Group, } \\
\text { undifferentiated }\end{array}$ & $\begin{array}{l}\text { Alternating layers of very fine to very coarse } \\
\text { quartz sand, gray, brown, and green silt, and } \\
\text { gray and brown silty and sandy clay. }\end{array}$ & 2,302 \\
\hline \multicolumn{2}{|l|}{ Precambrian(?) } & Basement complex & Quartz monzonite gneiss. & \\
\hline
\end{tabular}

The upper part of the compensated (for hole diameter) neutron-formation density $\log$ (fig. 3) reads porosity directly from both the neutron and the density readings. However, both porosity logs are based on the assumption that the matrix is predominantly limestone rather than sand and clay, as is actually the case. The porosity values based on formation density are higher than if the conversion to porosity had been based on the assumption of a sand matrix, and those based on neutron logging are lower. These effects can be adjusted for using methods given by Schlumberger Limited (1972, p. 45-47; 1977, p. 16-17). Porosity values derived from the neutron log are close to true effective porosity, after adjustment, for clean sand formations, but are too high where clay is present.

Formation-water resistivities calculated from the Schlumberger spontaneous-potential log and the reported mud-filtrate resistivity of $2.85 \mathrm{ohm}$-meters at $20.6^{\circ} \mathrm{C}$ were unrealistically low. The mud sample measured by Schlumberger was probably not representative of the mud in the hole. The resistivity of the mud filtrate at the time of the Survey's electric $\log$ to $2,900 \mathrm{ft}$ was $9.05 \mathrm{ohm}$-meters at $20.6^{\circ} \mathrm{C}$ (calculated from specific conductance). Dilution of the drilling mud by salty formation water while the last $400 \mathrm{ft}$ were being drilled might have lowered its resistivity; however, more reasonable water resistivities were calculated from the Schlumberger log using 9.05 ohm-meters. Formation-water resistivities calculated from the Schlumberger deepinduction log, using formation factors estimated by various methods, were in closer agreement with measured resistivities than were those calculated from the spontaneous-potential log, but are not reported here because adequate water-quality data were obtained from analyzed samples.

The Virginia Polytechnic Institute and State University ran a temperature $\log$ in the cased well to $3,030 \mathrm{ft}$ below kelly-bushing datum on March 13, 1981 (fig. 5). The maximum temperature, at the base of the logged interval, was $41.9^{\circ} \mathrm{C}$, and the least-squares gradient between 1,002 and $3,030 \mathrm{ft}$ was $27.5^{\circ} \mathrm{C} / \mathrm{km}$, or $0.00838^{\circ} \mathrm{C} / \mathrm{ft}$ (Wilson S. McClung, Virginia Polytechnic 


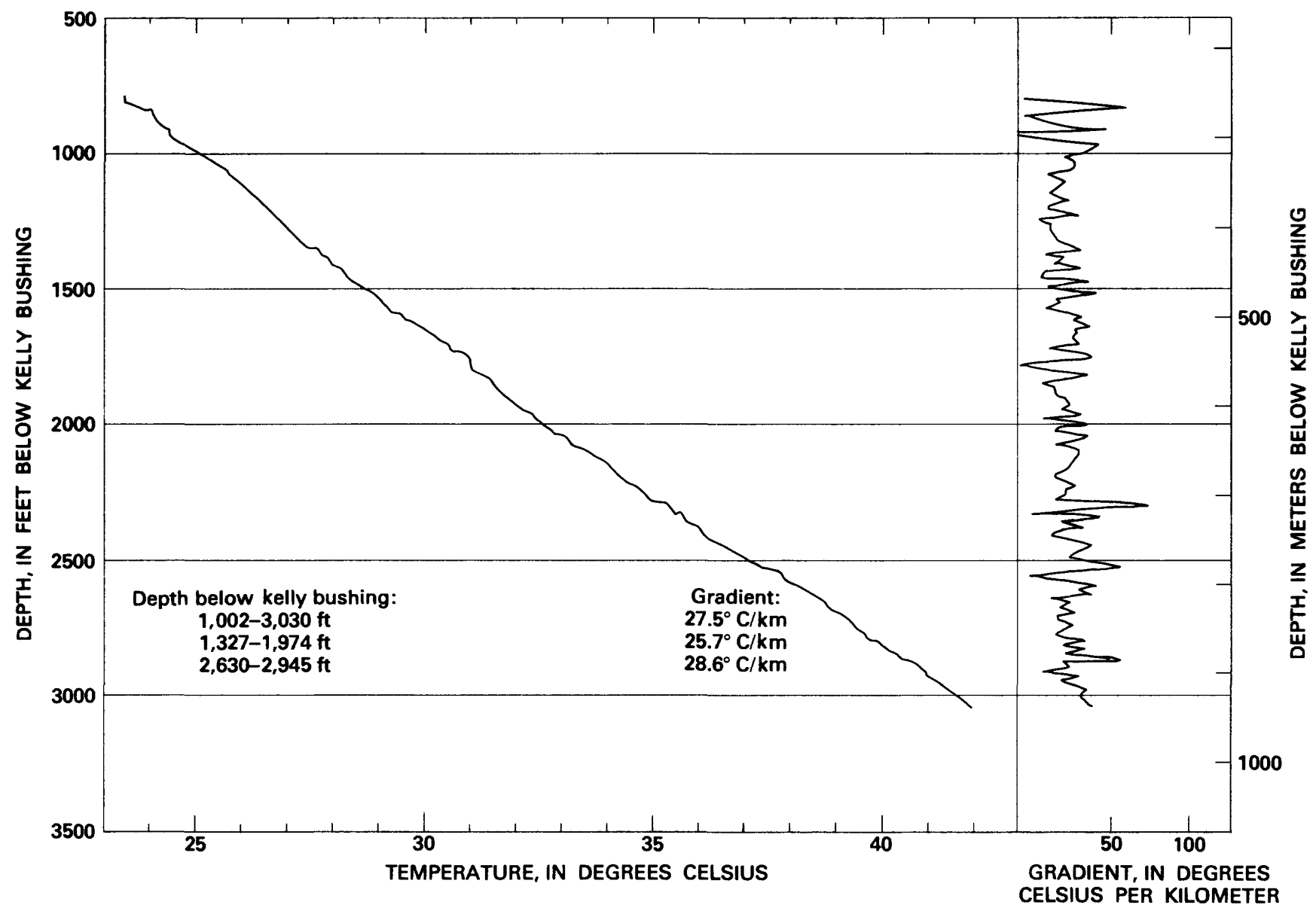

Figure 5. Temperature $\log$.

Institute and State University, written commun., November 11,1981$)$. It is presumed that the $\log$ was run long enough after grouting (about February 13) and after the first pumping test (March 1) for the temperature gradient to have stabilized.

\section{Cores}

\section{Coring Methods}

Cores were taken with a 10 -ft wireline core barrel. From $730 \mathrm{ft}$ to total depth, an inner lining of steel tubing having an inner diameter of $1.9 \mathrm{in}$. and a wall thickness of 0.06 in. (automotive-exhaust and electric-conductor pipe) was used in the core barrel to enclose the cores. This was done to protect them from deformation, abrasion, and invasion by drilling mud. Relatively few sand cores were taken; the coring equipment was not well adapted to recovering cores of clean unconsolidated sand. The tubing was sawed into convenient lengths for examination and removal of samples for squeezing, and into 6-in. lengths, sealed with paraffin at each end, for hydraulic analysis.

\section{Lithologic Descriptions of Cores}

The lithologies of the cores, determined by handlens and microscopic examination and by grain-size analysis, are given in table 3.

\section{Paleontology}

The ages of the cores, based on identification of microfossils, are given in table 3. Tables 4-12 list the species identified.

\section{Hydraulic Analysis}

Core Laboratories, Inc., Houston, Tex., hydraulically analyzed 14 core samples (table 3 ). Porosities and vertical hydraulic conductivities ranged from 22.4 percent (at 1,111 ft) to 41 percent (at 730-732 ft), and from $1.5 \times 10^{-6} \mathrm{ft} / \mathrm{d}($ at $1,650-1,652 \mathrm{ft}$ ) to $1.3 \mathrm{ft} / \mathrm{d}$ (at $3,212 \mathrm{ft}$ ), 
Table 3. Core data

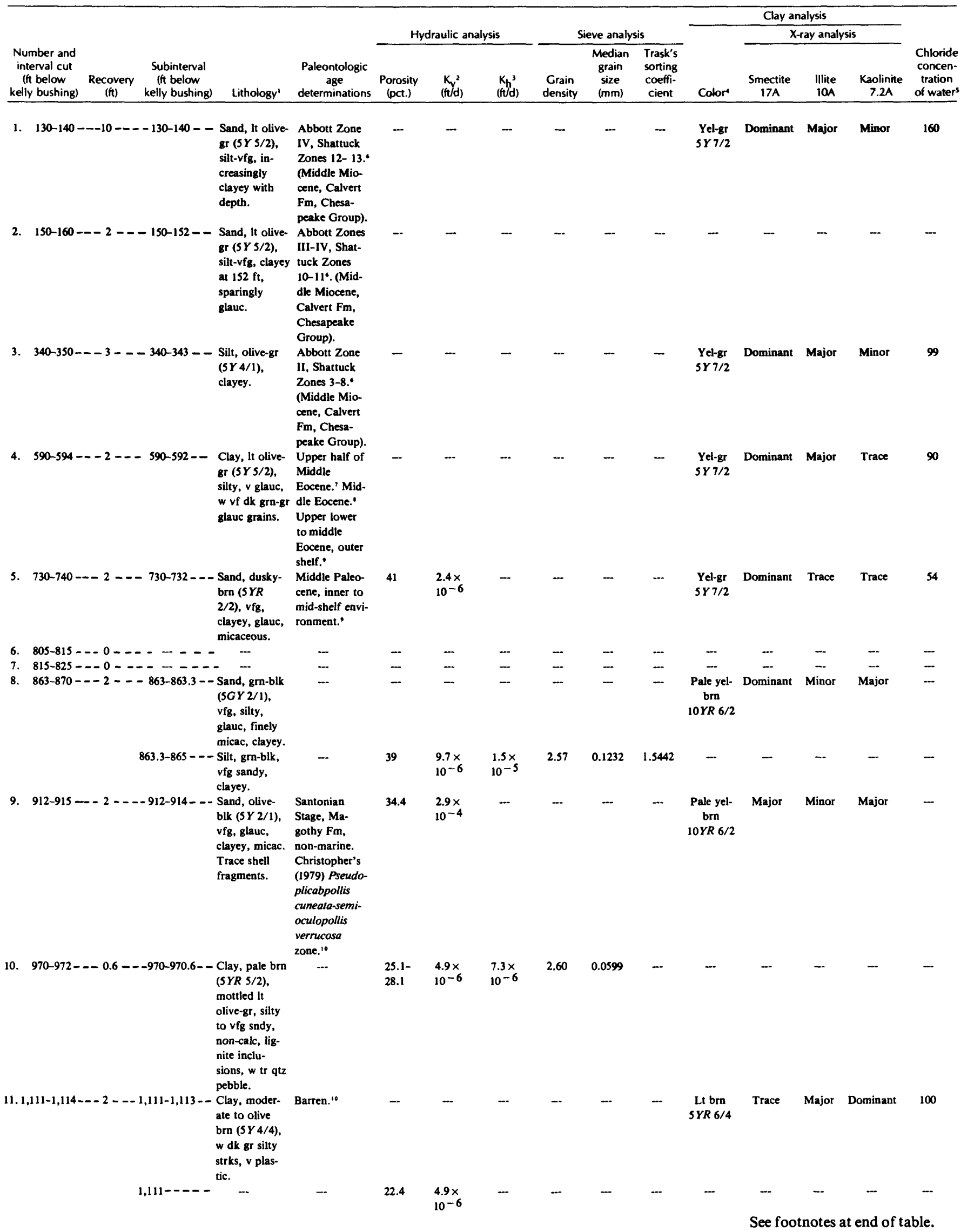


Table 3. Core data-Continued

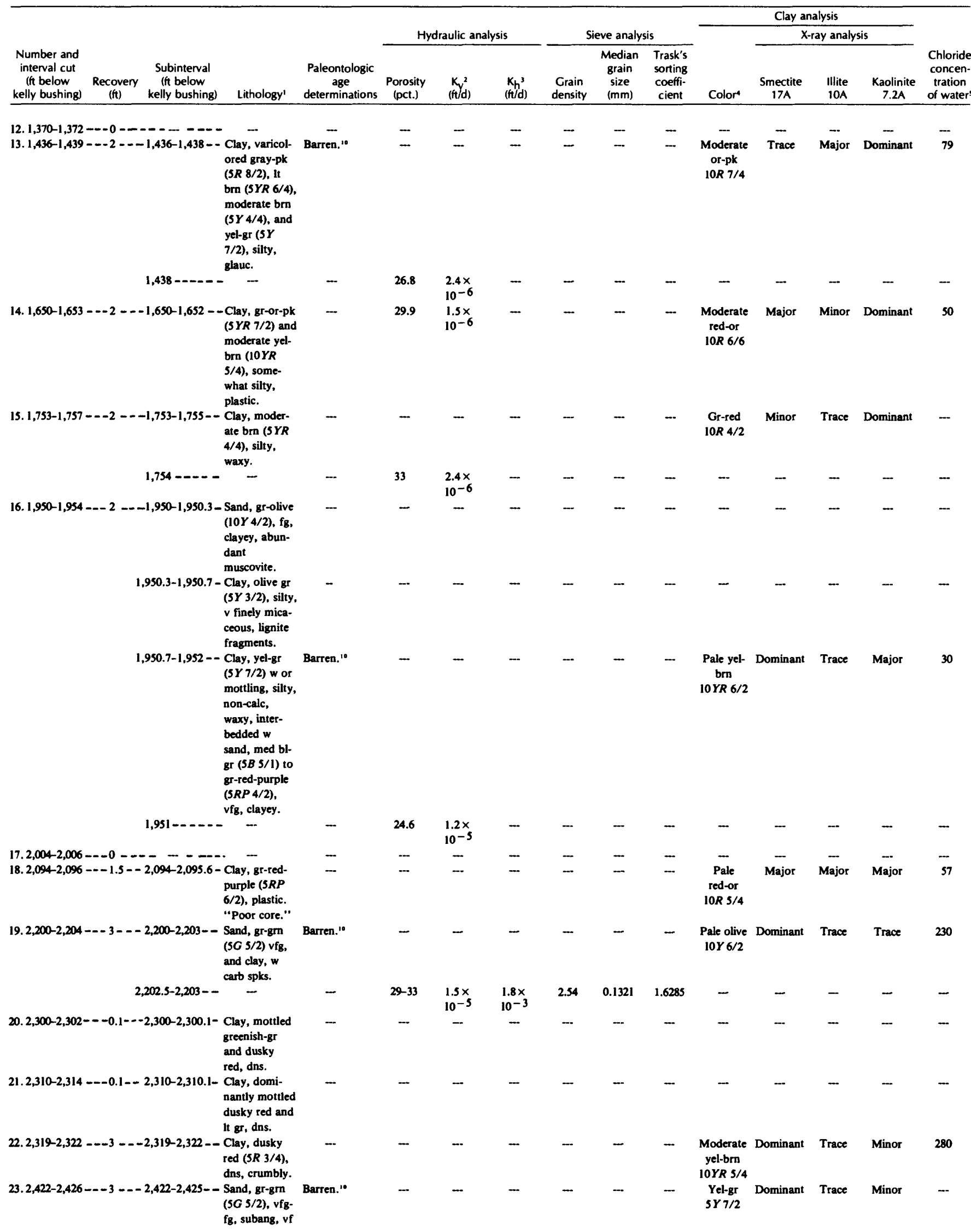


Table 3. Core data-Continued

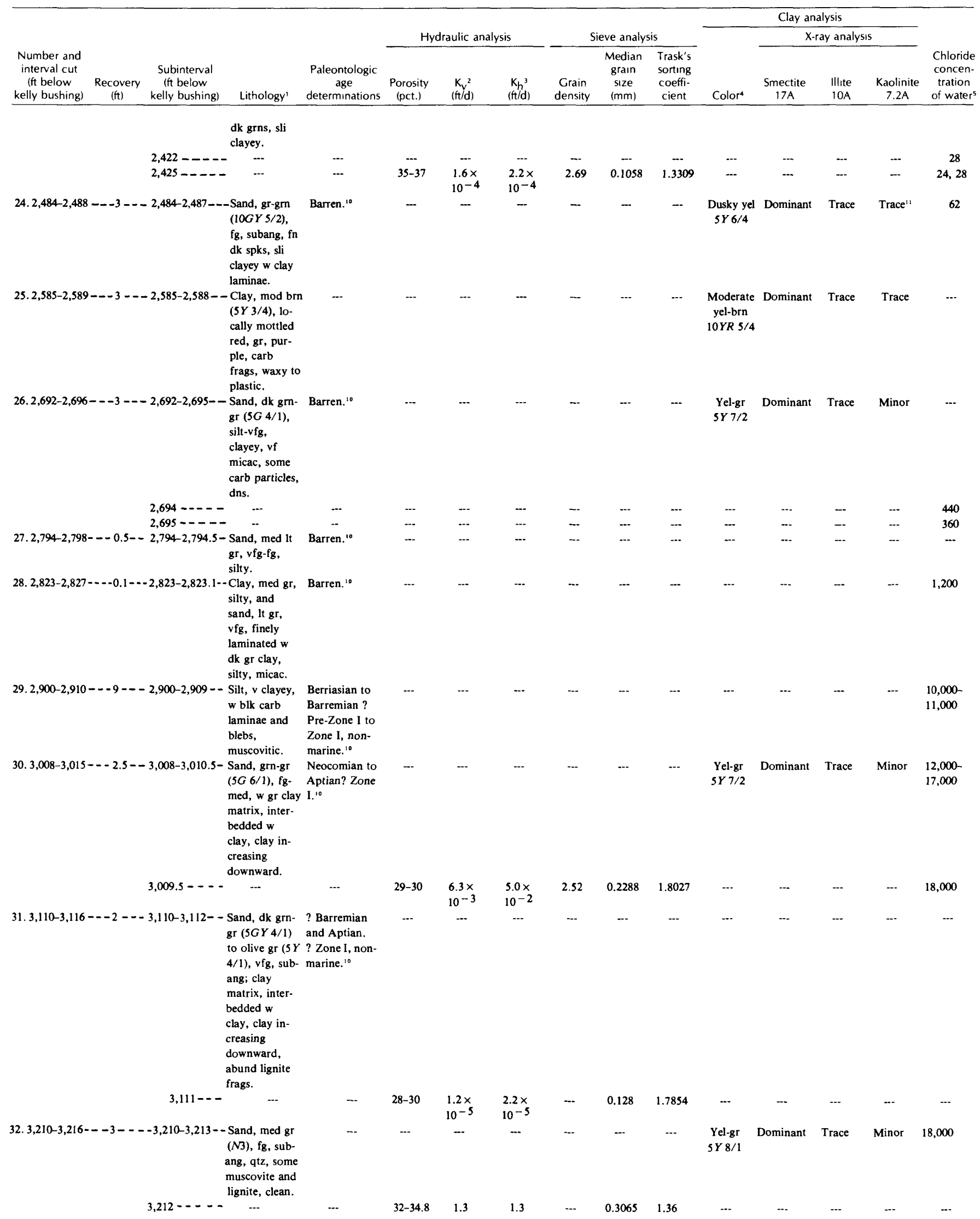

See footnotes at end of table. 
Table 3. Core data-Continued

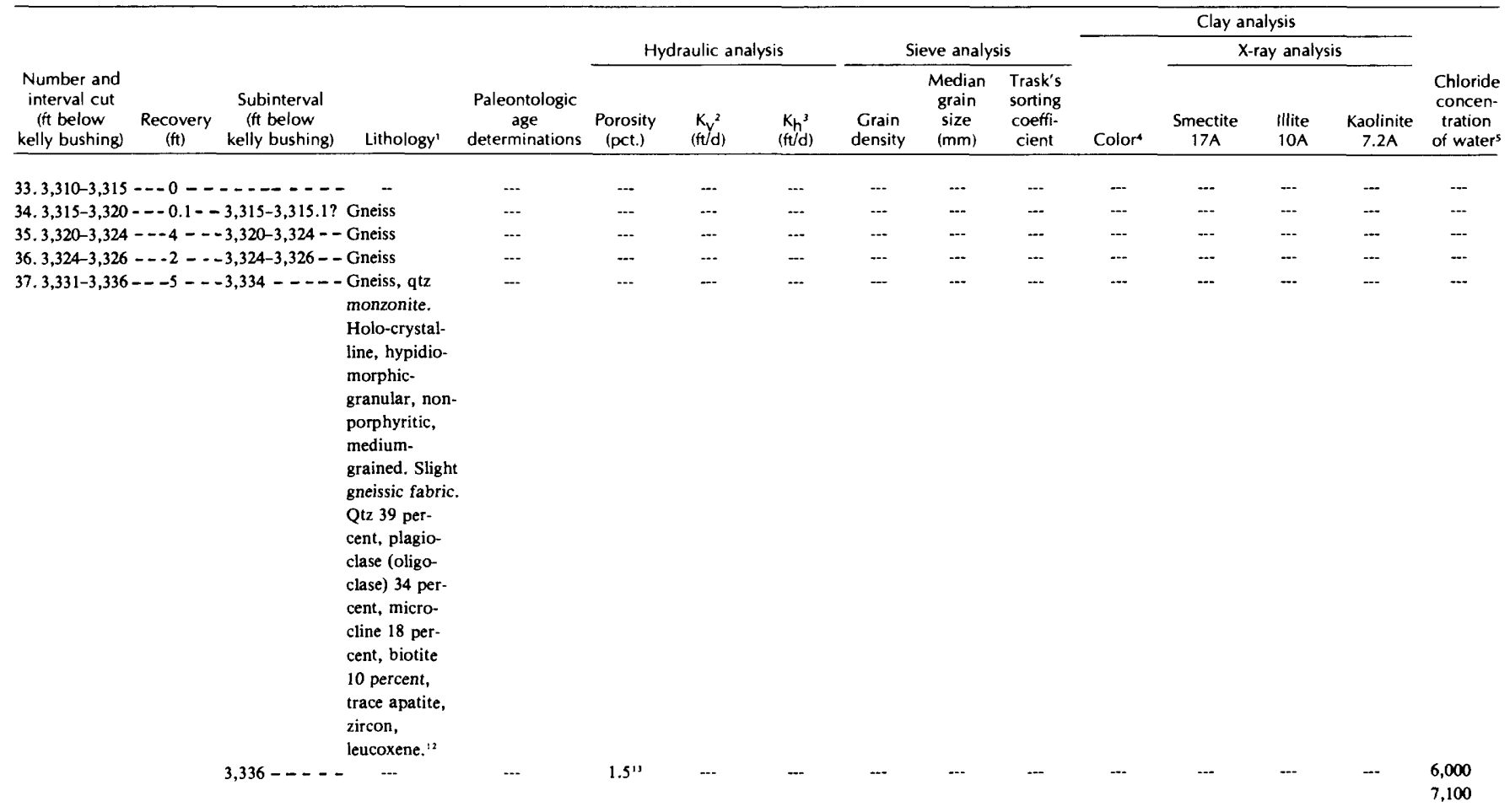

'Colors from wet core samples, code from Geological Society of America, 1948. Abbreviations: abund $=$ abundant,$b l=$ blue, blk $=$ black, brn $=$ brown, carb $=$ carbonaceous, $\mathrm{dk}=$ dark, $\mathrm{dns}=$ dense, $\mathrm{fg}=$ fine grained, frags $=$ fragments, glauc $=$ glauconitic, $\mathrm{gr}=$ gray, $\mathrm{grn}==$ green, $\mathrm{It}=$ light, med $=$ medium, micac $=$ micaceous, mod $=$ moderate, non-calc $=$ non-calcareous, or $=$ orange, $\mathrm{pk}=$ pink, qtz $=$ quartz, $\mathrm{sli}=$ slightly, sndy $=$ sandy, $\mathrm{spks}=$ specks, subang $=$ subangular, $\mathrm{tr}=$ trace, $v=$ very, $\mathrm{vf}=$ very fine, $\mathrm{vfg}=$ very fine grained, $w$ $=$ with, yel = yellow

'Vertical hydraulic conductivity, using simulated formation water at room temperature.

'Horizontal hydraulic conductivity, using simulated formation water at room temperature.

‘Colors from dry clay fractions, Geological Society of America, 1948. See footnote 1 for definition of abbreviations.

'In milligrams per liter. From partial analyses of water from core samples. Complete results are listed in table 14.

respectively. The horizontal hydraulic conductivities of seven sandy samples ranged from $7.3 \times 10^{-6} \mathrm{ft} / \mathrm{d}$ (at 970-970.6 ft) to $1.3 \mathrm{ft} / \mathrm{d}$ (at 3,212 ft). However, the most permeable sands penetrated by the well were not cored.

Porosity of the bedrock core ( 1.5 percent) was calculated from a water-content determination furnished by F. T. Manheim (U.S. Geological Survey, written commun., 1982).

\section{Sieve Analysis}

Core Laboratories ran sieve analyses on the seven sandy samples. The median grain size ranged from $0.0599 \mathrm{~mm}$ at a depth of 970-970.6 ft to $0.3065 \mathrm{~mm}$ at 3,212 ft. Trask's sorting coefficient (Krumbein and Pettijohn, 1938, p. 230-231), defined as the square root of the ratio of the grain diameter of the third quartile to the grain diameter of the first quartile (with the first quartile representing the finest material), ranged from
'Determination based on diatoms by William H. Abbott, Mobil Exploration and Producing Services, May 1981. Zones defined in Abbott (1978) and Shattuck (1904)

'Determination based on dinoflagellates by Lucy Edwards, U.S. Geological Survey, Sept. 22 1981 .

'Determination based on sparse, poorly preserved foraminifers by Richard Z. Poore, U.S Geological Survey, April 20, 1981.

'Determination based on foraminifers by Richard K. Olsson, Rutgers University, June 10, 1981

${ }^{10}$ Determination based on palynology by Gilbert J. Brenner, State University of New York at

New Paltz, June 1981. Zones defined in Brenner (1963) and Doyle and Robbins (1977).

' $\mathrm{X}$-ray analysis of clay also showed unidentified peak at $6.35 \mathrm{~A}$

${ }^{2}$ Description by Jonathan Edwards, Jr., Maryland Geological Survey, May 6, 1981.

${ }^{3}$ Porosity calculated from water content of .0059 .

1.3309 at a depth of $2,425 \mathrm{ft}$ to 1.8027 at $3,009.5 \mathrm{ft}$ (table 3). The grain-size distribution curves are shown in figure 6.

\section{X-Ray Analysis of Clay Fractions}

The qualitative mineralogical composition of the clay fractions of 20 core samples was determined by $\mathrm{X}$-ray diffractometer. The relative abundance of smectite (17A clays), illite (10A clays), and kaolinite (7.2A clays) was estimated from the heights of their respective peaks on the X-ray diffractograms. Four categories of abundance were designated: dominant, major, minor, and trace. The color of the air-dried clay fraction was determined using the Rock Color Chart (Geological Society of America, 1948).

The X-ray analyses (table 3) show that most of the clay samples belong to the montmorillonite group (smectites); however, a significant part of the section (starting with the transition sample at $912 \mathrm{ft}$ and extending through 
Table 4. Fossil species identified from core sample 130-140 feet

Diagnostic plant microfossils (G. J. Brenner, State University of New York at New Paltz, written commun., June 1981):

Series determination: Miocene (not above middle Miocene)

Paleoecology: Marine

$$
\text { Range }
$$

Long range

Paleocene to Holocene

Eocene to middle Miocene
1. Fagus sp.

2. Quercus (oak)

3. Periporopollenites cf. p. sp. z Bebout, 1980

4. Carya (hickory)

5. Unidentified acritarchs (marine)

\section{-- $\quad$ Rare.}

Frequency

Rare.

Abundant.

Sparse.

Sparse.

Species (3) has not been found above the middle Miocene in the B-2 Outer Continental Shelf well (Bebout, 1980). An OakHickory assemblage is typical of the marine Miocene of Maryland.

Dinoflagellates (Lucy E. Edwards, U.S. Geological Survey, written commun., Sept. 22, 1981):

$139.5 \mathrm{ft}$ :

Hystrichosphaeropsis obscura
Lejeunecysta sp.
Operculodinium centrocarpum

$135 \mathrm{ft}$ :

Lejeunecysta sp.

Palaeocystodinium golzowense

$130 \mathrm{ft}$ :

Cyclopsiella cf. C. elliptica

Hystrichokolpoma rigaudiae

Hystrichosphaeropsis obscura

Lejeunecysta sp.

Lingulodinium machaerophorum

Operculodinium centrocarpum
Palaeocystodinium golzowense Tuberculodinium vancampoae plus new genus, new species

Spiniferites pseudofurcatus

Tuberculodinium vancampoae

Palaeocystodinium cf. P. golzowense

Spiniferites pseudofurcatus

Spiniferites sp.

Tectatodinium pellitum

Tuberculodinium vancampoae

plus new genus, new species

Table 5. Fossil species identified from core sample 150-152 feet

Dinoflagellates (Lucy E. Edwards, U.S. Geological Survey, written commun., September 22, 1981):

Batiacasphaera sphaerica

Bitectatodinium tepikiense

Corrudinium sp.

Hystrichokolpoma rigaudiae

Hystrichosphaeropsis obscura

Lejeunecysta sp.

Melitasphaeridium asterium

Middle Miocene flora.
Operculodinium cf. $O$. israelianum

Palaeocystodinium golzowense

Pentadinium laticinctum

Spiniferites $\mathrm{sp}$.

Systematophora placacantha

Tuberculodinium vancampoae

plus two new genera, new species the sample at $1,753 \mathrm{ft}$ ) is dominated by the kaolinite group (kandites). This part of the section corresponds approximately to the Magothy Formation of Late Cretaceous age and the upper third of the Potomac Group of Early Cretaceous age.

\section{Heavy Mineral and Feldspar Identification}

Table 13 shows the occurrence of heavy minerals and feldspars as identified by James P. Owens, U.S.
Geological Survey, in selected core samples. Owens (written commun., April 23, 1982) noted that epidote and igneous apatite were abundant in the sediments of the Potomac Group in DO-CE 88, but less abundant than in the U.S. Geological Survey Oak Grove test hole (fig. 1), located about $30 \mathrm{mi}$ east-southeast of Fredericksburg , Va. (Reinhardt, Christopher, and Owens, 1980). The probable source of the apatite in the Oak Grove core is granite and gneiss exposed near Fredericksburg. The corresponding section in DO-CE 88 
Table 6. Fossil species identified from core sample 340-343 feet

Diagnostic plant microfossils (G. J. Brenner, State University of New York at New Paltz, written commun., June 1981):

Poor recovery of palynomorphs did not allow this sample to be accurately dated. The presence of only Quercus grains suggests a Cenozoic age. A few fragments of circular diatoms indicate a marine environment.

Dinoflagellates (Lucy E. Edwards, U.S. Geological Survey, written commun., September 22, 1981):

Cyclopsiella cf. C. elliptica

Palaeocystodinium golzowense

Heteraulacacysta sp.

Spiniferites sp.

Lejeunecysta sp.

Tuberculodinium vancampoae

Lingulodinium machaerophorum

Foraminifers (Richard K. Olsson, Rutgers University, written commun., June 10, 1981):

Number of specimens

Hanzawaia cf. concentrica

$1-10$

Buliminella cf. elongata

$1-10$

Uvigerina sp.

$1-10$

Contains a sparse fauna with much evidence of dissolution. Age determination not restricted-Oligocene to Holocene. Environment of deposition is mid-outer shelf, a diatom-radiolarian facies.

apparently received at least part of its sediment from a northerly or northwesterly source, according to Owens.

\section{Lithologic Log}

The interpretative lithologic log in table 14 was prepared from a combination of the driller's log, the geologist's field log, microscopic examination of cuttings samples, core descriptions, and geophysical logs. Lithologic boundaries were interpreted from the geophysical logs.

\section{Aquifer Tests}

Aquifer tests were conducted at five depths to determine the transmissivity and hydraulic conductivity of the screened or perforated zones (table 15).

The initial test was of the interval screened below the casing from 3,188 to $3,218 \mathrm{ft}$ below kelly-bushing datum. The well was pumped continuously at approximately $30 \mathrm{gal} / \mathrm{min}$ for 8 hours. Water levels in the pumping well were recorded during the drawdown and recovery phases of the test. Total drawdown during the drawdown phase was $71.09 \mathrm{ft}$. However, drawdown remained fairly constant following the first several minutes of the test. A plot of drawdown versus time is given in figure 7.

During the recovery phase of the test, water levels rose above the prepumping static water level of $61.9 \mathrm{ft}$ below kelly-bushing datum in the first $3 \mathrm{~min}$. For the remaining $27 \mathrm{~min}$ of measurement, water levels slowly declined toward the prepumping static level.
Ground-water temperature at the point of discharge from the well was monitored intermittently. Measured temperatures increased from $28^{\circ} \mathrm{C}$ at time $(t)$ $=30 \mathrm{~min}$ to $35^{\circ} \mathrm{C}$ at $t=150 \mathrm{~min}$. For the remainder of the drawdown phase of the test, the temperature at the wellhead remained constant at $35^{\circ} \mathrm{C}$.

Routine straight-line aquifer-test analysis techniques (Cooper and Jacob, 1946; Lohman, 1972, p. 19, 21) do not yield an acceptable solution when applied to the observed drawdown. During the test, the increase in temperature of the pumped water caused an accompanying decrease in water density. Hence, the observed drawdowns must be temperature-corrected to analyze the test data accurately.

Figure 8 shows temperature profiles in the well at various times during the drawdown phase of the test. The profile at $t=0 \mathrm{~min}$ is derived from the temperature $\log$ (fig. 5) and is approximated by two straight-line segments having similar slopes. The average prepumping temperature of water in the well is $29.93^{\circ} \mathrm{C}$. It was assumed that, during pumping, the temperature of the water entering the well $\left(43.11^{\circ} \mathrm{C}\right)$ was constant through time and that the temperature profile in the well was linear at all times. Temperature profiles were constructed from measured wellhead temperatures, and an average temperature of the water in the well was computed for each profile (fig. 8).

Head is a function of water density, and density varies with temperature. Thus, density and, in turn, head must be corrected for varying temperatures. In general, the corrections required are negligible for shallow wells and are ignored; however, for deep wells, the corrections may become significant. If aquifer response is expressed in terms of pressure rather than head, as the 
petroleum industry uses pressure data from drill-stem tests (Bredehoeft, 1965), corrections for temperature effects on the water-column can be avoided when determining hydraulic parameters.

Pressure at the well screen is independent of the density of the fluid in a well; therefore, pressures for cold and hot water can be equated:

$$
\boldsymbol{P}_{c w}=\boldsymbol{P}_{h w} \text {, }
$$

where pressure $(P)$ is defined in terms of hydraulic head $(h)$ as $P=\varrho g(h+z) ; c w$ refers to cold water, $h w$ is hot water, $z$ is the elevation head, $e$ is the density of the water in the well, and $g$ is the gravitational acceleration constant. Equating pressures and solving for cold-water head yields:

$$
h_{c w}=\frac{\varrho_{h w}}{\varrho_{c w}}\left(h_{h w}+z\right)-z .
$$

As the relation of water density to temperature is known, water levels can be adjusted for the increasing temperature.

The density of the water in DO-CE 88 for the 3,188- to 3,218 -ft zone is $1.032 \mathrm{gm} / \mathrm{mL}$ (grams per milliliter) at $20^{\circ} \mathrm{C}$, which is approximately equivalent to a 4 percent (by weight) brine. The following linear approximation of density versus temperature in degrees Celsius $(T)$ can be used:

$$
\varrho=1.032+a(T-20) .
$$

The values of $a$ used in equation 3 are interpolated from published values for a 4 percent (by weight) brine at various temperatures (INTERCOMP Resource Development and Engineering, Inc., 1976, p. 4.2-4.3). The calculated average densities of the brine in the well at various times during the drawdown phase of the pumping test are:

$\begin{array}{rr}\text { time (min) } & g m / m L \\ & \\ 0 & 1.0296 \\ 30 & 1.0281 \\ 60 & 1.0277 \\ 110 & 1.0274 \\ >150 & 1.0270\end{array}$

\section{Interpretation of Temperature-Corrected Drawdown}

Both uncorrected and density-corrected drawdowns for the pumping test are shown in figure 7. The uncorrected drawdowns rapidly increased during the first $\mathbf{1 0}$ min of the test, as expected. For the remainder of the test, water levels remained approximately constant. The density-corrected drawdowns show a linear trend that is readily analyzed. The computed transmissivity of the screened zone containing brine at $29.9^{\circ} \mathrm{C}$ is $380 \mathrm{ft}^{2} / \mathrm{d}$, and its average hydraulic conductivity is 12.5 $\mathrm{ft} / \mathrm{d}$. This is a typical value for fine sand (Lohman, 1972, table 17) and, hence, is in agreement with the lithologic description of drill cuttings for this interval.

After pumping ceased, water levels rose rapidly above the prepumping static level because the well contained hotter, less dense water than before pumping began. Then, as the water in the well cooled, water levels slowly declined to the prepumping static level. During pumping, cold water in the well was replaced by hotter water from the aquifer. In contrast, during recovery, hot water in the well cooled and water levels declined. Because of the complex nature of these processes, transmissivity was not computed from recovery data.

The remaining tests were also corrected for temperature effects when necessary. Temperature measurements were insufficient to define the drawdown curve rigorously, and specific-capacity data were used to estimate transmissivity and hydraulic conductivity (Brown, 1963 , p. 336). A storage coefficient and a well radius of $1 \times 10^{-4}$ and $0.5 \mathrm{ft}$, respectively, were assumed. The specific capacities used in the analysis were computed from temperature-corrected drawdown near the end of the drawdown phase of each test.

Hydraulic properties (transmissivity and hydraulic conductivity) are dependent on both the chemical composition and temperature of the water contained in the aquifer. The results of the aquifer-test analysis may not represent in situ temperature conditions. Therefore, intrinsic permeability, which is independent of fluid properties, has been computed for each of the tests. The results are summarized in table 15 . 
Table 7. Fossil species identified from core sample 590-592 feet

Dinoflagellates (Lucy E. Edwards, U.S. Geological Survey, written commun., September 22, 1981):
Achilleodinium biformoides
Microdinium n. sp.
Adnatosphaeridium sp.
Pentadinium membranaceum
Apteodinium australiense
Rhombodinium glabrum
Cordosphaeridium gracile
Samlandia chlamydophora
Corrudinium n. sp.
Samlandia reticulifera
Deflandrea phosphoritica
Spiniferites pseudofurcatus
Diphyes colligerum
Spiniferites ramosus var. granomembranaceus
Heteraulacacysta leptalea
Tectatodinium pellitum
Hystrichostrogylon membraniphorum
Wetzeliella articulata

Lentinia sp.

Melitasphaeridium pseudorecurvatum

Age is upper half of middle Eocene.

Foraminifers (Richard K. Olsson, Rutgers University, written commun., June 10, 1981):

Gaudryina cf. pseudocollinsi

$1-10$

$1-10$

Textularia sp.

Brazilina atlantisae

Turritilina sp.

Bulimina cf. subrotundata

Bulimina trigonalis

Anomalinoides alazanensis-

Pullenia compressiuscula

Cibicides west $i$

Alabamina midwayensis

Cibicidoides pippeni -

Gyroidinoides peramplus

Bulimina pupoides

Lenticulina sp.

Lagena striata

Lagena fenestrissima

Subbotina eocaena

Acarinina pentacamerata

Morozorella spinulosa-

Stilostomella sp.

Globulina gibba

Morozorella spinuloinflata

Pseudohastigerina wilcoxensis

Truncorotaloides cf. ruhri

$+1,000$

$+1,000$

$+1,000$

$11-100$

$11-100$

$1-10$

$11-100$

$11-100$

$11-100$

$100-1,000$

$11-100$

$1-10$

$1-\quad 10$

$11-100$

$100-1,000$

$+1,000$

$1-\quad 10$

$1-10$

$1-\quad 10$

$11-100$

$11-100$

$1-\quad 10$

Very rich in foraminifers. Outer shelf environment of deposition.

“Planktic foraminifers"' (Richard Z. Poore, U.S. Geological Survey, written commun., April 20, 1981):

Truncorotaloides collactea (Finlay)

T. bullbrooki (Bolli)

Pseudohastigerina micra (Cole)

Age: "Middle Eocene. Planktic foraminifers are sparse and poorly preserved." 


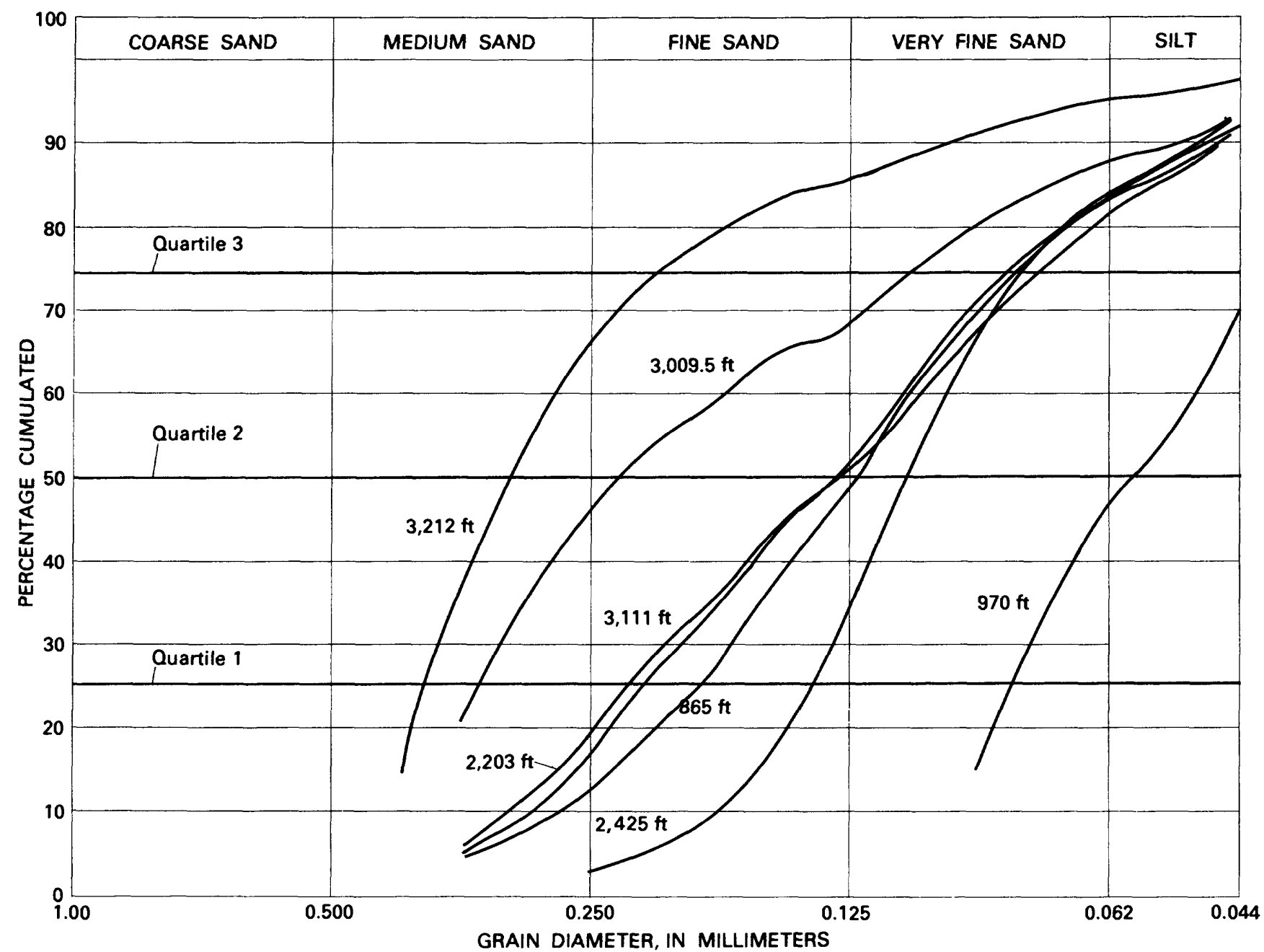

Figure 6. Grain-size distribution of core samples.

Table 8. Fossil species identified from core sample 730-732 feet

Foraminifers (Richard K. Olsson, Rutgers University, written commun., June 10, 1981):

Stilostomella paleocenica

$$
\begin{aligned}
& \text { Number of specimens } \\
& \text { 1- } 10 \\
& 11-100 \\
& 100-1,000 \\
& 1-\quad 10 \\
& 1-\quad 10 \\
& \text { 1- } 10 \\
& 1-\quad 10 \\
& 100-1,000 \\
& \text { 1- } 10 \\
& \text { 1- } 10 \\
& 1-\quad 10 \\
& 1-\quad 10 \\
& 1-10 \\
& 1-\quad 10
\end{aligned}
$$$$
\text { Epistominella minata }
$$$$
\text { Bulimina cacumenata }
$$

Evidence of a fair amount of solution of foraminiferal tests. Inner to mid-shelf environment of deposition. 


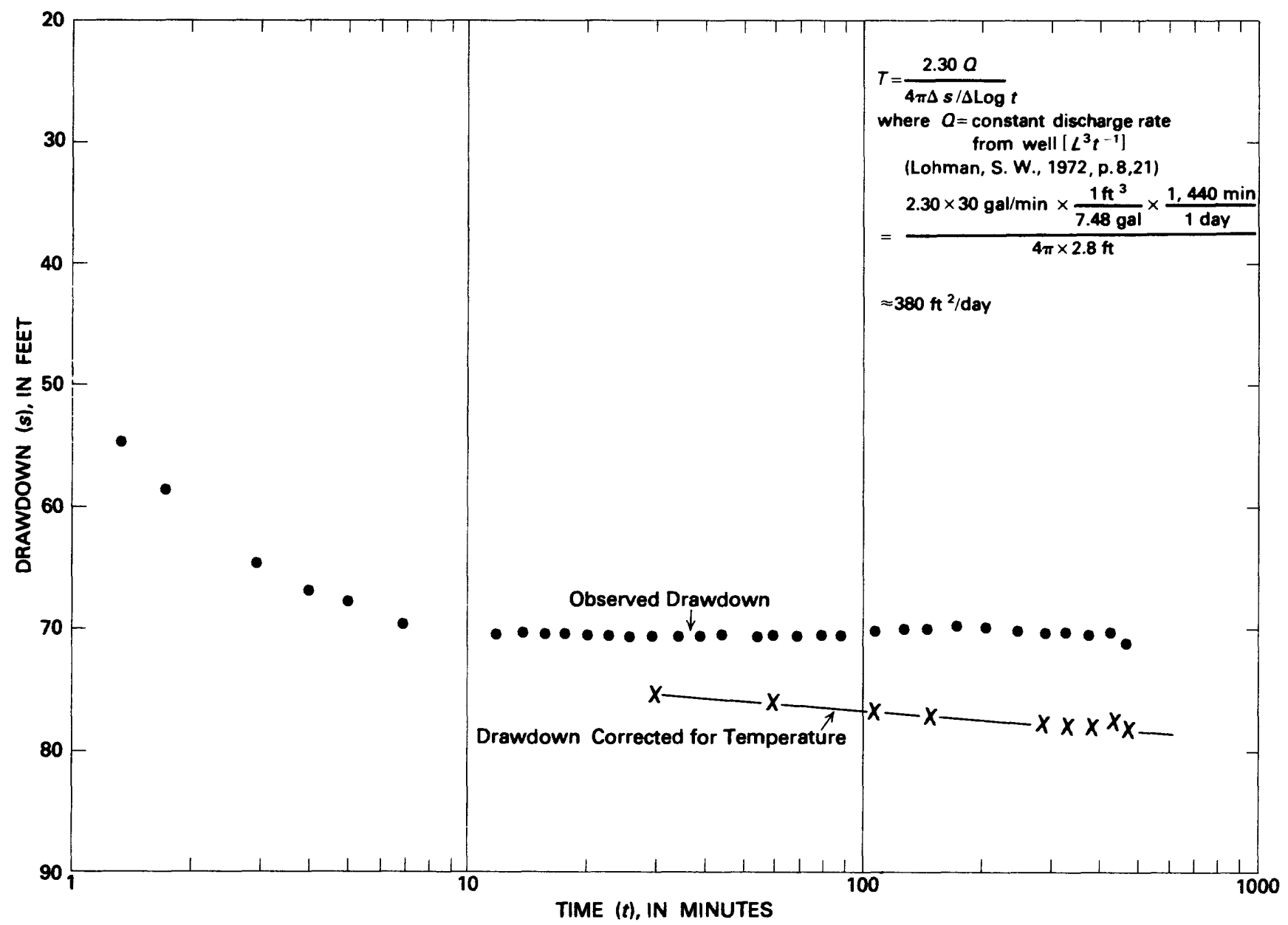

Figure 7. Computation of transmissivity $(T)$ of screened zone 3,188 to $3,218 \mathrm{ft}$ below kelly-bushing datum.

Table 9. Fossil species identified from core samples 912-915 feet

Diagnostic plant microfossils (G. J. Brenner, State University of New York at New Paltz, written commun., June 1981):

\section{Appendicisporites tricuspidatus}

2. Genus $B$ sp. $C$, Christopher, 1979

3. Plicapollis sp. G, Christopher, 1979

4. Santalacites minor

5. Semioculopollus verrucosa-

6. Stereisporites congruens

7. Tricolporites sp. q. Wolfe and Pakiser, 1971

8. Trudopollis sp. $B$

9. Vacuopollis sp.
Amboy Stoneware Clay Member of Magothy Formation

Cliffwood beds of Magothy Formation

Amboy Stoneware Clay Member to Cliffwood beds of Magothy Formation

Amboy Stoneware Clay Member to Cliffwood beds of Magothy Formation

Morgan and Cliffwood beds of Magothy Formation Cenomanian to Maestrichian

Cliffwood beds of Magothy Formation

Amboy Stoneware Clay Member to Cliffwood beds of Magothy Formation

Magothy Formation
Rare.

Rare.

Sparse.

Rare.

Rare.

Rare.

Sparse.

Common.

Common.

Based on the zonation of Christopher (1979), the sample at 913 feet car irith confidence be placed in the Pseudoplicabpollis cuneata-Semioculopollis verrucosa zone of Santonian Age. Stratigraphic correlation: Magothy Formation. Paleoecology: Nonmarine. 


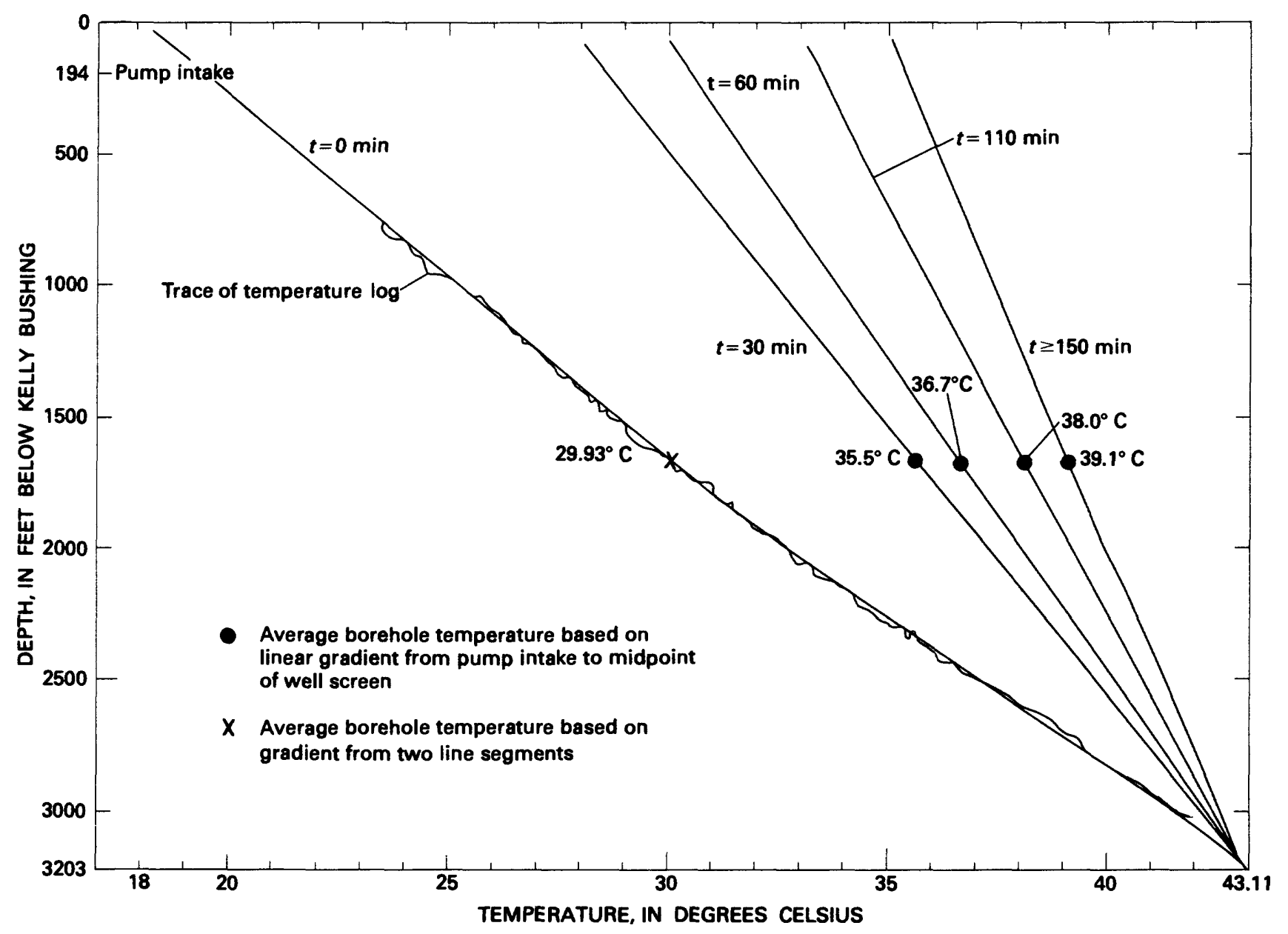

Figure 8. Temperature profiles during pumping test of screened zone 3,188 to $3,218 \mathrm{ft}$ below kelly-bushing datum.

Table 10. Fossil species identified from core sample 2,900-2,909 feet

Diagnostic plant microfossils (G. J. Brenner, State University of New York at New Paltz, written commun., June 1981):

Stage determination: Berriasian to Barremian?

Stratigraphic correlation: Pre-Zone I ? to Zone I

Paleoecology: Nonmarine

1. Alisporites

2. Concavissimisporites verrucatus

3. Klukisporites pseudoreticulatus-

4. Leptolepidites verrucatus

5. Lycopodiumsporites sp.

6. Lycopodiacidites ambifoveolatus

7. Parvisaccites radiatus

8. Podocarpidites sp.
Range

Frequency

Long range

Valanginian $\rightarrow$

Berriasian to Turonian

Berriasian to Albian

Long range

Zones I and II

Upper Jurassic and Berriasian to Albian

Long range
Sparse.

Rare.

Rare.

Rare.

Rare.

Rare.

Rare.

Rare.

Palynomorphs not distinctive of any zone. No typical angiosperms of Zone I are present. 
Table 11. Fossil species identified from core sample 3,008-3,010.5 feet

Diagnostic plant microfossils (G. J. Brenner, State University of New York at New Paltz, written commun., June 1981):

Stage determination: Neocomian to Aptian

Stratigraphic correlation: ? Zone I

The poor recovery did not allow a confident age determination. The best palynomorph with the narrowest range is a form described by Hughes and Croxton (1973) from the Dorset Wealden, listed as Biorecord 25 CICATR B2l Berriasian to Aptian (a form of Cicatricosisporites). A few other palynomorphs with long Cretaceous ranges were found. These are

1. Cicatricosisporites sp.

2. Appendicisporites sp.

3. Taurocusporites reduncus

Table 12. Fossil species identified from core sample 3,110-3,112 feet

Diagnostic plant microfossils (G. J. Brenner, State University of New York at New Paltz, written commun., June 1981):

Stage determination: Barremian ? to Aptian

Stratigraphic correlation: ? Zone I

Paleoecology: Nonmarine

Range

Frequency

1. Klukisporites pseudoreticulatus

Berriasian to Turonian

Rare.

2. Perotriletes striatus Barremian to Albian

Rare.

3. Pilosisporites sp.

4. Trilobosporites apiverrucatus

Berriasian to Albian Rare.

"Sample is too sparse to confidently date. However, Perotriletes striatus has not yet been reported from below the Barremian. In the Potomac Group, I found it much more common in the Barremian [to] Aptian, Zone I levels. I have often found it associated with megaspore Arcellites disciformis entrapped in the paddle-like appendages. If $P$. striatus is the microspore of this heterosporous form, then the presence of this microspore would increase the probability of the sample belonging to Zone I; since Arcellites disciformis first appears in the Barremian."

Table 13. Heavy minerals and feldspars in selected core samples'

\begin{tabular}{|c|c|c|c|c|c|c|c|c|c|c|c|c|c|c|c|c|c|c|c|c|}
\hline \multirow[b]{2}{*}{$\begin{array}{l}\text { Depth (ft } \\
\text { below kelly } \\
\text { bushing) }\end{array}$} & \multicolumn{5}{|c|}{ Percentage of light fraction } & \multicolumn{3}{|c|}{$\begin{array}{l}\text { Percentage of opaque } \\
\text { heavy-mineral fraction }\end{array}$} & \multicolumn{12}{|c|}{ Percentage of non-opaque heavy-mineral fraction } \\
\hline & $\begin{array}{l}\text { Rock } \\
\text { frag- } \\
\text { ments }\end{array}$ & $\begin{array}{l}\text { Com- } \\
\text { mon } \\
\text { quartz }\end{array}$ & $\begin{array}{l}\text { Polycry- } \\
\text { stalline } \\
\text { quartz }\end{array}$ & $\begin{array}{l}\text { Potas- } \\
\text { sium } \\
\text { feldspar }\end{array}$ & $\begin{array}{l}\text { Plagio- } \\
\text { clase } \\
\text { feldspar }\end{array}$ & $\begin{array}{l}\text { IIme- } \\
\text { nite }\end{array}$ & $\begin{array}{l}\text { Brown } \\
\text { ilme- } \\
\text { nite }\end{array}$ & $\begin{array}{l}\text { Leuco- } \\
\text { xene }\end{array}$ & $\begin{array}{l}\text { Horn- } \\
\text { blende }\end{array}$ & Epidote & Garnet & $\begin{array}{l}\text { Chlori- } \\
\text { toid }\end{array}$ & $\begin{array}{l}\text { Glau- } \\
\text { conite }\end{array}$ & $\begin{array}{l}\text { Staur- } \\
\text { olite }\end{array}$ & Kyanite & $\begin{array}{c}\text { Silli- } \\
\text { manite }\end{array}$ & $\begin{array}{l}\text { Tour- } \\
\text { maline }\end{array}$ & Rutile & Zircon & Apatite \\
\hline 130.5 & 14 & 81 & 3 & 3 & $\mathbf{t r}^{2}$ & - & - & - & 0 & 8 & 6 & 4 & 1 & 0 & 3 & 15 & 12 & 3 & 47 & $\mathbf{0}$ \\
\hline 135 & 10 & 86 & 1 & 4 & $\mathbf{t r}^{2}$ & - & - & - & 0 & 23 & 5 & 9 & 0 & 0 & 3 & 5 & 5 & 18 & 32 & 0 \\
\hline 139.5 & 2 & 92 & 0 & 6 & $t r^{2}$ & - & - & - & 0 & 32 & 12 & 8 & 0 & 0 & 0 & 24 & 4 & 12 & 8 & 0 \\
\hline 150 & 5 & 92 & 0 & 3 & $\operatorname{tr}^{2}$ & - & - & - & 0 & 2 & 10 & 4 & 0 & 0 & 0 & 17 & 21 & 2 & 42 & 0 \\
\hline $340^{3}$ & 12 & 75 & 0 & 12 & 0 & - & - & - & - & - & - & - & - & - & - & - & - & - & - & - \\
\hline $592^{4}$ & 0 & 70 & 0 & 30 & 0 & - & - & - & $\mathbf{P}^{s}$ & 0 & $\mathbf{P}^{s}$ & $\mathbf{P}^{s}$ & 0 & 0 & $\mathbf{P}^{s}$ & 0 & $\mathbf{P}^{s}$ & $\mathbf{P}^{3}$ & 0 & 0 \\
\hline 913 & 3 & 80 & 0 & 13 & 0 & 87 & 3 & 10 & 0 & 26 & 10 & 15 & 0 & 8 & 2 & 0 & 3 & 11 & 25 & 0 \\
\hline 1,951 & 35 & 63 & 0 & 2 & 0 & 49 & $\begin{array}{l}\text { very } \\
\text { abun- } \\
\text { dant }\end{array}$ & 51 & 5 & 13 & 1 & 0 & 0 & 11 & 4 & 0 & 13 & 18 & 35 & 0 \\
\hline 2,203 & 5 & 80 & 0 & 12 & 3 & 87 & 1 & 12 & 0 & 51 & 4 & 0 & 0 & 0 & 0 & 0 & 1 & 0 & 33 & 11 \\
\hline 2,484 & 0 & 45 & 0 & 32 & 23 & 63 & 15 & 12 & 0 & 14 & 9 & 0 & 0 & 3 & 1 & 0 & 5 & 0 & 68 & 0 \\
\hline 2,903 & 20 & 73 & 0 & 7 & 0 & 66 & 25 & 9 & $\operatorname{tr}^{2}$ & 38 & 5 & 4 & 0 & 8 & 3 & 0 & 2 & 3 & 36 & 1 \\
\hline 3,112 & 5 & 61 & 0 & 30 & 4 & 90 & 4 & 6 & 0 & 7 & 3 & 1 & 0 & 0 & 0 & 0 & 1 & 1 & 80 & 7 \\
\hline 3,212 & 8 & 40 & 2 & 44 & 6 & 30 & 15 & 55 & 0 & 72 & 7 & 0 & 0 & 5 & 1 & 0 & 1 & 0 & 5 & 9 \\
\hline
\end{tabular}

The fine and very fine sand fractions $>40$ microns ( 325 mesh) only, not the total sample. Trace, $<0.5$ percent.

'Mostly carbonate.

'Small sample, less accurate than other counts; heavy minerals consist of abundant diatoms

'Present. Heavy minerals consist mostly of opaque, green-black glauconite aggregates. replaced by pyrite, minor weathered glauconite. 
Table 14. Interpretative lithologic description, Well DO-CE 88 (USGS No. 3834010760320.01)

Owner: Eastern Shore Hospital Center

Location: Eastern Shore Hospital Center, Cambridge, Maryland

County: Dorchester

Prepared by: Henry Trapp, Jr., from microscopic examination of drill cuttings and cores adjusted to lithologic boundaries indicated by geophysical logs.

Datum: Kelly bushing of drill rig, $9.42 \mathrm{ft}$ above $\mathrm{msl}=5.0 \mathrm{ft}$ above land surface

\begin{tabular}{ccc}
\hline Lithology & $\begin{array}{c}\text { Thickness } \\
\text { (ft) }\end{array}$ & $\begin{array}{c}\text { Depth } \\
\text { (ft) }\end{array}$ \\
\hline
\end{tabular}

\section{Quaternary (?) System}

Pleistocene (?) Series

Clay, brown, sandy

Sand, brown, medium

Clay, blue, sandy

Sand, brown

Clay, blue, sandy

5

11

2

13

17

Tertiary (?) System

Miocene (?) Series

Chesapeake (?) Group (lower part)

Sand and shells, interbedded ${ }^{1}$

Sandstone, light brown (5YR 6/4), ${ }^{2}$ very fine to medium, predominantly fine, mostly angular to subangular, except for coarser grains, which are subrounded quartz. $\mathrm{Cal}$ careous cement contains shell fragments and fine black grains. Some porosity in fossil molds

Silt, light olive-gray ( $5 Y 5 / 2)$, very fine sandy, clayey; with shell fragments and very fine black phosphatic (?) specks--_-_-_-

Sand, light olive-gray $(5 Y 5 / 2)$, very fine to fine, very clayey, calcareous in part, with very fine black phosphatic (?) specks; grading to -----_-

Clay, light olive-gray ( $5 Y 5 / 2)$, very fine sandy, calcareous in part---_---.--

Sand, light olive-gray $(5 Y 5 / 2)$, silt to very fine, clayey, sparsely glauconitic; grading to -

Clay, light olive-gray ( $5 Y 5 / 2)$, silty and sandy

Sand, pale brown (5YR 5/2), very fine to fine, very clayey; trace yellow-stained quartz pebbles-_-

Sand, pale brown ( $5 Y R 5 / 2)$, very fine to medium, predominantly very fine, subangular, very clayey; trace 1/2-in. subround quartz pebbles, trace fine white shell fragments -

Silt, pale brown ( $5 Y R 5 / 2)$, scattered very fine black specks--

Sand, pale brown (5 YR 5/2), silt to medium, predominantly very fine, subangular, with very fine black specks
Table 14. Interpretative lithologic description, Well DO-CE 88Continued

Lithology

Thickness Depth

(ft)

(ft)

Sand, pale brown (5YR 5/2), very fine to medium, predominantly medium, subangular, with black grains

Sand, pale brown $(5 Y R 5 / 2)$, very fine to coarse, predominantly medium, subangular -

Sand, pale brown ( $5 Y R 5 / 2)$, very fine to coarse, predominantly medium, becoming finer and clayey downward -_-_-_-_-

Sandstone, pale brown (5YR 5/2), very fine, weakly cemented, noncalcareous -

Sand, pale brown ( $5 Y R 5 / 2$ ), very fine, subangular, silty, with scattered black grains

Clay, pale brown (5YR 5/2), silty; interbedded with sand as above, trace white shell fragments

Silt, olive-gray $(5 Y 4 / 1)$, clayey

Eocene Series

Piney Point Formation

Sand, moderate brown ( $5 Y R 5 / 2$ ), very fine to medium, predominantly fine, angular to subangular, abundant greenish-black glauconite grains and trace of shell fragments

Shell fragments, white, probably with glauconite nodules and sand

Sand, moderate brown ( $5 Y R 5 / 2)$, very fine to medium, predominantly fine; interbedded with very fine clayey sand-

Ironstone, moderate brown (5YR 5/2) -----

Sand, moderate yellow-brown (10YR 5/4) with black specks, fine to coarse, predominantly medium, angular to subround, mostly quartz, with limonite and glauconite grains; trace of shell fragments -- ---

Sand as above; interbedded with gray-green $(5 G 5 / 2)$ silt

Nanjemoy Formation

Sand, moderate, yellow-brown (10YR 5/4), silt to very fine, clayey; interbedded with fine to coarse, poorly sorted sand; abundant glauconite nodules and traces of shell fragments

Sand, very fine to medium, predominantly fine, clayey, abundant glauconite ----

Clay, light olive-gray ( $5 Y 5 / 2)$, silty, very glauconitic-

Sand, dark yellow-brown (10YR 4/2), silt to very fine, quartz, subangular, clayey, 
Table 14. Interpretative lithologic description, Well DO-CE 88Continued

\begin{tabular}{ccc}
\hline Lithology & $\begin{array}{c}\text { Thickness } \\
\text { (ft) }\end{array}$ & $\begin{array}{c}\text { Depth } \\
(\mathrm{ft})\end{array}$ \\
\hline
\end{tabular}

glauconitic; interbedded with light olivegray $(5 Y 5 / 2)$, very glauconitic, silty clay with occasional shell fragments

Silt, gray-green ( $5 G 5 / 2)$, very glauconitic, with shell fragments and occasional quartz pebbles

Sand, very fine to fine, mostly composed of dark greenish-black glauconite grains, about 30 percent quartz

Sand as above; interbedded with gray-green $(5 G 5 / 2)$ silty clay; trace shell fragments --

Clay, gray-green, silty

Sand as in 640-650

\section{Paleacene (?) Series Aquia (?) Formation}

Sand, glauconite, as in 629-640 ft, with occasional thin layers of gray-green ( $5 G 5 / 2)$ silt

Silt, gray-green (5G 5/2), glauconitic; interbedded with greenish-gray ( $5 G 6 / 1)$ clay---

Clay, greenish-gray $(5 G Y 6 / 1)$ and light gray (5GY 8/1), silty, glauconitic, calcareous; with traces of very coarse angular quartz grains and shell fragments-

Sand, dusky brown (5YR 2/2), very fine, clayey, glauconitic, micaceous -_._-__-_

Clay as in 709-727 ft

Silt, greenish-gray (5GY 6/1), clayey, glauconitic, with trace of shell fragments - - -

Clay as in 709-727 ft; interbedded with very fine to fine glauconite sand

Sand, greenish-black, very fine to medium, mostly medium; mostly glauconite grains with a trace of coarse subangular quartz grains

Brightseat Formation

Clay, greenish-gray (5GY 6/1) and light green $(5 G Y 8 / 1)$, silty, calcareous, trace shell fragments -_____

Sand, greenish-black ( $5 G Y 2 / 1$ ), very fine to medium, predominantly fine, composed of polylobate glauconite-_-

\section{Cretaceous System \\ Upper Cretaceous Series \\ Severn and Matawan Formations, undifferentiated}

Sand, medium to very coarse, subangular to subround clear, rose, and orange-stained quartz mixed with glauconite grains as above and trace of shell fragments
Table 14. Interpretative lithologic description, Well DO-CE 88Continued

\begin{tabular}{ccc}
\hline Lithology & $\begin{array}{c}\text { Thickness } \\
\text { (ft) }\end{array}$ & $\begin{array}{c}\text { Depth } \\
\text { (ft) }\end{array}$ \\
\hline
\end{tabular}

Sand, greenish-black (5GY 2/1), fine, glauconite, clayey; interbedded with clay and

Magothy Formation

Sand, greenish-black ( $5 G Y 2 / 1)$, silt to medium, predominantly fine, about 60 percent glauconite, 40 percent quartz - -

Sandstone, dark yellowish-orange (10YR $6 / 6$ ), fine to medium, mostly quartz grains, some glauconite, calcareous -_____-__-

Sand, greenish-black ( $5 G Y 2 / 1)$, silt to medium, predominantly fine, 70 percent glauconite, 30 percent quartz, with a few very coarse quartz grains and shell fragments---

Clay, greenish-gray $(5 G 6 / 1)$, silty, with trace shell fragments and foraminifers --

Sand as above, with trace of shell fragments

Silt, grayish-green ( $5 G Y 5 / 2$ ), clayey, calcareous; grading to clay-_-__-_-_-_-

Sand, fine to coarse, predominantly medium, subangular clear and rose quartz with about 20 percent glauconite grains; with thin streaks of yellowish-gray ( $5 Y$ $7 / 2$ ), light brownish-gray (5YR 6/1), and greenish-gray ( $5 G Y 6 / 1)$ slightly calcareous clay; trace of shell fragments, foraminifers, and quartz pebbles-

Sand, very fine to very coarse, predominantly fine, with trace shell fragments-_Silt, greenish-gray $(5 G 6 / 1)$, clayey

Lower Cretaceous Series Potomac Group, undifferentiated

Silt, greenish-gray (5G 6/1), clayey; interbedded with very fine to very coarse, predominantly very fine sand

Sand, very fine to coarse, predominantly very fine to fine, subangular, mostly clear quartz-

Silt, greenish-gray $(5 G 6 / 1)$, clayey -_._._.

Sand, as above, with a few very coarse grains

Clay, yellowish-gray, $(5 Y 8 / 1)$

Sand, as in 1,034-1,044 ft

Clay, light brown (5YR 5/6); interbedded with sand as above

$\begin{array}{rr}10 & 1,044 \\ 6 & 1,050 \\ 11 & 1,061 \\ 6 & 1,067 \\ 5 & 1,072 \\ & \\ 11 & 1,083 \\ & \\ 11 & 1,094 \\ 6 & 1,100\end{array}$

Sand, very fine to very coarse, poorly sorted, subangular, clear to orange-stained quartz grains, slightly clayey -

Clay, light brown (5YR 5/6), sandy

(1)


Table 14. Interpretative lithologic description, Well DO-CE 88Continued

\begin{tabular}{lcc} 
Lithology & $\begin{array}{c}\text { Thickness } \\
(\mathrm{ft})\end{array}$ & $\begin{array}{c}\text { Depth } \\
(\mathrm{ft})\end{array}$ \\
\hline
\end{tabular}

Sand, as above, with thin streaks of clay as

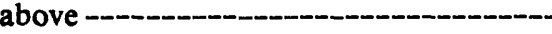

Sandstone, very fine grained, subangular;

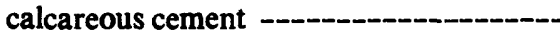

Clay, moderate olive-brown (5Y 4/4), with dark gray silty streaks, very plastic-...-...

Sand, very fine to coarse, poorly sorted, subangular quartz, with thin streaks of clay as above -

Sand, silt to very fine with trace very coarse subangular quartz grains, clayey; interbedded with pale greenish-yellow (10Y 8/2) and grayish-orange $(10 Y R 7 / 4)$ clay-..--.-

Sand, silt to medium, predominantly very fine to fine, subangular quartz, clear to partly iron-stained -...-..................

Clay, mottled light gray $(N 7)$ and moderate red-brown (10R 4/6); and moderate redbrown silt

Sand, very fine to medium, predominantly fine to medium, angular to subangular, mostly quartz, with some limonite grains; with occasional thin layers of very fine silty sand, silt, and clay

Sand, very fine to very coarse, predominantly medium, subangular; with occasional thin streaks of clay as above-_......

Sandstone, very fine to medium-grained, iron and calcareous cement-...............

Sand, very fine to very coarse, predominantly coarse, subangular, mostly quartz, some limonite

Clay, sandy

Sand, very fine to very coarse, predominantly medium

Clay, sandy

Sand, very fine to very coarse, predominantly fine to medium

Silt and clay

Sand, very fine to very coarse, predominantly

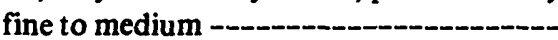

Sand, very fine to very coarse, predominantly fine to medium, clayey-

Sand, very fine to very coarse, predominantly fine to medium, clean, with trace of quartz pebbles-

Sand as above; interbedded with moderate yellow-brown (10YR 10/4) silt and moderate brown (5YR 4/4), light brown ( $5 Y$ $6 / 4)$, pale greenish-yellow (10Y 8/2), and greenish-gray $(5 G Y 6 / 1)$, silty, calcareous clay

Sand, very fine to very coarse, predominantly fine to medium, fairly clean -..........-

Sand as above; interbedded with varicolored

21,110

$2 \quad 1,112$

$21 \quad 1,133$
Table 14. Interpretative lithologic description, Well DO-CE 88Continued

Lithology

Thickness Depth (ft) (ft)

clay as in 1,431-1,459 and moderate yellowbrown (5YR 5/4) to moderate brown ( $5 Y R$ 4/4), iron-cemented siltstone ---.---.---

Sand, very fine to very coarse, predominantly fine to medium, subangular, with a few thin silty and clayey streaks-...-...-_-_-

Sand, as above but predominantly very fine, with silty and clayey streaks --.---.---.

Clay, pale greenish-yellow (10Y 8/2) and greenish-gray (5GY 6/1), silty--..-..-...--

Sand, very fine to very coarse, predominantly very fine

Clay, as above-

Sand, light brown (5YR 5/6), silt to very fine, clayey

1,192 Sand, very fine to very coarse, predominantly fine to medium, with thin clayey and silty streaks, trace of quartz pebbles

Sand, very fine to fine, clayey and silty ------

Sand, very fine to coarse, predominantly fine to medium; with thin layers of moderate brown $(5 Y R 4 / 4)$ iron-cemented siltstone-

Sand, very fine to fine, clayey and silty -----

Sand, very fine to coarse, predominantly fine to medium -

Sand, very fine to coarse, predominantly very fine to fine, silty

$5 \quad 1,308$ Clay, grayish-orange-pink (5YR 7/2) and moderate yellowish-brown (10YR 5/4),

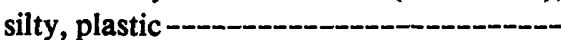

Sand, very fine to coarse, predominantly fine, slightly clayey-----.-----.---

Sand, very fine to coarse, predominantly very fine, silty, clayey -...-...-...-...-

Silt, light brown (5YR 5/6) -...-...-..-..--

Silt, moderate brown (5Y 4/4); interbedded with moderate brown and pale greenishyellow $(10 Y 8 / 2)$, silty, waxy clay and very clayey sand

Sand, very fine to coarse, predominantly very fine to fine, subangular --.---.--.--

$19 \quad 1,421$ Sand, very fine to coarse, predominantly fine to medium, angular to subangular, mostly quartz grains, and some limonite; with a few thin beds of light greenish-gray (5GY 8/1) clay and light brown (5YR 5/5), yellowish-gray $(5 Y 7 / 2)$, and grayish-green (10GY 10/2), iron- and silica-cemented siltstone

Sand, very fine to very coarse, predominantly medium, angular to subangular ----------

Sand as above; grading downward into pale olive $(10 Y 6 / 2)$ silt to very fine, clayey sand; interbedded with light greenish-gray
$82 \quad 1,790$

$10 \quad 1,800$

$20 \quad 1,820$

$20 \quad 1,840$

Hydrogeology 33 
Table 14. Interpretative lithologic description, Well DO-CE 88Continued

Lithology

Sand, very fine to very coarse, predominantly fine to medium; with 1-ft layer of siltstone, as in $1,800-1,820$, at $1,871 \mathrm{ft}$; trace lignite-_-_-_

Clay, moderate red $(5 R 4 / 6)$ and light greenish-gray ( $5 G 6 / 1)$; interbedded with very fine clayey sand; trace lignite -_...--

Sand, very fine to very coarse, predominantly fine, mostly clean but with clayey streaks, trace of lignite

Clay, olive-gray (5Y 3/2), yellowish-gray (5Y 7/2), partly with orange mottling, silty, partly micaceous, partly waxy; interbedded with grayish-olive ( $10 Y 4 / 2$ ), fine, clayey, micaceous sand and light brown (5YR 5/6) silt; trace of lignite--

Sand, very fine to coarse, predominantly fine, slightly clayey-_-_-

Clay, varicolored as in 1,916-1,955 ft, silty to sandy; interbedded with very fine clayey sand and silt

Sand, very fine to very coarse, predominantly fine to medium, fairly clean

Clay interbedded with silt -_-

Sand, very fine to very coarse, predominantly fine to medium, fairly clean -_-_-_-_-

Silt -

Sand, very fine to very coarse, predominantly medium, angular to subangular -_-_-_-_

Clay and silt, interbedded

Sand, as above

Silt, light brown (5YR 5/6), moderate brown (5YR 4/4) and grayish-brown (5YR 3/2); interbedded with moderate brown, grayishred-purple $(5 R P 6 / 2)$ and pale greenishyellow $(10 Y 8 / 2)$ clay. Clay increasing downward

Clay as above; interbedded with silt-_-_-_-_-

Sand, very fine to very coarse, predominantly very fine, clayey; interbedded with light brown (5YR 5/6) silt and clay

Clay, light brown (5YR 5/6), silty; interbedded with light brown silt and fine to medium clayey sand, with trace of subangular quartz pebbles

Sand, moderate brown (5YR 4/4), silt to medium, predominantly very fine, clayey, slightly calcareous -_-_._-_._-

Clay, pale yellow-brown (10YR 6/2), very silty and very fine sandy, slightly calcareous

Sand, grayish-green ( $5 G 5 / 2)$, with dark specks, very fine, clayey -__-_-

Sand, very fine to very coarse, predominantly
Table 14. Interpretative lithologic description, Well DO-CE 88Continued
Thickness Depth (ft) (ft)

$18 \quad 1,858$

$24 \quad 1,882$

$6 \quad 1,888$

28

1,916

39

1,955

$19 \quad 1,974$

$16 \quad 1,990$

$27 \quad 2,017$

$22 \quad 2,039$

$5 \quad 2,044$

$7 \quad 2,051$

$17 \quad 2,068$

$8 \quad 2,076$

$12 \quad 2,088$

$14 \quad 2,102$

$18 \quad 2,120$

$30 \quad 2,150$

$21 \quad 2,171$

22

2,193

$4 \quad 2,197$

$9 \quad 2,206$ medium to coarse, angular to subangular quartz-

Clay, pale yellow-brown (10YR 6/2), silty and sandy

Sand as above -

Clay, moderate reddish-brown (10R 4/6), moderate yellowish-brown (10YR 5/4), grayish yellowish-green ( $5 G Y 7 / 2)$, and dark greenish-gray ( $5 G 4 / 1)$, silty, sandy, slightly calcareous in part -_._-_._-

Sand, very fine to very coarse, predominantly medium to coarse, clayey -

Clay as above

Sand, very fine to very coarse, predominantly medium to coarse, angular to subangular, quartz, clean

Clay, light brown (5YR 5/6), grayish-green (10G 4/2), mottled greenish-gray ( $5 G Y$ $6 / 1)$, and dusky red (5R 3/4), silty, mostly non-calcareous, non-swelling - -

Silt, light brown (5YR 5/6)

Clay, dusky red (5R 3/4), dense, crumbly, and light brown (5YR 5/6), moderate brown (5YR 4/4), and light greenish-gray $(5 G 6 / 1)$, trace lignite and pyrite -..-_-

Sand, very fine to very coarse, predominantly coarse, subangular quartz, slightly clayey--

Clay, varicolored as in 2,318-2,339 ft; interbedded with very fine clayey sand and silt-_-_-_-_-_-

Sand, grayish-green $(5 G 5 / 2)$, very fine to fine, subangular, with very fine dark grains, slightly clayey

Sand, very fine to very coarsę, predominantly fine to medium, subangular -

Clay, sandy

Sand as above

Clay interbedded with silt -_.

Sand, grayish-green (10GY 5/2), fine, subangular with fine dark specks, slightly clayey, with clay laminae-

Clay, moderate brown (5YR 4/4), moderate orange-pink $(10 R \quad 7 / 4)$, pale greenishyellow $(10 Y 8 / 2)$, dark greenish-gray $(5 G Y$ $4 / 1$ ), and medium brown (5YR 3/4), locally mottled red, gray, and purple; with thin layers of fine to poorly sorted sand and yellow-gray $(5 Y 7 / 2)$, light brown (5YR 5/6), pale brown ( $5 Y R 5 / 2)$, and dusky yellow $(5 Y 6 / 4)$, slightly calcareous silt-_-_-_-_ 154

Sand, very fine to very coarse, predominantly medium to coarse, subangular, clean----

Clay, varicolored as in 2,494-2,648 ft; interbedded with moderate reddish-brown
6

2,212

$2 \quad 2,214$

$27 \quad 2,241$

12

$12 \quad 2,265$

$5 \quad 2,270$

30

2,300

$10 \quad 2,310$

$8 \quad 2,318$

21

2,339

17

2,356

60

2,416

10

2,426

10

2,436

2,438

$5 \quad 2,443$

$35 \quad 2,478$

16

2,494

$12 \quad 2,660$ 
Table 14. Interpretative lithologic description, Well DO-CE 88Continued

\begin{tabular}{ccc}
\hline Lithology & $\begin{array}{c}\text { Thickness } \\
\text { (ft) }\end{array}$ & $\begin{array}{c}\text { Depth } \\
\text { (ft) }\end{array}$ \\
\hline
\end{tabular}

$(10 R 4 / 6)$ silt

Sand, dark greenish-gray ( $5 G 4 / 1$ ), silt to very fine, clayey, very finely micaceous, fine lignitic particles, dense; with streaks varicolored clay and silt

Sand, very fine to very coarse, predominantly medium to coarse, subangular, clear to light bluish-gray ( $5 B 7 / 1)$, grayish-purple $(5 R B 4 / 2)$, and very pale orange (10YR 8/2) quartz grains -

Sand, predominantly very fine to medium, clayey, becoming finer and more clayey downward; interbedded with sandy clay and silt

Sand, very fine to fine, generally clean except for thin silty and clayey streaks - - -

Clay

Sand, very fine to very coarse, predominantly medium to coarse, generally clean except for a few thin silty and clayey streaks; trace lignite and quartz pebbles

Clay, interbedded with silt and clayey sand --

Silt, moderate brown (5YR 4/4) and dark greenish-gray, clayey, muscovitic, with black carbonaceous laminae-- - -

Sand, moderate yellow-brown (10YR 6/4), very fine, silty, clayey, with carbonaceous specks-_-_-_____

Silt, greenish-gray (5GY 6/1), slightly calcareous-

Sand, very fine to coarse, predominantly fine to medium, slightly clayey

Clay, pale green $(5 G 7 / 2)$ and moderate redorange $(10 R 6 / 6)$, swelling; interbedded with medium reddish-brown $(10 R \quad 4 / 6)$ and pale yellowish-brown (10YR 6/2) silt and medium yellowish-brown (10YR 5/4), very fine silty, clayey sand; trace of lignite

Sand, moderate yellow-brown (10YR 5/4), very fine to medium, predominantly very fine, silty, subangular

Clay, as in 2,945-2,973 ft; with thin layers of

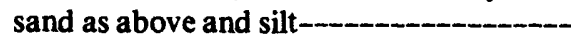

Sand, grayish-green ( $5 G 6 / 1)$, fine to medium, somewhat clayey -..._............

Clay, gray; interbedded with sand as above --

Sand, very fine to very coarse, predominantly medium, angular to subangular, becoming clayey downward
2,973

$25 \quad 2,710$

30

2,740

47

2,787

23

2,810

$6 \quad 2,816$

20

2,836

64

15

2,915

5

2,920

4

2,924

21

2,945

2,978

14

2,992

$15 \quad 3,007$

$3 \quad 3,010$

7

Table 14. Interpretative lithologic description, Well DO-CE 88Continued

$$
\text { Lithology }
$$

Thickness Depth

(ft) (ft)

Silt, moderate yellow-brown (10YR 5/4) and gray-green $(5 G 5 / 2)$, with trace of lignite --

Sand, very fine to very coarse, predominantly fine, slightly clayey, with trace of lignite---

Sand as above; interbedded with greenishgray $(5 G 6 / 1)$, grayish-green $(10 G Y 5 / 2)$, very pale green $(10 G 8 / 2)$, and light olivebrown (5Y 5/6), silty, slightly calcareous clay, and dark yellowish-green (10GY 4/4), sandy, slightly calcareous silt, with traces of lignite

Silt, light olive-gray (5 $Y 5 / 2)$, very fine sandy, clayey, calcareous -_-_-_-_-

Sand, dark greenish-gray ( $5 G Y 4 / 1)$ to olivegray (5Y $4 / 1)$, very fine, subangular, somewhat clayey, becoming increasingly clayey downward

Silt, light olive-gray ( $5 Y 5 / 2)$, very fine sandy, clayey, calcareous

Sand, very fine to very coarse, predominantly very fine to fine-

Sand, very fine to very coarse, predominantly fine to medium, angular to subangular quartz-_-_-_-_-

Silt, dusky yellowish-green (10GY 3/2), clayey, slightly calcareous, swells; with thin streaks of clay -

Sand, medium gray (N3), very fine to medium, predominantly fine, subangular quartz, with traces of muscovite and lignite, clean

Sand, very fine to very coarse, predominantly very fine to fine, angular to subangular quartz; with thin layers of silt and clay ---

Silt, dusky yellowish-green (10GY 3/2), clayey, slightly calcareous, swells --_--

Sand as in 3,218-3,236 ft-_.

Silt as in 3,236-3,258 ft

Sand, very fine to very coarse, predominantly fine to medium, angular to subangular quartz, clean

8

27

3,052

40

16

3,092

3,108

20

3,128

8

3,136

10

3,146

28

3,174

16

3,190

28

18

3,236

22

3,258

3,263

27

3,290

14

3,304

\section{Precambrian (?) basement}

Gneiss, quartz monzonite, biotitic

33

3,337

'Description from surface to $115 \mathrm{ft}$ based on driller's log adjusted to U.S. Geological Survey gamma-ray log.

${ }^{2}$ Colors described from wet samples. Code from Geological Society of America, 1948. 
Table 15. Transmissivities, hydraulic conductivities and intrinsic permeabilities based on aquifer-test analyses

\begin{tabular}{|c|c|c|c|c|c|}
\hline Date of test & $\begin{array}{l}\text { Perforated interval } \\
\text { (feet below KB)' }\end{array}$ & $\mathrm{T}^{2}$ & $K_{h^{3}}$ & $k^{4}$ & Remarks \\
\hline $2 / 28 / 81 \ldots$ & $3,188-3,218^{5}$ & 380 & 12.5 & 4 & $\begin{array}{l}\text { Temperature corrected for brackish water; Cooper and } \\
\text { Jacob (1946), straight-line analyses; } T=29.9^{\circ} \mathrm{C} \text {. }\end{array}$ \\
\hline 3/31/81 & $2,834-2,844$ & $275-300$ & $27-30$ & 9 & $\begin{array}{l}\text { Temperature corrected. Specific capacity at } t=452 \mathrm{~min} \text {; } \\
\mathrm{T}=38.3^{\circ} \mathrm{C} \text {. }\end{array}$ \\
\hline 4/16/81 - & $2,649-2,655.6$ & 525 & 75 & 18 & $\begin{array}{l}\text { Temperature corrected. Specific capacity at } t=240 \mathrm{~min} \text {; } \\
\mathrm{T}=38.0^{\circ} \mathrm{C} \text {. }\end{array}$ \\
\hline $5 / 28 / 81 \ldots$ & $2,278.4-2,288.4$ & 850 & 85 & 23 & $\begin{array}{l}\text { Temperature corrected. Specific capacity at } t=217 \text { min; } \\
T=34.0^{\circ} \mathrm{C} \text {. }\end{array}$ \\
\hline 7/31/81 & $1,422.4-1,432.4$ & 25 & 2.5 & 0.8 & $\begin{array}{l}\text { No temperature correction required. Specific capacity at } \\
t=152 \text { min and straight line analyses (Cooper and Jacob, } \\
\text { 1946); } T=25.5^{\circ} \mathrm{C} \text {. }\end{array}$ \\
\hline
\end{tabular}

'Kelly bushing datum (KB) is $9.42 \mathrm{ft}$ above sea level and $5 \mathrm{ft}$ above land surface.

${ }^{2}$ Transmissivity, in feet squared per day.

${ }^{3}$ Horizontal hydraulic conductivity, in feet per day.

'Intrinsic permeability, in micrometers squared. Viscosity of pure water used for all tests except the February 28, 1981, test. The dynamic viscosity used for that test was $.8647 \mathrm{cP}$ (centipoises) at $29.9^{\circ} \mathrm{C}$.

'Screened interval.

\section{Heads}

Heads were measured at seven depths. Table 16 lists point-water heads, environmental heads, and freshwater heads. Lusczynski (1961) defines the various heads that can be used to represent pressure conditions in ground waters of variable density. "Point-water head" is generally defined as the water level, relative to a given datum, in a piezometer (a tightly cased well used to measure hydraulic head at a point) filled with water from the zone tapped by the piezometer. "Freshwater head" is the water level in a piezometer filled with freshwater. If the water in the aquifer were fresh, the point-water and freshwater heads would be identical. "Environmental- water having the same depth-integrated density as the water head" is the water level in a piezometer filled with column of ground water in the saturated section penetrated by the piezometer. Freshwater heads are useful in determining the rate and direction of horizontal groundwater flow, whereas environmental heads are useful for analyzing vertical flow.

Figure 9 shows the vertical distribution of pointwater heads, environmental heads, freshwater heads, and fluid densities. The vertical profile of environmental heads shows a generalized vertical hydraulic gradient that is causing an upward component of ground-water flow. The upward movement of ground water may be a natural component of the regional prepumping flow

Table 16. Summary of fluid-head measurements

\begin{tabular}{|c|c|c|c|c|c|c|}
\hline Date & $\begin{array}{c}\text { Perforation interval } \\
\text { (ft) below KB' }\end{array}$ & $\begin{array}{l}\text { Measuring } \\
\text { point (ft) } \\
\text { relative to sl }\end{array}$ & $\begin{array}{l}\text { Point-water } \\
\text { heads (ft) } \\
\text { relative to KB }\end{array}$ & $\begin{array}{l}\text { Point-water } \\
\text { heads (ft) } \\
\text { relative to sl }\end{array}$ & $\begin{array}{l}\text { Environmental- } \\
\text { water heads (ft) } \\
\text { relative to } \mathrm{s}^{2}\end{array}$ & $\begin{array}{c}\begin{array}{c}\text { Freshwater heads } \\
\text { (ft) }\end{array} \\
\text { relative to } \mathrm{sl}^{\mathbf{3}} \\
\end{array}$ \\
\hline 2/27/81--- 1215 & $3,188-3,218$ & 9.52 & -63.17 & -53.75 & +44.16 & +53.22 \\
\hline 3/25/81—- 0857 & $2,834-2,844$ & 6.35 & +18.64 & +28.06 & +40.11 & +42.38 \\
\hline 4/16/81---- & $2,649-2,655.6$ & 7.05 & +25.52 & +34.94 & $\begin{array}{l}\text { Approximately } \\
\text { equal to point- } \\
\text { water head }\end{array}$ & $\begin{array}{l}\text { Approximately } \\
\text { equal to point- } \\
\text { water head }\end{array}$ \\
\hline 5/27/81-- About 1800 & $2,278.4-2,288.4$ & do & +11.53 & +20.95 & do & do. \\
\hline $6 / 23 / 81 \ldots$ & $1,822.4-1,832.4$ & do & +5.13 & +14.55 & do & do. \\
\hline 7/27/81- - & $1,469.4-1,479.4$ & do & -25.50 & -16.08 & do & do. \\
\hline 7/31/81-- - 0915 & $1,422.4-1,432.4$ & do & -27.75 & -18.33 & do & do. \\
\hline
\end{tabular}

'Kelly bushing datum (KB) is $9.42 \mathrm{ft}$ above sea level (sl), or $5 \mathrm{ft}$ above land surface.

${ }^{2}$ Environmental-water heads are not compensated for an increasing temperature with depth. Heads would further increase with depth if the temperature compensation were incorporated.

${ }^{3}$ Freshwater heads computed using density of $0.998 \mathrm{~g} / \mathrm{ml}$ at $20^{\circ} \mathrm{C}$. This density was measured for water from the $1,422.4-1,432.4 \mathrm{ft}$ perforation interval. 


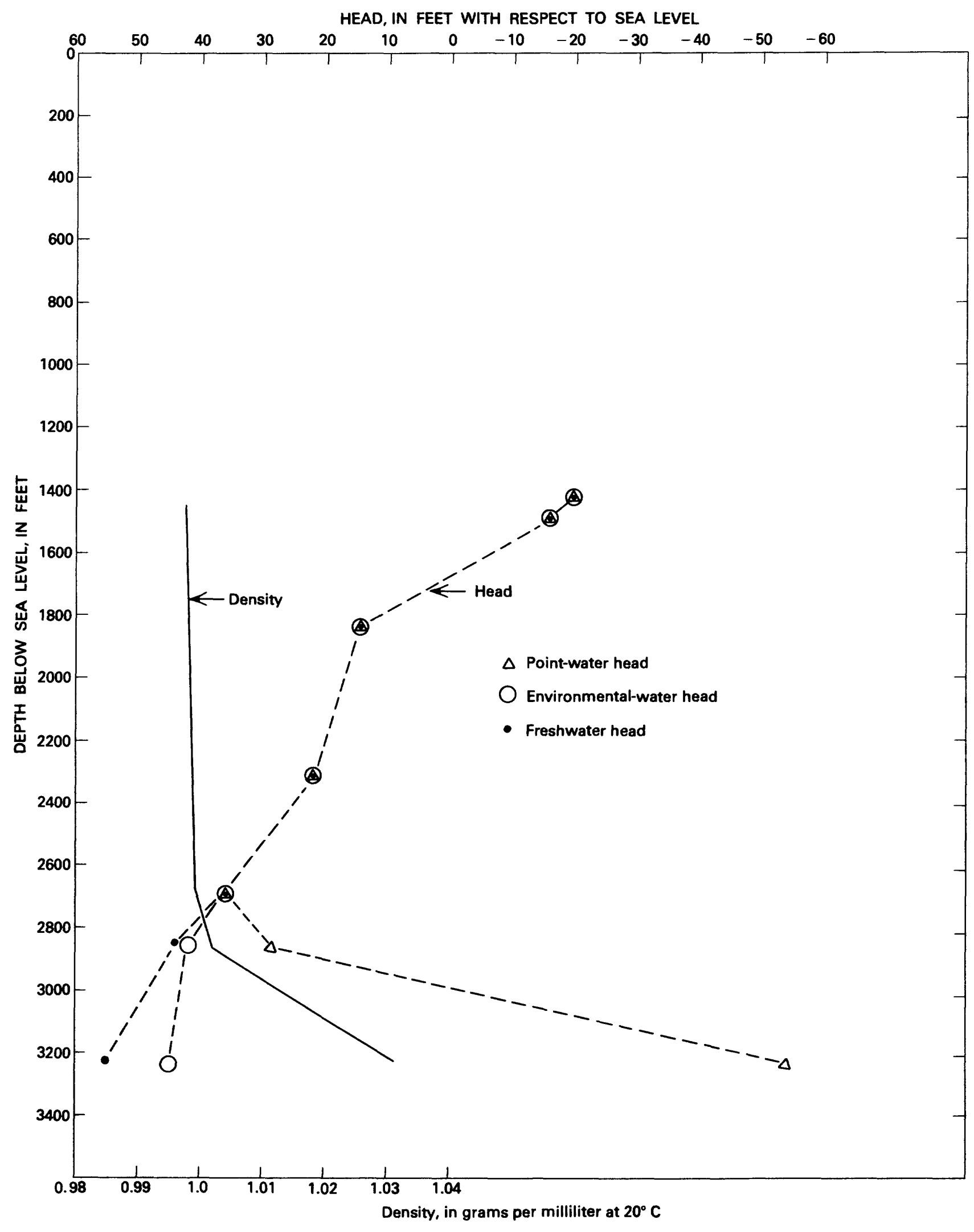

Figure 9. Head and density profile. 
Table 17. Principal dissolved chemical constituents of water samples from cores in U.S. Geological Survey test well DO-CE 88 and of selected other samples

\begin{tabular}{|c|c|c|c|c|c|c|c|}
\hline $\begin{array}{l}\text { Depth (ft below kelly bushing } \\
\text { in DO-CE 88; in other wells, } \\
\text { reported depth in ft) }\end{array}$ & $\begin{array}{c}\text { Calcium } \\
\text { (mg/L as Ca) }\end{array}$ & $\begin{array}{l}\text { Magnesium } \\
\text { (mg/L as Mg) }\end{array}$ & $\begin{array}{l}\text { Lithium } \\
\text { (ug/L as } L \text { ) }\end{array}$ & $\begin{array}{c}\text { Sodium } \\
\text { (mg/L as } \mathrm{Na} \text { ) }\end{array}$ & $\begin{array}{c}\text { Silica } \\
\left(\mathrm{mg} / \mathrm{L} \text { as } \mathrm{SiO}_{2}\right)\end{array}$ & $\begin{array}{c}\text { Sulfate } \\
\left.(\mathrm{mg} / \mathrm{L} \text { as SO})_{4}\right)\end{array}$ & $\begin{array}{c}\text { Chloride } \\
\text { (mg/h as Cl) }\end{array}$ \\
\hline $139--$ & 48 & 26 & 50 & 310 & 48 & 66 & 160 \\
\hline 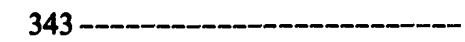 & 41 & 21 & 20 & 190 & 46 & 68 & 99 \\
\hline $397^{1}$ & $4.0^{1}$ & $3.4^{1}$ & $\ldots$ & $177^{1}$ & $20^{1}$ & $11^{1}$ & $5.1^{1}$ \\
\hline 592 & 12 & 1.9 & 20 & 280 & 34 & 71 & 90 \\
\hline $732 \ldots$ & 3.2 & 2.3 & 20 & 290 & 16 & 57 & 54 \\
\hline $955^{1} \ldots$ & $3.2^{1}$ & $2.4^{1}$ & -- & $139^{1}$ & $18^{1}$ & $14^{1}$ & $6.8^{1}$ \\
\hline $1,113 \ldots$ & 12 & 1.9 & 20 & 200 & 11 & 80 & 100 \\
\hline $1,333^{1}$ & $0.4^{1}$ & $0.1^{1}$ & -- & $57^{1}$ & $12^{1}$ & $18^{1}$ & $1.7^{1}$ \\
\hline $1,423^{2}$ & $0.6^{2}$ & $0.5^{2}$ & --- & $95^{2}$ & $14^{2}$ & $16^{2}$ & $2.3^{2}$ \\
\hline $1,438 \ldots$ & 11 & 1.3 & $<20$ & 170 & 17 & 56 & 79 \\
\hline -_-_-_-_-_- & 8.6 & 0.1 & $<60$ & 180 & 17 & 26 & 50 \\
\hline $1,823^{2}$ & $1.5^{2}$ & $0.6^{2}$ & $\ldots$ & $240^{2}$ & $15^{2}$ & $35^{2}$ & $2.8^{2}$ \\
\hline 1,952 & 5.3 & 1.9 & $<20$ & 300 & 47 & 47 & 30 \\
\hline $2,094 \ldots$ & 15 & 2.7 & $<100$ & 230 & 12 & 110 & 57 \\
\hline $2,203 \ldots$ & 48 & 23 & $<60$ & 960 & 7.4 & 1,400 & 230 \\
\hline $2,279^{2}$ & $2^{2}$ & $0.4^{2}$ & -- & $260^{2}$ & $18^{2}$ & $35^{2}$ & $120^{2}$ \\
\hline 2,319 & 36 & 21 & $<80$ & 660 & 10 & 490 & 280 \\
\hline $2,425 \ldots$ & 11 & 1.3 & $<60$ & 270 & 8.1 & 150 & 28 \\
\hline do --.-- & 4.6 & 3.5 & $<20$ & 400 & 110 & 130 & 28 \\
\hline $2,484 \ldots$ & 9.4 & 4.6 & $<50$ & 430 & 22 & 330 & 62 \\
\hline $2,649^{2}$ & $1.1^{2}$ & $0.4^{2}$ & - & $230^{2}$ & $19^{2}$ & $28^{2}$ & $140^{2}$ \\
\hline 2,694 $\ldots$ & 16 & 3.5 & $<100$ & 570 & 3.8 & 230 & 440 \\
\hline 2,695 & 6.9 & 0.3 & $<60$ & 480 & 93 & 74 & 360 \\
\hline $2,823 \ldots$ & 73 & 10 & $<80$ & 1,200 & 17 & 370 & 1,200 \\
\hline $2,834^{2}-\cdots$ & $44^{2}$ & $7.7^{2}$ & -- & $1,400^{2}$ & $19^{2}$ & $38^{2}$ & $2,200^{2}$ \\
\hline $2,900 \ldots$ & 1,000 & 180 & $<600$ & 6,300 & 1.3 & 860 & 10,000 \\
\hline do --. & --- & --- & -- & -- & -- & 720 & 11,000 \\
\hline 3,010 & 1,300 & 200 & 200 & 7,600 & 1.1 & 660 & 12,000 \\
\hline do --.-- & -- & -- & -- & -- & -- & 310 & 17,000 \\
\hline 3,110 & 2,000 & 350 & 500 & 11,000 & 7.7 & 390 & 18,000 \\
\hline do --.-- & $\ldots$ & --- & --- & -- & -- & 360 & \\
\hline $3,188^{2}-$ & $2,900^{2}$ & $490^{2}$ & -- & $14,000^{2}$ & $14^{2}$ & $665^{2}$ & $27,800^{2}$ \\
\hline 3,210 & 2,100 & 320 & 900 & 9,500 & 3.8 & 460 & 18,000 \\
\hline 3,210_-_-_-_-_- & 2,200 & 400 & 2,000 & 9,100 & 5.5 & 200 & 18,000 \\
\hline 3,336 - & -- & -- & - & - & -- & - & 6,600 \\
\hline do - & -- & -- & -- & -- & -- & -- & 7,100 \\
\hline
\end{tabular}

'Analyses from wellhead water samples from nearby wells; shown for comparison with core samples from DO-CE 88.

${ }^{2}$ Analyses of wellhead water samples from DO-CE 88; shown for comparison with core samples.

system, or it may be, in part, induced by the withdrawal of ground water from shallower aquifers in the Cambridge area.

A continuous water-level recorder monitored water levels in the 3,188- to 3,218-ft screened zone March 4-7, 1981. During this period, tidal fluctuations of approximately $0.8 \mathrm{ft}$ were observed in the well, with peaks about every 12.5 hours. In addition, the observed water level responded to longer term changes in atmospheric pressure.

\section{GEOCHEMISTRY}

\section{Water Analyses}

Water samples for chemical analysis were obtained from two principal sources: water that flowed or was pumped from screened or perforated zones (wellhead samples) and water from cores. 


\section{Water from Cores}

Water samples were squeezed from sediment cores in a stainless steel hydraulic squeezer described by Manheim (1966, p. C256-C260). The chemical analyses are given in table 17. Generally, 25 to 50 grams of sediment, obtained from the inner part of the core (to lessen the possibility of contamination from drilling fluid), were placed in the squeezer. Pressures used to extract the interstitial water ranged from about 4,000 to 20,000 $\mathrm{lb} / \mathrm{in}^{2}$. The lower pressures were adequate to squeeze water from cores obtained at depths of less than $1,700 \mathrm{ft}$ and from the sandy cores at any depth. The higher pressures were required for the deeper, nonsandy materials. Water samples ranged in volume from about $0.5 \mathrm{~mL}$ to more than $3 \mathrm{~mL}$, the shallower and sandier materials generally yielding more water. Analyses were performed in the U.S. Geological Survey National Water Quality Laboratory, Atlanta, Ga., using ion chromatography and argon plasma emission spectrometry.

Chloride concentrations of interstitial water were determined from basement cores obtained at $3,336 \mathrm{ft}$ (Manheim, F. T., 1982, written commun.). Nine grams of the inner part of the core were ground to submicron size in a tungsten carbide mill, diluted with 70 grams of distilled water, and centrifuged in an ultra centrifuge at $40,000 \mathrm{rpm}$ for up to 1 hour. Analyses were performed at the Branch of Atlantic-Gulf of Mexico Geology, Woods Hole, Mass., using a Coulometric Buchler chloridometer.

The zone of transition from freshwater downward to saltwater that is roughly equivalent to seawater, as indicated by chloride concentrations in both the squeezed and wellhead samples (also shown in table 17), occurs between 2,650 and 3,100 ft. In this zone and in the highly saline zone below, the water is principally of a sodium chloride character (terminology of Back, 1966), although significant concentrations of calcium occur below 2,900 $\mathrm{ft}$. In the freshwater section, above $2,650 \mathrm{ft}$, the water is of a sodium bicarbonate character in the wellhead samples and probably in all but one of the squeezed samples. However, the squeezed samples from 2,094 to $2,900 \mathrm{ft}$ contain much higher concentrations of sulfate than do wellhead samples from similar depths. Also, concentrations of calcium, magnesium, sodium, and, most notably, chloride in the freshwater section are generally higher in the squeezed samples than in the wellhead samples.

\section{Water Produced from Well}

Wellhead samples from six zones were analyzed by the U.S. Geological Survey National Water Quality Laboratory in Atlanta. The samples were collected after the specific conductance, temperature, and $\mathrm{pH}$ of the water pumped or flowing from the well had stabilized. Standard U.S. Geological Survey techniques were used to collect the water samples; temperature, $\mathrm{pH}$, specific conductance, and alkalinity were measured in the field.

Table 18 shows the results of the analyses for the six zones sampled. The variation of concentration with depth is shown graphically in figure 10 for the major cations and in figure 11 for the major anions and silica. Three additional chemical analyses from nearby wells (DO-CE 2, DO-CE 3, DO-CE 82), which were screened

Table 18. Chemical analyses of wellhead water samples

\begin{tabular}{|c|c|c|c|c|c|c|}
\hline \multirow[b]{2}{*}{ Parameter } & \multicolumn{6}{|c|}{ Depth to top of sampled interval below kelly-bushing, in feet ${ }^{1}$} \\
\hline & 1423 & 1823 & 2279 & 2649 & 2834 & 3188 \\
\hline $\begin{array}{l}\text { Date } \\
\text { Time }\end{array}$ & $\begin{array}{c}7 / 31 / 81 \\
1200\end{array}$ & $\begin{array}{c}6 / 23 / 81 \\
0900\end{array}$ & $\begin{array}{c}5 / 28 / 81 \\
1345\end{array}$ & $\begin{array}{c}4 / 16 / 81 \\
1900\end{array}$ & $\begin{array}{c}3 / 26 / 81 \\
1330\end{array}$ & $\begin{array}{c}2 / 28 / 81 \\
1745\end{array}$ \\
\hline Geologic unit code en-- $^{2}$ & 217 PPSC & 217 PPSC & 217 ARDL & 217 ARDL & 217 PTXN & 217 PTXN \\
\hline Discharge, gal/min----- & 7 & 10 & 52 & 57 & 30 & 32 \\
\hline Temperature, ${ }^{\circ} \mathrm{C}-$ & 22.5 & 21.5 & 33.0 & 37.0 & 34.0 & 35.5 \\
\hline Specific conductance, field ${ }^{3}-$ & 410 & 760 & 996 & 920 & 6,500 & 58,500 \\
\hline Specific conductance, lab ${ }^{3}$ & 394 & 828 & 1,060 & 1,010 & 7,250 & 64,300 \\
\hline Density, g/mL- & .998 & .999 & .999 & 1.000 & 1.003 & 1.032 \\
\hline Field pH, units - & 8.5 & 8.6 & 8.4 & 8.7 & 7.8 & 7.6 \\
\hline Lab pH, units - & 8.5 & 8.5 & 8.6 & 8.8 & 8.2 & 6.2 \\
\hline Saturation index (calcite) - & -.89 & -.13 & -.13 & -.12 & .15 & .74 \\
\hline Turbidity ${ }^{4}-$ & 200 & 260 & .65 & 4.6 & 7.1 & .00 \\
\hline Calcium, dissolved --_--- & .6 & 1.5 & 2.0 & 1.1 & 44 & 2,900 \\
\hline Magnesium, dissolved -- & .5 & .6 & .4 & .4 & 7.7 & 490 \\
\hline Potassium, dissolved - & 5.0 & 3.5 & 1.9 & 1.5 & 8.9 & 48 \\
\hline Sodium, dissolved--_- & 95 & 240 & 260 & 230 & 1,400 & 14,000 \\
\hline Alkalinity (as $\left.\mathrm{CaCO}_{3}\right)$, dissolved ${ }^{3}-$ & 172 & 425 & 341 & 276 & 150 & 48 \\
\hline Sulfate, dissolved - & 16 & 35 & 35 & 28 & 38 & 665 \\
\hline
\end{tabular}

See footnotes at end of table. 
Table 18. Chemical analyses of wellhead water samples-Continued

\begin{tabular}{|c|c|c|c|c|c|c|}
\hline \multirow[b]{2}{*}{ Parameter } & \multicolumn{6}{|c|}{ Depth to top of sampled interval below kelly-bushing, in feet' } \\
\hline & 1423 & 1823 & 2279 & 2649 & 2834 & 3188 \\
\hline $\begin{array}{l}\text { Date } \\
\text { Time } \\
\end{array}$ & $\begin{array}{c}7 / 31 / 81 \\
1200 \\
\end{array}$ & $\begin{array}{c}6 / 23 / 81 \\
0900\end{array}$ & $\begin{array}{c}5 / 28 / 81 \\
1345 \\
\end{array}$ & $\begin{array}{c}4 / 16 / 81 \\
1900 \\
\end{array}$ & $\begin{array}{c}3 / 26 / 81 \\
1330 \\
\end{array}$ & $\begin{array}{c}2 / 28 / 81 \\
1745\end{array}$ \\
\hline Chloride, dissolved--- & 2.3 & 2.8 & 120 & 140 & 2,200 & 27,800 \\
\hline Fluoride, dissolved -..- & 1.4 & 2.3 & 1.3 & 1.0 & .4 & .3 \\
\hline Silica, dissolved-__________ & 14 & 15 & 18 & 19 & 19 & 14 \\
\hline Phosphorus (as P), dissolved-_- & .21 & - & .13 & - & - & - \\
\hline Phosphorus (as P), total - & .69 & - & .11 & - & - & - \\
\hline Nitrogen, ammonia (as N), dissolved-_____-_ & .05 & - & .09 & - & - & - \\
\hline Nitrogen, ammonia (as N), total-___ & .60 & - & .08 & - & - & - \\
\hline Solids, residue at $180^{\circ} \mathrm{C}$, dissolved & 255 & 575 & 631 & 594 & 3,910 & 45,500 \\
\hline Solids, sum of constituents, dissolved & 250 & 560 & 637 & 596 & 3,820 & 47,200 \\
\hline Hardness (as $\left.\mathrm{CaCO}_{3}\right)$ & 4 & 6 & 7 & 4 & 140 & 9,300 \\
\hline Aluminum, dissolved ${ }^{6}$ & 120 & 410 & 10 & 70 & 30 & 10 \\
\hline Arsenic, dissolved ${ }^{6}$ & 1 & 1 & 1 & 0 & $\mathbf{0}$ & 1 \\
\hline Arsenic, suspended ${ }^{6}$ & 0 & 8 & 1 & 0 & $\mathbf{0}$ & 0 \\
\hline Barium, dissolved ${ }^{6}$-_-__ & 30 & 50 & 40 & 20 & 400 & - \\
\hline Barium, suspended ${ }^{6}$ & 400 & 300 & 60 & 80 & $\mathbf{0}$ & - \\
\hline Boron, dissolved ${ }^{6}$ & 400 & 780 & 360 & 400 & 560 & - \\
\hline Bromide, dissolved -______ & .018 & .016 & .8 & .9 & 19 & - \\
\hline Cadmium, dissolved ${ }^{6}$ & 1 & 2 & $<1$ & 1 & 1 & 0 \\
\hline Cadmium, suspended 6 & 0 & - & - & 0 & 2 & 0 \\
\hline Chromium, dissolved ${ }^{6}$ & 10 & $<10$ & 20 & 10 & 20 & 50 \\
\hline Chromium, suspended ${ }^{6}--$ & 210 & - & $\mathbf{0}$ & 10 & 10 & $\mathbf{0}$ \\
\hline Cobalt, dissolved ${ }^{6}$ & $<1$ & $<1$ & 2 & 4 & 1 & 1 \\
\hline Cobalt, suspended ${ }^{6}-$ & - & - & $\mathbf{0}$ & 0 & $\mathbf{0}$ & $\mathbf{0}$ \\
\hline Copper, dissolved ${ }^{6}$ & 2 & 2 & 1 & 0 & 0 & 2 \\
\hline Copper, suspended ${ }^{6}$ & 68 & 150 & 5 & 2 & 1 & 0 \\
\hline Iron, dissolved 6 & 350 & 140 & 310 & 100 & 710 & 7,200 \\
\hline Iron, suspended ${ }^{6}$ & 48,000 & 39,000 & 130 & 1,300 & 1,100 & 5,800 \\
\hline Lead, dissolved ${ }^{6}$ & 6 & 1 & $\mathbf{0}$ & 1 & $\mathbf{0}$ & 0 \\
\hline Lead, suspended ${ }^{6}$ & 22 & 32 & 1 & 1 & 1 & 11 \\
\hline Manganese, dissolved ${ }^{6}$ & 7 & 20 & 30 & 10 & 280 & 8,600 \\
\hline Manganese, suspended ${ }^{6}$ & 410 & 470 & 0 & 20 & $\mathbf{0}$ & 400 \\
\hline Mercury, dissolved 6 & $<.1$ & .2 & .2 & .3 & 1.4 & 3.0 \\
\hline Mercury, suspended ${ }^{6}$ & - & .2 & .0 & .1 & .8 & .0 \\
\hline Nickel, dissolved $^{6}$-_- & $<1$ & 2 & 1 & 0 & 0 & 1 \\
\hline Nickel, suspended ${ }^{6}$ & - & 47 & 9 & 8 & 9 & 2 \\
\hline Potassium 40 (as K40), dissolved'- & 3.7 & - & 1.4 & 1.1 & 6.6 & 37 \\
\hline Selenium, dissolved ${ }^{6}$ & $<1$ & $<1$ & 0 & 0 & $\mathbf{0}$ & 0 \\
\hline Selenium, suspended 6 & - & - & 0 & 0 & 0 & 0 \\
\hline Silver, dissolved ${ }^{6}-\ldots$ & $<1$ & $<1$ & 0 & 0 & 0 & $\mathbf{0}$ \\
\hline Silver, suspended ${ }^{6} \ldots$ & - & - & 0 & 0 & $\mathbf{0}$ & 0 \\
\hline Sodium adsorption ratio - - & 22 & 46 & 44 & 48 & 51 & 63 \\
\hline Sodium percent --_- & 95 & 98 & 98 & 99 & 95 & 77 \\
\hline Zinc, dissolved ${ }^{6}-$ & 10 & $<4$ & $<4$ & $<4$ & 10 & 40 \\
\hline Zinc, suspended 6 - & 100 & - & - & - & 20 & 200 \\
\hline
\end{tabular}

'Concentrations in milligrams per liter unless otherwise indicated.

2217 PPSC designates Patapsco Fm., 217 PTXN designates Patuxent Fm. and 217 ARDL designates Arundel Fm.; upper, lower, and middle parts, respectively, of the Potomac Group.

${ }^{3}$ Micromhos per centimeter at $25^{\circ} \mathrm{C}$.

'Nephelometric turbidity units.

${ }^{\text {s}}$ Field measurement.

'Micrograms per liter. One milligram equals 1,000 micrograms.

'Picocuries per liter. 


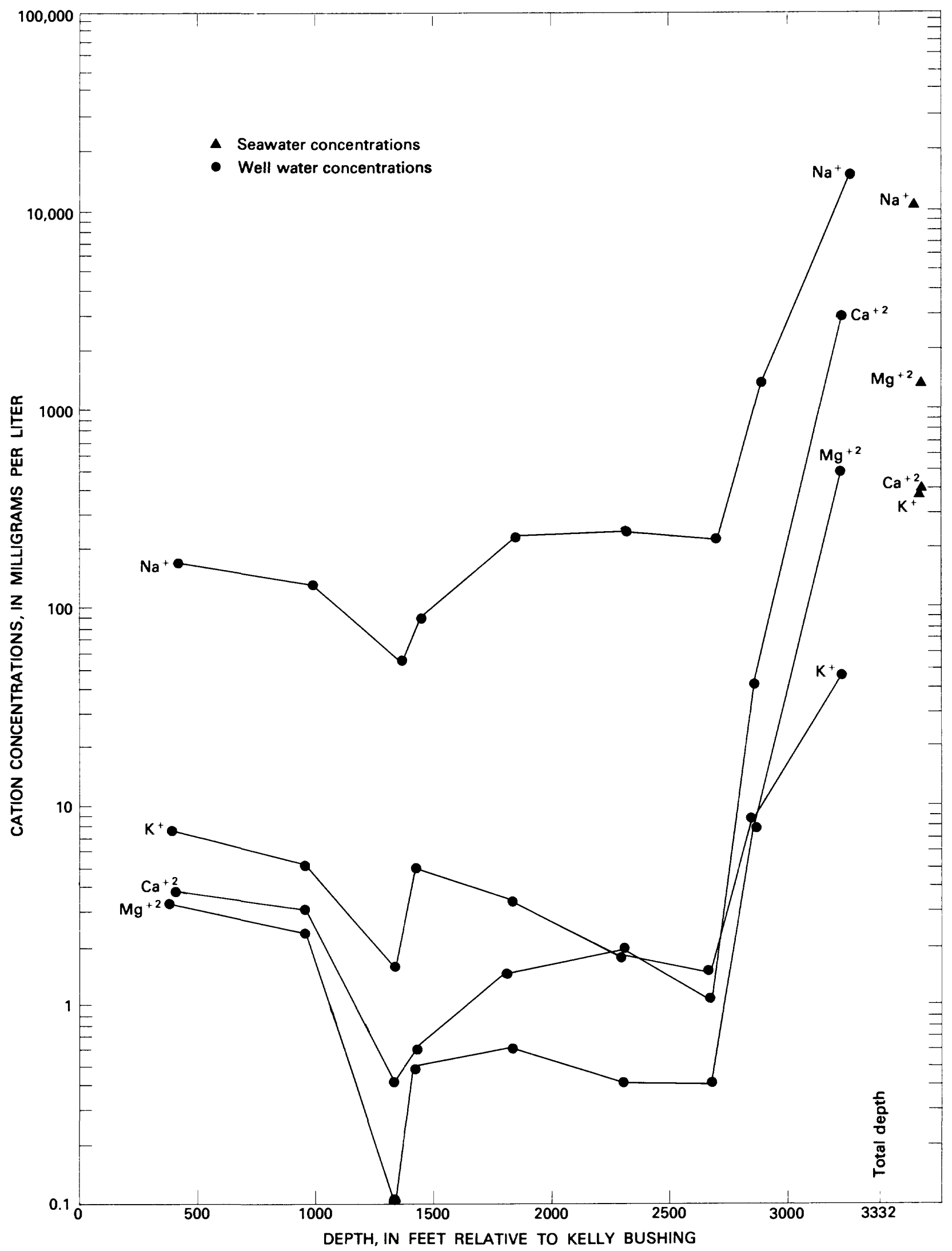

Figure 10. Variation in concentration of major cations with depth. 


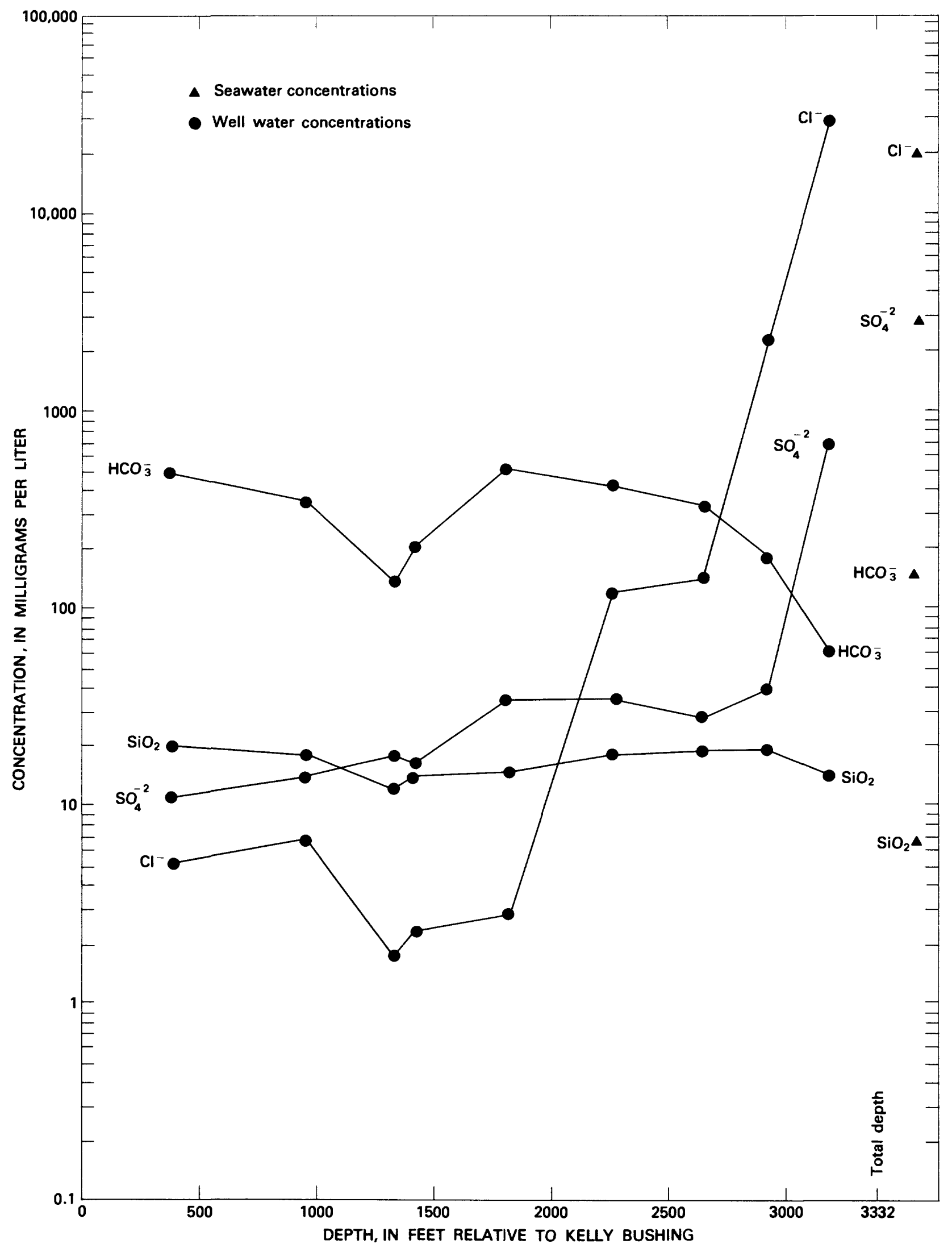

Figure 11. Variation in concentration of major anions and silica with depth. 
at shallower depths (Woll, 1978), are included in figures 10 and 11. Seawater concentrations (Hem, 1970, p. 11) are also plotted for comparison.

As shown in figure 10 , calcium $\left(\mathrm{Ca}^{+2}\right)$ and magnesium $\left(\mathrm{Mg}^{+2}\right)$ decrease in concentration by about an order of magnitude between 397 and 1,333 ft. Potassium $\left(\mathrm{K}^{+}\right)$and sodium $\left(\mathrm{Na}^{+}\right)$decrease, but by less than an order of magnitude. From 1,333 to $1,418 \mathrm{ft}$, the concentrations of the ions increase to levels somewhat lower than in the sample at $397 \mathrm{ft}$. Between 2,649 and 3,188 ft, the concentrations of the cations increase sharply to their maximum levels. The water at $3,188 \mathrm{ft}$ is a brine having total dissolved solids concentration 1.4 times that of seawater. The concentrations of $\mathrm{Na}^{+}$and $\mathrm{Ca}{ }^{+2}$ are higher in the brine sample than in seawater, whereas the concentrations of $\mathrm{Mg}^{+2}$ and $\mathrm{K}^{+}$are lower.

Figure 11 shows that chloride $\left(\mathrm{Cl}^{-}\right)$and sulfate $\left(\mathrm{SO}_{4}^{-2}\right)$ concentrations vary with depth in a manner roughly similar to that of the cations. Alkalinity (as $\mathrm{HCO}_{3}^{-}$) concentrations vary with depth in a manner nearly identical to that of $\mathrm{Na}^{+}$in the freshwater section above 2,649 ft. However, beginning at 2,649 ft, alkalinity decreases sharply downward to a minimum at 3,188 ft. Silica $\left(\mathrm{SiO}_{2}\right)$ concentrations are relatively constant in the freshwater section and somewhat higher than seawater. Alkalinity and $\mathrm{SO}_{4}^{-2}$ concentrations in the brine at $3,188 \mathrm{ft}$ are lower and the $\mathrm{Cl}^{-}$and $\mathrm{SiO}_{2}$ concentrations are higher than in seawater.

Figure 12 is a diagram showing the hydrochemical facies of the test-well water samples and of the three analyses reported by Woll (1978). The diagram is of a type originated by Durov (1948) and described by Zaporozec (1972). The Durov diagram permits the plotting of two parameters in addition to relative concentrations of common ions. In figure 12, these parameters are depth relative to kelly bushing and the saturation index (SI) of the water with respect to calcite.

Figure 12 indicates that the cation facies is of the sodium type while the anion facies is of either the bicarbonate type or the chloride type. Combination of the cation and anion facies indicates water of a sodium bicarbonate character or a sodium chloride character. The figure also shows that the ground water changes progressively with depth from a sodium bicarbonate character to a sodium chloride character.

SI was determined for the analyses by the computer program WATEQF (Plummer and others, 1976) and is defined as

$$
\text { SI }=\log \frac{\text { IAP }}{\mathrm{K}} \text {, }
$$

where IAP = ion activity product and $\mathrm{K}=$ the equilibrium constant for the reaction.
An SI of 0 indicates that the water is in equilibrium with respect to a reaction. A negative SI indicates that the water is undersaturated, and a positive SI indicates that the water is supersaturated.

The saturation indices indicate that the analyses from the freshwater section are undersaturated (negative) with respect to calcite $\left(\mathrm{CaCO}_{3}\right)$. The more negative a number, the more undersaturated the water. The most undersaturated water is at $1,333 \mathrm{ft}$, which corresponds to the abrupt decrease in concentrations of $\mathrm{Ca}^{+2}$ and $\mathrm{HCO}_{3}^{-}$shown on figure 10 and figure 11 , respectively. The two analyses from deeper saline sections are supersaturated with respect to $\mathrm{CaCO}_{3}$. The saturation indices for the wellhead samples are also given in table 16.

\section{Cation Exchange Capacities and Concentrations of Exchangeable Cations}

Samples of 20 cores were analyzed for cation exchange capacities (CEC), by means of standard techniques (Hesse, 1972), at the U.S. Geological Survey National Water Quality Laboratory in Denver. The CEC of colloidal material is defined by Van Olphen (1963) as the excess of counter ions (ions on the surface of a colloidal particle) in the zone adjacent to the charged surface or layer that can be exchanged for other cations. CEC is normally expressed as the number of milliequivalents of cations that can be exchanged per 100 grams of dry sample $(\mathrm{meq} / 100 \mathrm{~g})$. The results of the cation exchange capacity analyses are listed in table 19 for triplicate samples.

Table 19. Cation exchange capacities from core samples, in milliequivalents per 100 grams

\begin{tabular}{|c|c|c|c|c|}
\hline Depth' & Primary & Duplicate & Triplicate & Mean \\
\hline $130-$ & 12.4 & 9.6 & 12.0 & 11.3 \\
\hline $340-$ & 26.4 & 26.4 & 24.0 & 25.6 \\
\hline $590 \ldots$ & 29.6 & 24.8 & 32.8 & 29.1 \\
\hline $730-$ & 28.0 & 23.2 & 27.2 & 26.1 \\
\hline $863-$ & 18.4 & 16.4 & 16.0 & 16.9 \\
\hline $912-$ & 16.0 & 11.6 & 15.2 & 14.3 \\
\hline 1,111 & 13.6 & 12.4 & 16.4 & 14.1 \\
\hline 1,436 & 14.4 & 11.2 & 12.0 & 12.5 \\
\hline 1,650 & 21.6 & 20.0 & 24.0 & 21.9 \\
\hline 1,753 & 16.4 & 14.4 & 10.4 & 13.7 \\
\hline 1,950 & 31.2 & 28.0 & 28.4 & 29.2 \\
\hline 2,094 & 22.4 & 20.0 & 23.2 & 21.9 \\
\hline $2,200 \ldots$ & 21.6 & 20.0 & 20.8 & 20.8 \\
\hline 2,319 & 34.4 & 32.8 & 35.2 & 34.1 \\
\hline 2,422 & 16.8 & 13.6 & 17.2 & 15.9 \\
\hline 2,484 & 16.0 & 13.6 & 18.4 & 16.0 \\
\hline 2,585 & 37.6 & 37.6 & 41.6 & 38.9 \\
\hline 2,692 & 20.8 & 16.4 & 16.8 & 18.0 \\
\hline 3,008 & 14.4 & 11.2 & 13.6 & 13.1 \\
\hline 3,210 & 8.0 & 7.2 & 9.6 & 8.3 \\
\hline
\end{tabular}

'Feet below kelly bushing. 


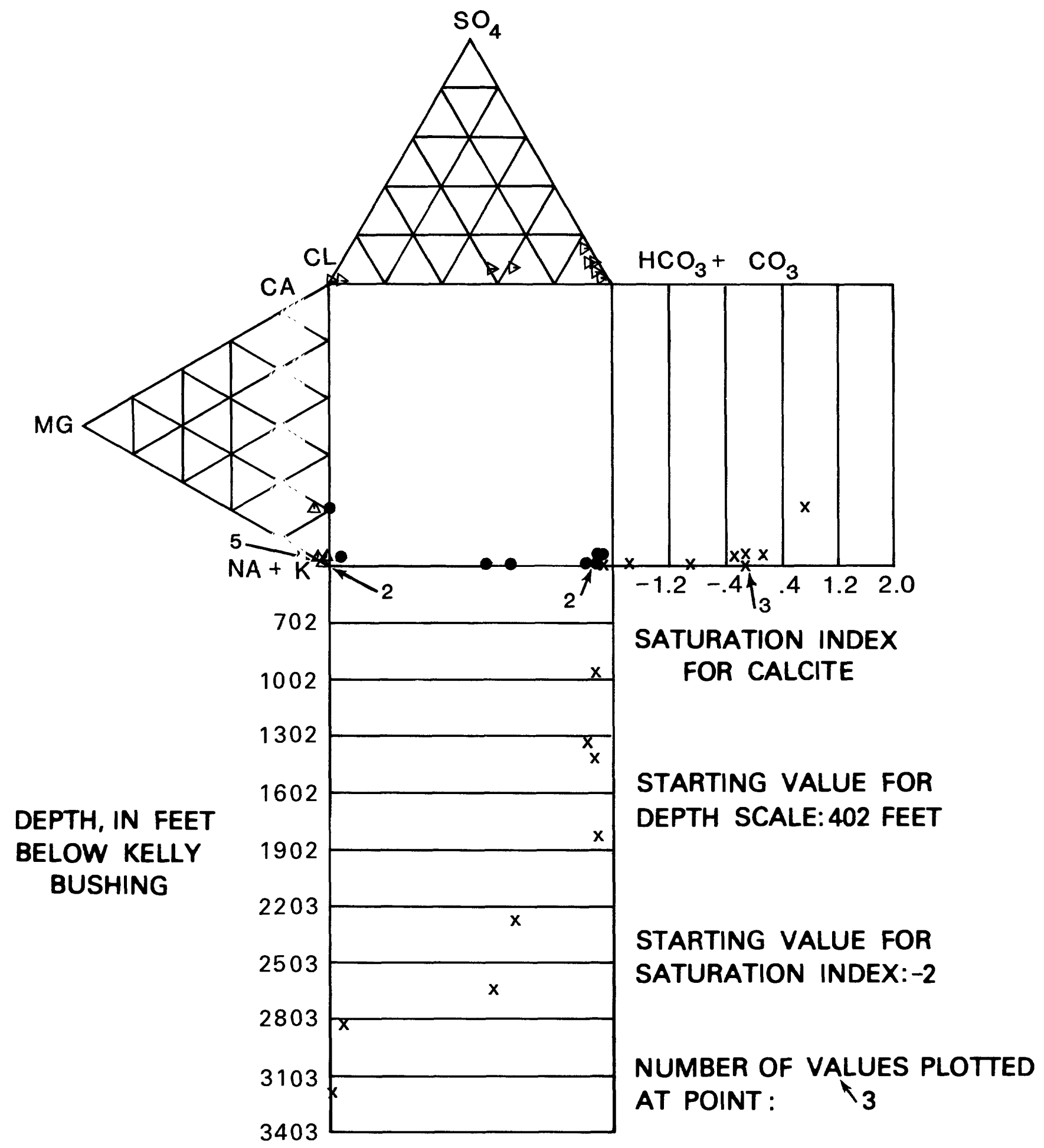

Figure 12. The hydrochemical facies of ground water from test well DO-CE 88 and other nearby wells.

The same samples were also analyzed for concentrations of exchangeable cations. Exchangeable cations are cations that can be expected to enter or leave the layer of counter ions on the colloidal surface. The samples were successively leached three times with ammonium acetate buffer. The leachates were then analyzed by atomic absorption spectrophotometry for calcium, magnesium, potassium, and sodium (Delora Boyle, U.S. Geological Survey, written commun., October 23, 1981). Table 20 shows the exchangeable cations in milligrams per gram $(\mathrm{mg} / \mathrm{g})$ for duplicate samples.

The data in table 20 were converted to millimoles 
Table 20. Exchangeable cations from core samples, in milligrams per gram

\begin{tabular}{|c|c|c|c|c|c|c|c|c|c|c|c|c|}
\hline \multirow[b]{2}{*}{ Depth' } & \multicolumn{3}{|c|}{ Calcium } & \multicolumn{3}{|c|}{ Magnesium } & \multicolumn{3}{|c|}{ Potassium } & \multicolumn{3}{|c|}{ Sodium } \\
\hline & Primary & Duplicate & Mean & Primary & Duplicate & Mean & Primary & Duplicate & Mean & Primary & Duplicate & Mean \\
\hline $130 \ldots$ & 2.85 & 2.70 & 2.78 & .80 & .86 & .83 & .33 & .32 & .33 & .34 & .35 & .35 \\
\hline 340 & 10.35 & 10.75 & 10.55 & 2.33 & 2.61 & 2.47 & 1.17 & 1.38 & 1.28 & 1.06 & 1.08 & 1.07 \\
\hline 590 & 45.00 & 58.50 & 51.75 & 1.25 & 1.61 & 1.43 & 7.99 & 6.97 & 7.48 & 5.04 & 5.22 & 5.13 \\
\hline 730 & 22.80 & 24.20 & 23.50 & 1.22 & 1.32 & 1.27 & 2.91 & 2.79 & 2.85 & 2.60 & 2.31 & 2.46 \\
\hline $863-$ & 8.95 & 8.85 & 8.90 & 1.24 & 1.49 & 1.37 & 1.11 & 1.24 & 1.18 & 1.52 & 1.47 & 1.50 \\
\hline $912-$ & 2.28 & 2.64 & 2.46 & 1.25 & 1.46 & 1.36 & .35 & .42 & .39 & .93 & .94 & .94 \\
\hline $1,111 \ldots$ & 1.74 & 2.32 & 2.03 & .69 & .82 & .76 & .62 & .65 & .64 & .90 & .89 & .90 \\
\hline $1,436 \ldots$ & 1.05 & 1.10 & 1.08 & .47 & .59 & .53 & .37 & .44 & .41 & .89 & .89 & .89 \\
\hline 1,650 & 2.31 & 2.42 & 2.37 & .87 & .95 & .91 & .48 & .62 & .55 & 2.59 & 2.34 & 2.47 \\
\hline $1,753 \ldots$ & 1.27 & 1.36 & 1.32 & .61 & .69 & .65 & .33 & .39 & .36 & 1.66 & 1.56 & 1.61 \\
\hline $1,950 \ldots$ & 3.05 & 3.02 & 3.04 & 1.22 & 1.38 & 1.30 & .49 & .62 & .56 & 4.27 & 4.43 & 4.35 \\
\hline $2,094 \ldots$ & 2.74 & 2.49 & 2.62 & .70 & .77 & .74 & .50 & .50 & .50 & 1.79 & 2.24 & 2.02 \\
\hline $2,200 \ldots$ & 2.50 & 2.89 & 2.70 & .71 & .73 & .72 & .33 & .42 & .38 & 3.14 & 2.75 & 2.95 \\
\hline $2,319 \ldots$ & 4.65 & 4.97 & 4.81 & .95 & 1.12 & 1.04 & .51 & .56 & .54 & 4.46 & 5.65 & 5.06 \\
\hline $2,422 \ldots$ & 1.61 & 1.54 & 1.58 & .41 & .47 & .44 & .22 & .32 & .27 & 1.86 & 1.78 & 1.82 \\
\hline $2,484 \ldots$ & 1.61 & 1.73 & 1.67 & .41 & .53 & .47 & .24 & .32 & .28 & 1.66 & 1.52 & 1.59 \\
\hline 2,585 & 4.56 & 5.18 & 4.87 & .92 & 1.16 & 1.04 & .48 & .53 & .51 & 4.46 & 5.15 & 4.81 \\
\hline 2,692 & 1.65 & 1.81 & 1.73 & .53 & .65 & .59 & .20 & .32 & .26 & 1.53 & 1.48 & 1.51 \\
\hline 3,008 & 1.76 & 1.85 & 1.81 & .19 & .24 & .22 & .25 & .35 & .30 & 2.82 & 2.37 & 2.60 \\
\hline 3,210 & 1.24 & 1.29 & 1.27 & .17 & .21 & .19 & .09 & .20 & .15 & 1.89 & 1.44 & 1.67 \\
\hline
\end{tabular}

'Feet below kelly bushing.

per 20 grams and plotted in figure 13 to show the variations with depth for the exchangeable cations. Also plotted in figure 13 are the mean CEC data given in table 19.

\section{SUMMARY AND CONCLUSIONS}

Test well DO-CE 88 penetrated 3,299 ft of Quaternary, Tertiary, and Cretaceous unconsolidated Coastal Plain sediments, chiefly clay and sand, and $33 \mathrm{ft}$ of quartz monzonite gneiss bedrock. Twenty-one core samples were collected to determine interstitial water chemistry, mineralogy, lithology, hydraulic properties, paleontologic age, and cation exchange properties. In addition, six sand zones were tested for aquifer properties and sampled to determine ground-water chemistry. Point-water heads were measured at seven depths. A temperature log showed a maximum temperature of $41.9^{\circ} \mathrm{C}$ and a mean temperature gradient of $0.00838^{\circ} \mathrm{C} / \mathrm{ft}$.

The analyses of water samples indicate that the zone of freshwater-saltwater transition occurs between 2,650 and 3,100 ft. Also, the ground water changes progressively with depth from a sodium bicarbonate to a sodium chloride character.

Most of the clays in the analyzed core samples belong to the montmorillonite group. However, the clays in the Upper Cretaceous Magothy Formation and the upper third of the Lower Cretaceous Potomac Group, undifferentiated, belong predominately to the kaolinite group. Mean cation exchange capacity ranged from $\mathbf{8 . 3}$ to $38.9 \mathrm{meq} / 100 \mathrm{~g}$ in core samples.

Vertical and horizontal hydraulic conductivities measured in cores ranged from $1.5 \times 10^{-6}$ to $1.3 \mathrm{ft} / \mathrm{d}$ and from $7.3 \times 10^{-6}$ to $1.3 \mathrm{ft} / \mathrm{d}$, respectively, but the most permeable sands were not cored. Porosity was 1.5 percent in the quartz monzonite bedrock and ranged from 22.4 to 41 percent in the overlying sediments.

Fossils identified in core samples include palynomorphs, dinoflagellates, and foraminifers.

In aquifer tests of five zones between depths of 1,422 and $3,218 \mathrm{ft}$, transmissivities ranged from 25 to $850 \mathrm{ft}^{2} / \mathrm{d}$, horizontal hydraulic conductivities ranged from 2.5 to $85 \mathrm{ft} / \mathrm{d}$, and intrinsic permeabilities ranged from 0.8 to $23(\mu \mathrm{m})^{2}$. Observed water levels used to analyze the aquifer tests were corrected for increasing water temperature. The increasing temperature caused the density of the water in the well to decrease during discharge.

Calculated environmental heads ranged from -18.33 to $+44.16 \mathrm{ft}$ relative to sea level, indicating an upward component of flow. This upward movement of water may be a natural component of the regional prepumping flow system, or it may be, in part, induced by withdrawal of ground water from shallower aquifers.

\section{SELECTED REFERENCES}

Abbott, W. H., 1978, Correlation and zonation of Miocene strata along the Atlantic margin of North America using diatoms and silicoflagellates: Marine Micropaleontology, v. 3, p. 15-34.

Armentrout, J. A., and Abbott, W. H., eds., North American Cenozoic biostratigraphy, symposium volume: Elsevier Press (in press).

Back, William, 1966, Hydrochemical facies and ground-water flow patterns in northern part of Atlantic Coastal Plain: U.S. Geological Survey Professional Paper 498-A, 42 p. 


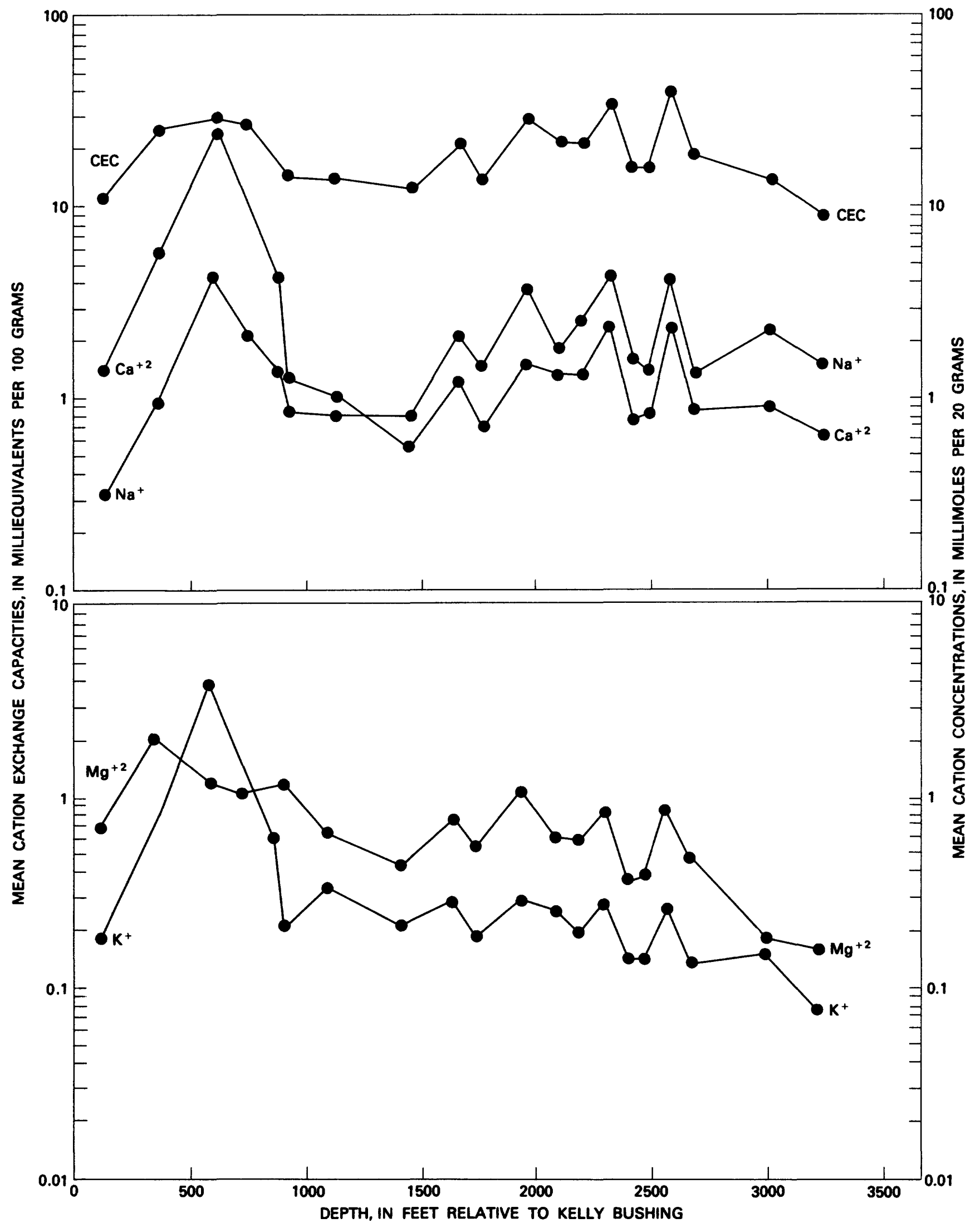

Figure 13. Cation exchange capacities and exchangeable cation concentrations. 
Bebout, J. W., 1980, Observed stratigraphic distribution of spores, pollen, and Incertae Sedis palynomorphs in the Tertiary section of the COST No. B-2 well, Baltimore Canyon, Atlantic Outer Continental Shelf: Palynology, v. 4, p. 181-196.

Bredehoeft, J. D., 1965, The drill-stem test: The petroleum industry's deep-well pumping test: Ground Water, v. 3, no. 3, p. 31-36.

Brenner, G. J., 1963, The spores and pollen of the Potomac Group of Maryland: Maryland Department of Geology, Mines and Water Resources Bulletin, v. 27, 215 p.

Brown, R. H., 1963, Estimating the transmissivity of an artesian aquifer from the specific capacity of a well, in Bentall, Ray, compiler, Methods of determining permeability, transmissibility and drawdown: U.S. Geological Survey Water-Supply Paper 1536-I, p. 336-338.

Christopher, R. A., 1979, Normapolles and triporate pollen assemblages from the Raritan and Magothy Formations (Upper Cretaceous) of New Jersey: Palynology, v. 3, p. 73-121.

Cooper, H. H., Jr., and Jacob, C. E., 1946, A generalized graphical method for evaluating formation constants and summarizing well-field history: American Geophysical Union Transactions, v. 27, no. 4, p. 526-534.

Cushing, E. M., Kantrowitz, I. H., and Taylor, K. R., 1973, Water resources of the Delmarva Peninsula: U.S. Geological Survey Professional Paper 822, 58 p., 12 pl.

Dörhøfer, Gunter, 1977, Palynologie und Stratigraphie der Bukeberg-Formation (Berriasium-Valanginium) in der Hilsmulde (NW-Deutschland): Geologische Jahrbuch, ser. A, no. 42 , p. 3-122, 15 pls., 8 figs., 3 tabs.

Doyle, J. A., and Robbins, E. A., 1977, Angiosperm pollen zonation of the continental Cretaceous of the Atlantic Coastal Plain and its application to deep wells in the Salisbury Embayment: American Association of Stratigraphic Palynologists, Inc., 8th annual meeting, Houston, 1975, Proceedings, v. 1, Palynology, p. 43-78.

Durov, S. A., 1948, Klassifikacija prirodnych vod i graficeskoje izobrazenie ich sostava. [Classification of natural waters and graphic representation of their composition]: Doklady Ak. Nauk SSSR, v. 59, no. 1, p. 87-90.

Freeze, R. A., and Cherry, J. A., 1979, Groundwater: Englewood Cliffs, N.J., Prentice-Hall, 604 p.

Geological Society of America, 1948, Rock color chart: Reprinted 1963, The Netherlands, Huyskes-Enschede.

Gibson, T. G., and others, 1980, Biostratigraphy of the Tertiary strata of the core, in Geology of the Oak Grove core: Virginia Division of Mineral Resources Publication 20, pt. 2, 88 p.

Hansen, Harry J., 1978, Upper Cretaceous (Senonian) and Paleocene (Danian) pinchouts on the south flank of the Salisbury Embayment, Maryland, and their relationship to antecedent basement structures: Maryland Geological Survey Report of Investigations, no. 29, 36 p.

1981, Stratigraphic discussion in support of a major unconformity separating the Columbia Group from the underlying upper Miocene aquifer complex in eastern Maryland: Southeastern Geology, v. 22, no. 3, p. 123-137.

Hem, J. D., 1970, Study and interpretation of the chemical characteristics of natural water, 2 nd ed.: U.S. Geological
Survey Water-Supply Paper 1473, 363 p.

Hesse, P. R., 1972, A textbook of soil chemical analysis: New York, Chemical Publishing Co., 520 p.

Hughes, N. F., and Croxton, C. A., 1973, Palynologic correlation of the Dorset “Wealden": Paleontology, v. 16, no. 3, p. 567-601.

INTERCOMP Resource Development and Engineering, Inc., 1976, A model for calculating effects of liquid waste disposal in deep saline aquifers: U.S. Geological Survey Water-Resources Investigations 76-61, $252 \mathrm{p}$.

Krumbein, W. C., and Pettijohn, F. J., 1938, Manual of sedimentary petrography: New York, London, AppletonCentury-Crofts, 549 p.

Lohman, S. W., 1972, Ground-water hydraulics: U.S. Geological Survey Professional Paper 708, 69 p., 9 pl.

Lusczynski, N. J., 1961, Head and flow of ground water of variable density: Journal of Geophysical Research, v. 66, no. 12 , p. 4247-4256.

Mack, F. K., Webb, W. E., and Gardner, R. A., 1971, Water resources of Dorchester and Talbot Counties, Maryland, with special emphasis on the ground-water potential of the Cambridge and Easton areas: Maryland Geological Survey Report of Investigations, no. 17, 107 p.

Manheim, F. T., 1966, A hydraulic squeezer for obtaining interstitial water from consolidated and unconsolidated sediments, in Geological Survey Research 1966: U.S. Geological Survey Professional Paper 550-C, C256-C261.

Plummer, L. N., Jones, B. F., and Truesdell, A. H., 1976, WATEQF-A FORTRAN IV version of WATEQ, a computer program for calculating chemical equilibrium of natural waters: U.S. Geological Survey Water Resources Investigations 76-13, 61 p. (Reprinted 1978).

Reinhardt, Juergen, Christopher, R. A., and Owens, J. P., 1980, Lower Cretaceous stratigraphy of the core, in Geology of the Oak Grove core: Virginia Division of Mineral Resources Publication 20, pt. 3, 88 p.

Reinhardt, Juergen, Newell, W. L., and Mixon, R. B., 1980, Tertiary lithostratigraphy of the core, in Geology of the Oak Grove core, Virginia Division of Mineral Resources Publication 20, pt. 1, 88 p.

Schlumberger Limited, 1972, Log interpretation principles: New York, $113 \mathrm{p}$.

1977, Log interpretation, charts: New York, 83 p.

Shattuck, G. B., 1904, Geologic and paleontologic relations with a review of earlier investigations, in Clark, W. B., Shattuck, G. B., and Dall, W. H., eds., The Miocene deposits of Maryland: Maryland Geological Survey, Miocene Volume, p. xxxiii-xciv.

Van Olphen, H., 1963, An introduction to colloid chemistry: New York, Wiley Interscience, $301 \mathrm{p}$.

Wolfe, J. A., and Pakiser, H. M., 1971, Stratigraphic interpretations of some Cretaceous microfossil floras of the Middle Atlantic States, in Geological Survey Research 1971: U.S. Geological Survey Professional Paper 750, p. B35-B47.

Woll, R. S., 1978, Maryland ground-water information: Chemical quality data: Maryland Geological Survey Water Resources Basic-Data Report, no. 10, 126 p.

Zaporozec, Alexander, 1972, Graphical interpretation of water quality data: Ground Water, no. 10, p. 32-43. 

in. (inch)
in. (inch)
ft (foot)
$\mathrm{ft} / \mathrm{d}$ (feet per day)
$\mathrm{ft}^{2} / \mathrm{d}$ (feet squared per day)
$\mathrm{lb} / \mathrm{in}^{2}$ (pounds per square inch)
$\mathrm{gal} / \mathrm{min}$ (gallons per minute)

$\mathrm{mm}$ (millimeter)
A (angstrom units)
$\mathrm{m}$ (meter)
$\mathrm{m} / \mathrm{s}$ (meters per second)
$\mathrm{m}^{2} / \mathrm{s}$ (meters squared per second)
$\mathrm{Pa}$ (pascals)
L/s (liters per second)

sl (sea level)

KB (kelly-bushing)
National Geodetic Vertical Datum of 1929 (NGVD of 1929): A geodetic datum derived from a general adjustment of the first-order level nets of both the United States and Canada, formerly called mean sea level.

$9.42 \mathrm{ft}$ above sl or $5 \mathrm{ft}$ above land surface 